Supporting Information

Page S1

\title{
Carbon-Silicon Bond Formation in the Synthesis of Benzylic Silanes
}

\author{
Michael D. Visco, Joshua M. Wieting, and Anita E. Mattson* \\ Department of Chemistry and Biochemistry, The Ohio State University, Columbus, Ohio 43210, United States
}

Table of Contents

1. General methods

S1

2. Synthesis of arylchlorosilanes

S2-S5

3. Synthesis of BINOL-based benzylic halides (Compounds 2, SI-17, SI-18)

S6-S8

4. Synthesis of 1a via silyl lithium addition (Scheme 2c)

S9

5. Products of Barbier-type coupling (Compounds 1a-1i)

S9-S12

6. Further reactions of selected benzyl silanes

$\mathrm{S} 13$

7. References

S14

8. Selected NMR spectra

S15-S55

General Methods: Diethyl ether, tetrahydrofuran, methylene chloride, and toluene were purified by passage through a bed of activated alumina. $\mathrm{CHCl}_{3}$ was purchased from Aldrich and used as received. Methanol was freshly distilled from $\mathrm{CaH}_{2}$. Purification of reaction products was carried out by flash chromatography using SiliaFlash P60 from Silylcycle (40$63 \mu \mathrm{m})$. Analytical thin layer chromatography was performed on EMD Chemicals $0.25 \mathrm{~mm}$ silica gel $60-\mathrm{F}_{254}$ plates. Visualization was accomplished with UV light and ceric ammonium molybdate stain followed by heating. Melting points (mp) were obtained on a Fisher Scientific Mel-Temp apparatus and are uncorrected. Infrared spectra (IR) were obtained on a Thermo Scientific Nicolet iS5 with an iD7 diamond ATR attachment and are uncorrected. Proton nuclear magnetic resonances ( ${ }^{1} \mathbf{H}$ NMR) were recorded in deuterated solvents on a Bruker Avance DPX $400(400 \mathrm{MHz})$ spectrometer. Chemical shifts are reported in parts per million (ppm, $\delta)$ using the solvent as internal standard $\left(\mathrm{CHCl}_{3}, \delta 7.26\right.$ and $\mathrm{C}_{6} \mathrm{D}_{6}, \delta$ 7.16). ${ }^{1} \mathrm{H}$ NMR splitting patterns are designated as singlet (s), doublet (d), triplet (t), or quartet (q). Splitting patterns that could not be interpreted or easily visualized are given as ranges of chemical shifts, or designated as multiplet $(\mathrm{m})$ or broad (br) when appropriate. Coupling constants are reported in Hertz $(\mathrm{Hz})$. Proton-decoupled carbon $\left({ }^{13} \mathrm{C}\right.$ NMR) spectra were recorded on a Bruker Avance DPX $400(100 \mathrm{MHz})$ spectrometer and are reported in ppm using the solvent as an internal standard $\left(\mathrm{CHCl}_{3}, \delta 77.16 ; \mathrm{C}_{6} \mathrm{D}_{6}, \delta\right.$ 128.1). Electrospray mass spectra (ESI-MS) were obtained using a Bruker MicrOTOF Mass Spectrometer. Unless otherwise noted, all other commercially available reagents and solvents were used without further purification. 
Supporting Information

Page S2

\section{Synthesis of chloro(4-methoxyphenyl)silane (SI-3):}<smiles>COc1ccc([N+](=O)Br)cc1</smiles>

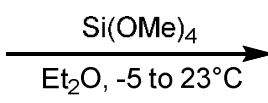<smiles>COc1ccc([SiH2]C)cc1</smiles>

SI-1

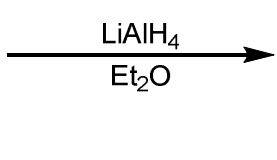<smiles>COc1ccc(S)cc1</smiles><smiles>C[13CH3]</smiles>

SI-2<smiles>COc1ccc([SiH2]Cl)cc1</smiles>

SI-3<smiles>COc1ccc(OC)cc1</smiles>

trimethoxy(4-methoxyphenyl)silane (SI-1) ${ }^{1}$ : To a flame dried 2-neck round bottom flask equipped with a water-cooled condenser was added magnesium turnings (532 mg, $22 \mathrm{mmol}$, 1.1 equiv.), which were freshly washed with $1 \mathrm{M} \mathrm{HCl}$ in methanol, three iodine crystals and $\mathrm{Et}_{2} \mathrm{O}(20 \mathrm{~mL})$. 4-bromoanisole $(2.50 \mathrm{~mL}, 20 \mathrm{mmol}, 1.0$ equiv.) was added slowly over the course of 45 minutes to the refluxing mixture of $\mathrm{Et}_{2} \mathrm{O}$ and magnesium turnings. After complete addition of 4-bromoanisole, the mixture was refluxed for an additional hour. The resulting Grignard reagent was cooled to $23{ }^{\circ} \mathrm{C}$ and added slowly to a solution containing $\mathrm{Si}(\mathrm{OMe})_{4}(8.84 \mathrm{~mL}, 60$ mmol, 3.0 equiv.) and $\mathrm{Et}_{2} \mathrm{O}(30 \mathrm{~mL})$ at $-5{ }^{\circ} \mathrm{C}$. The resulting mixture was then warmed to $23^{\circ} \mathrm{C}$ and stirred overnight. The reaction mixture was diluted with $\mathrm{H}_{2} \mathrm{O}(\sim 50 \mathrm{~mL})$ and extracted with hexanes $(3 \mathrm{x})$. The combined organic layers were washed with brine, dried with $\mathrm{Na}_{2} \mathrm{SO}_{4}$ and concentrated in vacuo. The resulting liquid was purified via distillation to give the title compound as a colorless liquid $(2.31 \mathrm{~g}, 10.13$ mmol, 51\%) b.p. $=100{ }^{\circ} \mathrm{C}, \sim 300$ mtorr. ${ }^{1} \mathrm{H}$ NMR $\left(400 \mathrm{MHz}, \mathrm{CDCl}_{3}\right) \delta 7.52-7.60(\mathrm{~m}, 2 \mathrm{H}), 6.92(\mathrm{~m}, 2 \mathrm{H})$, $3.83(\mathrm{~s}, 3 \mathrm{H}), 3.61(\mathrm{~s}, 9 \mathrm{H}) .{ }^{13} \mathrm{C}$ NMR $\left(100 \mathrm{MHz}, \mathrm{CDCl}_{3}\right) \delta 161.8,136.5,120.4,113.9,55.1,50.9$; IR (neat) 3053, 2943, 2840, 2148, 1596, 1505, 1181, 1074, 1030, 802, $741 \mathrm{~cm}^{-1}$; HRMS (ESI): Mass calculated for $\mathrm{C}_{10} \mathrm{H}_{16} \mathrm{O}_{4} \mathrm{SiNa}[\mathrm{M}+\mathrm{Na}]^{+}, 251.0710$. Found $[\mathrm{M}+\mathrm{Na}]^{+}, 251.0705$

OMe

(4-methoxyphenyl)silane (SI-2): To a flame dried round bottom flask was added $\mathrm{LiAlH}_{4}(997$ $\mathrm{mg}, 26.28 \mathrm{mmol}, 2.0$ equiv.) and $\mathrm{Et}_{2} \mathrm{O}(48 \mathrm{~mL})$. The mixture was cooled to $0{ }^{\circ} \mathrm{C}$ and a solution of SI-1 (3.0 g, 13.14 mmol, 1 equiv.) in $\mathrm{Et}_{2} \mathrm{O}(12 \mathrm{~mL})$ was added slowly and allowed to stir for $3 \mathrm{~h}$ at $23{ }^{\circ} \mathrm{C}$. The reaction mixture was then diluted with $200 \mathrm{~mL}$ of pentanes and stirred for $20 \mathrm{~min}$ and then filtered through Celite and concentrated in vacuo. The resulting residue was diluted with an additional $200 \mathrm{~mL}$ of pentanes and filtered through Celite and concentrated in vacuo to yield the title compound as a colorless liquid (1.49 g, $10.78 \mathrm{mmol}, 82 \%)$. ${ }^{1} \mathrm{H} \mathrm{NMR}\left(400 \mathrm{MHz}, \mathrm{CDCl}_{3}\right) \delta$ 7.51-7.54 $(\mathrm{m}, 2 \mathrm{H}), 6.91-6.94(\mathrm{~m}, 2 \mathrm{H}), 4.20(\mathrm{~s}, 3 \mathrm{H}), 3.83(\mathrm{~s}, 3 \mathrm{H}) .{ }^{13} \mathrm{C}$ NMR $\left(100 \mathrm{MHz}, \mathrm{CDCl}_{3}\right) \delta 161.3,137.5,118.6$, 114.1, 55.1; IR (neat) 3004, 2955, 2836, 2147, 1593, 1501, 1278, 1247, 1181, 1116, 913, $747 \mathrm{~cm}^{-1}$

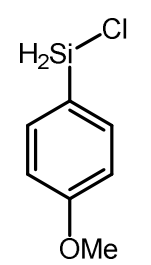

chloro(4-methoxyphenyl)silane (SI-3): To a flame dried round bottom flask was added SI-2 (500 mg, $3.61 \mathrm{mmol}, 1.0$ equiv.) and pentanes $(5.5 \mathrm{~mL})$ and cooled to $0{ }^{\circ} \mathrm{C} . \mathrm{BCl}_{3}(1 \mathrm{M}$ in $\mathrm{CH}_{2} \mathrm{Cl}_{2}, 1.44 \mathrm{~mL}, 1.44 \mathrm{mmol}, 0.4$ equiv) was added slowly and the reaction was stirred overnight at $23^{\circ} \mathrm{C}$. The reaction mixture was filtered through cotton and concentrated in vacuo. The resulting residue was diluted with pentanes and filtered again through cotton and concentrated in vacuo to yield the title compound as a colorless liquid (574 mg, $3.24 \mathrm{mmol}$, $92 \%)^{1} \mathrm{H}$ NMR $\left(400 \mathrm{MHz}, \mathrm{CDCl}_{3}\right) \delta$ 7.60-7.63 (m, 2H), 6.97-6.99 (m, 2H), 5.22 (s, 2H), $3.84(\mathrm{~s}$, $3 \mathrm{H}) .{ }^{13} \mathrm{C}$ NMR $\left(100 \mathrm{MHz}, \mathrm{CDCl}_{3}\right) \delta 162.4,136.4$. 121.2, 114.4, 55.3. All other spectral data matched reported. ${ }^{2}$ 
Supporting Information

Page S3

\section{Synthesis of chloro(4-fluorophenyl)silane (SI-6):}<smiles></smiles>

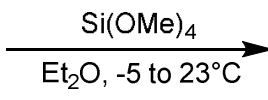<smiles>CO[Si]c1ccc(F)cc1</smiles><smiles>CCOCC</smiles><smiles>Fc1ccc(S)cc1</smiles><smiles>Fc1ccc([SiH2]Cl)cc1</smiles>

SI-6<smiles>CO[SiH](C)c1ccc(F)cc1</smiles>

(4-fluorophenyl)trimethoxysilane (SI-4) ${ }^{1}$ : To a flame dried 2-neck round bottom flask equipped with a water-cooled condenser was added magnesium turnings $(5.83 \mathrm{~g}, 240 \mathrm{mmol}$, 1.7 equiv.), which were freshly washed with $1 \mathrm{M} \mathrm{HCl}$ in methanol, three iodine crystals and $\mathrm{Et}_{2} \mathrm{O}(170 \mathrm{~mL})$. 1-bromo-4-fluorobenzene $(15.4 \mathrm{~mL}, 140 \mathrm{mmol}, 1.0$ equiv.) was added slowly over the course of 45 minutes to the refluxing mixture of $\mathrm{Et}_{2} \mathrm{O}$ and magnesium turnings. After complete addition of 1-bromo-4-fluorobenzene, the mixture was refluxed for an additional hour. The resulting Grignard reagent was cooled to $23{ }^{\circ} \mathrm{C}$ and added slowly to a solution containing $\mathrm{Si}(\mathrm{OMe})_{4}(62.5 \mathrm{~mL}, 420 \mathrm{mmol}, 3.0$ equiv. $)$ and $\mathrm{Et}_{2} \mathrm{O}(270 \mathrm{~mL})$ at $-5^{\circ} \mathrm{C}$. The resulting mixture was then warmed to $23{ }^{\circ} \mathrm{C}$ and stirred overnight. The reaction mixture was diluted with $\mathrm{H}_{2} \mathrm{O}(\sim 300 \mathrm{~mL})$ and extracted with hexanes (3x). The combined organic layers were washed with brine, dried with $\mathrm{Na}_{2} \mathrm{SO}_{4}$ and concentrated in vacuo. The resulting liquid was purified via distillation to give the title compound as a colorless liquid (19.37 g, $89.6 \mathrm{mmol}, 64 \%)$ b.p. $=95{ }^{\circ} \mathrm{C}, 8$ torr. ${ }^{1} \mathrm{H}$ NMR $\left(400 \mathrm{MHz}, \mathrm{CDCl}_{3}\right)$ ठ 7.62-7.66 (m, $2 \mathrm{H}), 7.07-7.11(\mathrm{~m}, 2 \mathrm{H}), 3.62(\mathrm{~s}, 9 \mathrm{H}) .{ }^{13} \mathrm{C}$ NMR $\left(100 \mathrm{MHz}, \mathrm{CDCl}_{3}\right) \delta 164.8\left(\mathrm{~d}, \mathrm{~J}_{\mathrm{CF}}=250.1 \mathrm{~Hz}\right), 137.1(\mathrm{~d}$, $J_{\mathrm{CF}}=7.9 \mathrm{~Hz}$ ), $125.3\left(\mathrm{~d}, J_{\mathrm{CF}}=3.7 \mathrm{~Hz}\right) 115.4\left(\mathrm{~d}, J_{\mathrm{CF}}=20.1 \mathrm{~Hz}\right.$ ), 50.9; IR (neat) 3053, 2945, 2843, 2147, 1591, 1501, 1264, 1076, 825, 736, $703 \mathrm{~cm}^{-1}$; HRMS (ESI): Mass calculated for $\mathrm{C}_{9} \mathrm{H}_{13} \mathrm{O}_{3} \mathrm{FSiNa}[\mathrm{M}+\mathrm{Na}]^{+}$, 239.0510. Found $[\mathrm{M}+\mathrm{Na}]^{+}, 239.0510$.

(1)

(4-fluorophenyl)silane (SI-5): To a flame dried round bottom flask was added $\mathrm{LiAlH}_{4}(1.05 \mathrm{~g}$, $27.74 \mathrm{mmol}, 2.0$ equiv.) and $\mathrm{Et}_{2} \mathrm{O}(48 \mathrm{~mL})$. The mixture was cooled to $0{ }^{\circ} \mathrm{C}$ and a solution of $\mathrm{SI}-4$ $\left(3.0 \mathrm{~g}, 13.87 \mathrm{mmol}, 1.0\right.$ equiv.) in $\mathrm{Et}_{2} \mathrm{O}(12 \mathrm{~mL})$ was added slowly and allowed to stir for $3 \mathrm{~h}$ at 23 ${ }^{\circ} \mathrm{C}$. The reaction mixture was then diluted with $200 \mathrm{~mL}$ of pentanes and stirred for $20 \mathrm{~min}$ and then filtered through Celite and concentrated in vacuo. The resulting residue was diluted with an additional $200 \mathrm{~mL}$ of pentanes and filtered through Celite and concentrated in vacuo to yield the title compound as a colorless liquid $(895 \mathrm{mg})$. The compound is very volatile, so was used in the next synthetic step with trace pentanes left over. See attached H-NMR. ${ }^{1} \mathrm{H}$ NMR $\left(400 \mathrm{MHz}, \mathrm{CDCl}_{3}\right) \delta$ 7.55-7.59 $(\mathrm{m}, 2 \mathrm{H}), 7.04-7.09(\mathrm{~m}, 2 \mathrm{H}), 4.20(\mathrm{~s}, 3 \mathrm{H})$.<smiles>Fc1ccc([SiH2]Cl)cc1</smiles>

chloro(4-fluorophenyl)silane (SI-6): To a flame dried round bottom flask was added crude SI$5(895 \mathrm{mg})$ and pentanes $(10 \mathrm{~mL})$ and cooled to $0{ }^{\circ} \mathrm{C} . \mathrm{BCl}_{3}\left(1 \mathrm{M}\right.$ in $\mathrm{CH}_{2} \mathrm{Cl}_{2}, 2.84 \mathrm{~mL}, 2.84 \mathrm{mmol}$, 0.4 equiv.) was added slowly and the reaction was stirred overnight at $23{ }^{\circ} \mathrm{C}$. The reaction mixture was filtered through cotton and concentrated in vacuo. The resulting residue was diluted with pentanes and filtered again through cotton and concentrated in vacuo to yield the title compound as a colorless liquid (666 mg, $4.15 \mathrm{mmol}, 58 \%$ over 2 steps). This compound is very reactive as indicated by purity of $\mathrm{H}-\mathrm{NMR}$, but can be used effectively as a reagent for the synthetic method described. ${ }^{1} \mathrm{H}$ NMR $\left(400 \mathrm{MHz}, \mathrm{CDCl}_{3}\right) \delta$ 7.66-7.70 $(\mathrm{m}, 2 \mathrm{H}), 7.13-7.17(\mathrm{~m}, 2 \mathrm{H}), 5.23(\mathrm{~s}$, $2 \mathrm{H}) .{ }^{13} \mathrm{C}$ NMR $\left(150 \mathrm{MHz}, \mathrm{CDCl}_{3}\right) \delta 165.2\left(\mathrm{~d}, \mathrm{~J}_{\mathrm{CF}}=252.0 \mathrm{~Hz}\right), 136.9\left(\mathrm{~d}, \mathrm{~J}_{\mathrm{CF}}=7.9 \mathrm{~Hz}\right), 126.0\left(\mathrm{~d}, \mathrm{~J}_{\mathrm{CF}}=3.4\right.$ $\mathrm{Hz}$ ) $116.0\left(\mathrm{~d}, J_{\mathrm{CF}}=20.7 \mathrm{~Hz}\right.$ ); IR (neat) 3053, 2945, 2843, 2147, 1591, 1501, 1264, 1076, 825, 736, 703 $\mathrm{cm}^{-1}$ 
Synthesis of chloro(naphthalen-1-yl)silane (SI-9):<smiles>CO[Si](C)c1cccc2ccccc12</smiles>

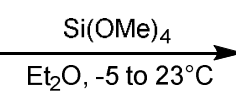<smiles>CO[Si]c1cccc2ccccc12</smiles>

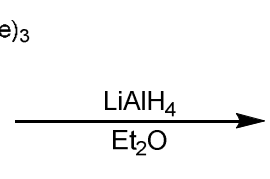

$$
\mathrm{Et}_{2} \mathrm{O}
$$<smiles>Sc1cccc2ccccc12</smiles>

$\mathrm{SI}-8$

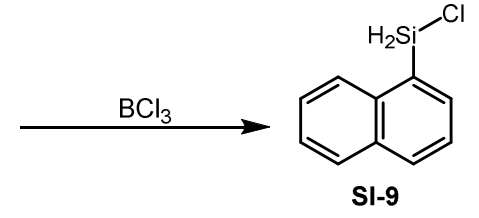

SI-9

trimethoxy(naphthalen-1-yl)silane (SI-7) ${ }^{1}$ : To a flame dried 2-neck round bottom flask equipped with a water-cooled condenser was added magnesium turnings (266 mg, 11.0 mmol, 1.1 equiv.), which were freshly washed with $1 \mathrm{M} \mathrm{HCl}$ in methanol, three iodine crystals and $\mathrm{Et}_{2} \mathrm{O}$ (13 mL). 1-bromonaphthalene (1.40 mL, $10 \mathrm{mmol}, 1.0$ equiv.) was added slowly over the course of 45 minutes to the refluxing mixture of $\mathrm{Et}_{2} \mathrm{O}$ and magnesium turnings. After complete addition of 1-bromonaphthalene, the mixture was refluxed for an additional hour. The resulting Grignard reagent was cooled to $23{ }^{\circ} \mathrm{C}$ and added slowly to a solution containing $\mathrm{Si}(\mathrm{OMe})_{4}(4.42 \mathrm{~mL}, 30 \mathrm{mmol}, 3.0$ equiv. $)$ and $\mathrm{Et}_{2} \mathrm{O}(13 \mathrm{~mL})$ at $-5{ }^{\circ} \mathrm{C}$. The resulting mixture was then warmed to $23{ }^{\circ} \mathrm{C}$ and stirred overnight. The reaction mixture was diluted with $\mathrm{H}_{2} \mathrm{O}(\sim 50 \mathrm{~mL})$ and extracted with hexanes (3x). The combined organic layers were washed with brine, dried with $\mathrm{Na}_{2} \mathrm{SO}_{4}$ and concentrated in vacuo. The resulting liquid was purified via distillation to give the title compound as a colorless liquid, which solidified upon standing. (1.87 g, $7.53 \mathrm{mmol}, 75 \%)$. ${ }^{1} \mathrm{H}$ NMR $\left(400 \mathrm{MHz}, \mathrm{C}_{6} \mathrm{D}_{6}\right) \delta$ $8.65(\mathrm{~d}, J=8.4 \mathrm{~Hz}, 1 \mathrm{H}), 8.15-8.17(\mathrm{~m}, 1 \mathrm{H}), 7.70(\mathrm{~d}, J=8.2 \mathrm{~Hz}, 1 \mathrm{H}), 7.63-7.65(\mathrm{~m}, 1 \mathrm{H}), 7.38-7.42(\mathrm{~m}, 1 \mathrm{H})$, 7.25-7.32 (m, 2H). ${ }^{13} \mathrm{C}$ NMR $\left(100 \mathrm{MHz}, \mathrm{C}_{6} \mathrm{D}_{6}\right) \delta 137.8,136.6,133.9,131.6,129.1,129.0,128.9,126.8$, 126.0, 125.3, 50.5. All other spectral data matched reported. ${ }^{3}$<smiles>Sc1cccc2ccccc12</smiles>

naphthalen-1-ylsilane (SI-8): To a flame dried round bottom flask was added $\mathrm{LiAlH}_{4}(611$ $\mathrm{mg}, 16.1 \mathrm{mmol}, 2.0$ equiv.) and $\mathrm{Et}_{2} \mathrm{O}(32 \mathrm{~mL})$. The mixture was cooled to $0{ }^{\circ} \mathrm{C}$ and a solution of SI-7 (2.0 g, $8.05 \mathrm{mmol}, 1$ equiv.) in $\mathrm{Et}_{2} \mathrm{O}(8 \mathrm{~mL})$ was added slowly and allowed to stir for $3 \mathrm{~h}$ at $23{ }^{\circ} \mathrm{C}$. The reaction mixture was then diluted with $200 \mathrm{~mL}$ of pentanes and stirred for $20 \mathrm{~min}$ and then filtered through Celite and concentrated in vacuo. The resulting residue was diluted with an additional $200 \mathrm{~mL}$ of pentanes and filtered through Celite and concentrated in vacuo to yield the title compound as a colorless liquid $(1.20 \mathrm{~g}, 7.58 \mathrm{mmol}, 94 \%) .{ }^{1} \mathrm{H} \mathrm{NMR}(400 \mathrm{MHz}$, $\left.\mathrm{CDCl}_{3}\right) \delta$ 7.84-7.99 (m, 4H), 7.51-7.59 (m, 2H), 7.45-7.49 (m, $\left.1 \mathrm{H}\right), 4.49(\mathrm{~s}, 3 \mathrm{H}) .{ }^{13} \mathrm{C}$ NMR $(100 \mathrm{MHz}$, $\left.\mathrm{CDCl}_{3}\right) \delta 137.6,136.9,133.1,131.1,128.9,127.9,127.4,126.6,126.1,125.4$. All other spectral data matched reported. ${ }^{4}$<smiles>Cl[SiH2]c1cccc2ccccc12</smiles>

chloro(naphthalen-1-yl)silane (SI-9): To a flame dried round bottom flask was added SI-8 $\left(1.5 \mathrm{~g}, 9.6 \mathrm{mmol}, 1.0\right.$ equiv.) and hexanes $(5.6 \mathrm{~mL})$ and cooled to $0{ }^{\circ} \mathrm{C} . \mathrm{BCl}_{3}\left(1 \mathrm{M} \mathrm{in} \mathrm{CH}_{2} \mathrm{Cl}_{2}\right.$, $3.84 \mathrm{~mL}, 3.84 \mathrm{mmol}, 0.4$ equiv.) was added slowly and the reaction was stirred overnight at $23{ }^{\circ} \mathrm{C}$. The reaction mixture was filtered through cotton and concentrated in vacuo. The resulting residue was diluted with pentanes and filtered again through cotton and concentrated in vacuo to yield the title compound as a yellow liquid ( $1.76 \mathrm{~g}, 9.1 \mathrm{mmol}, 95 \%){ }^{1} \mathrm{H}$ NMR $\left(400 \mathrm{MHz}, \mathrm{CDCl}_{3}\right) \delta 8.11(\mathrm{~d}, J=8.2 \mathrm{~Hz}, 1 \mathrm{H}), 8.01(\mathrm{~d}, J=8.3 \mathrm{~Hz}, 1 \mathrm{H}), 7.89-7.94(\mathrm{~m}, 2 \mathrm{H}), 7.51-7.63(\mathrm{~m}$, 3H) $5.57(\mathrm{~s}, 2 \mathrm{H}) .{ }^{13} \mathrm{C} \mathrm{NMR}\left(100 \mathrm{MHz}, \mathrm{CDCl}_{3}\right) \delta 136.3,136.2,133.3,132.6,129.2,128.6,127.2,127.1$, 126.5, 125.3; IR (neat) 3051, 2147, 1504, 1063, 809, 775, $667 \mathrm{~cm}^{-1}$; 
Synthesis of chloro(mesityl)silane (SI-12):

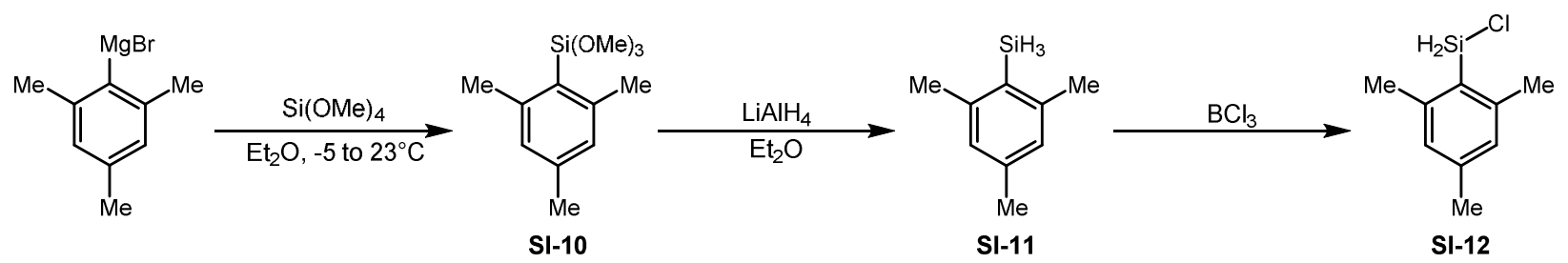<smiles>CO[SiH2]c1c(C)cc(C)cc1C</smiles>

mesityltrimethoxysilane (SI-10) ${ }^{1}$ : To a flame dried 2-neck round bottom flask equipped with a water-cooled condenser was added magnesium turnings $(2.33 \mathrm{~g}, 96 \mathrm{mmol}, 1.2$ equiv.), which were freshly washed with $1 \mathrm{M} \mathrm{HCl}$ in methanol, three iodine crystals and $\mathrm{Et}_{2} \mathrm{O}(70 \mathrm{~mL})$. 2-bromomesitylene $(12.24 \mathrm{~mL}, 80 \mathrm{mmol}, 1.0$ equiv.) was added slowly over the course of 45 minutes to the refluxing mixture of $\mathrm{Et}_{2} \mathrm{O}$ and magnesium turnings. After complete addition of 2-bromomesitylene, the mixture was refluxed for an additional hour. The resulting Grignard reagent was cooled to $23{ }^{\circ} \mathrm{C}$ and added slowly to a solution containing $\mathrm{Si}(\mathrm{OMe})_{4}\left(35.7 \mathrm{~mL}, 240 \mathrm{mmol}, 3.0\right.$ equiv.) and $\mathrm{Et}_{2} \mathrm{O}(160 \mathrm{~mL})$ at $-5{ }^{\circ} \mathrm{C}$. The resulting mixture was then warmed to $23{ }^{\circ} \mathrm{C}$ and stirred overnight. The reaction mixture was diluted with $\mathrm{H}_{2} \mathrm{O}(\sim 400 \mathrm{~mL})$ and extracted with hexanes $(3 \mathrm{x})$. The combined organic layers were washed with brine, dried with $\mathrm{Na}_{2} \mathrm{SO}_{4}$ and concentrated in vacuo. The resulting liquid was purified via distillation to give the title compound as a colorless liquid $(3.07 \mathrm{~g}, 12.8 \mathrm{mmol}, 16 \%)$ b.p. $=90{ }^{\circ} \mathrm{C}, \sim 300$ mtorr. ${ }^{1} \mathrm{H} \mathrm{NMR}\left(400 \mathrm{MHz}, \mathrm{CDCl}_{3}\right) \delta 6.84(\mathrm{~s}$, $2 \mathrm{H}$ ), 3.59 (s, 9h), $2.48(\mathrm{~s}, 6 \mathrm{H}), 2.26(\mathrm{~s}, 3 \mathrm{H}) .{ }^{13} \mathrm{C}$ NMR $\left(100 \mathrm{MHz}, \mathrm{CDCl}_{3}\right) \delta 146.1,140.2,129.0,124.1$, 50.2, 23.6, 21.2; IR (neat) 3052, 2942, 2840, 2153, 1605, 1501, 1265, 1077, 914, $740 \mathrm{~cm}^{-1}$; HRMS (ESI): Mass calculated for $\mathrm{C}_{12} \mathrm{H}_{20} \mathrm{O}_{3} \mathrm{SiNa}[\mathrm{M}+\mathrm{Na}]^{+}, 263.1074$. Found $[\mathrm{M}+\mathrm{Na}]^{+}, 263.1080$.<smiles>Cc1cc([N+](=O)[O-])cc(C)c1[Na]</smiles>

mesitylsilane (SI-11): To a flame dried round bottom flask was added $\mathrm{LiAlH}_{4}(631 \mathrm{mg}$, $16.64 \mathrm{mmol}, 2.0$ equiv.) and $\mathrm{Et}_{2} \mathrm{O}(32 \mathrm{~mL})$. The mixture was cooled to $0{ }^{\circ} \mathrm{C}$ and $\mathrm{a}$ solution of SI-10 (2.0 g, $8.32 \mathrm{mmol}, 1.0$ equiv.) in $\mathrm{Et}_{2} \mathrm{O}(8 \mathrm{~mL})$ was added slowly and allowed to stir for $3 \mathrm{~h}$ at $23{ }^{\circ} \mathrm{C}$. The reaction mixture was then diluted with $200 \mathrm{~mL}$ of pentanes and stirred for $20 \mathrm{~min}$ and then filtered through Celite and concentrated in vacuo. The resulting residue was diluted with an additional $200 \mathrm{~mL}$ of pentanes and filtered through Celite and concentrated in vacuo to yield the title compound as a colorless liquid $(1.10 \mathrm{~g}$, $7.3 \mathrm{mmol}, 88 \%)$. ${ }^{1} \mathrm{H}$ NMR $\left(400 \mathrm{MHz}, \mathrm{CDCl}_{3}\right) \delta 6.86(\mathrm{~s}, 2 \mathrm{H}), 4.14(\mathrm{~s}, 3 \mathrm{H}), 2.42(\mathrm{~s}, 6 \mathrm{H}), 2.27(\mathrm{~s}, 3 \mathrm{H}) .{ }^{13} \mathrm{C}$ NMR $\left(100 \mathrm{MHz}, \mathrm{CDCl}_{3}\right) \delta 141.1,140.0,128.2,123.4,23.7,21.3$. All other spectral data matched reported. ${ }^{5}$<smiles>Cc1cc(C)c([SiH2]Cl)c(C)c1</smiles>

chloro(mesityl)silane (SI-12): To a flame dried round bottom flask was added SI-11 (622 $\mathrm{mg}, 4.14 \mathrm{mmol}, 1.0$ equiv.) and hexanes $(6 \mathrm{~mL})$ and cooled to $0{ }^{\circ} \mathrm{C} . \mathrm{BCl}_{3}(1 \mathrm{M}$ in $\mathrm{CH}_{2} \mathrm{Cl}_{2}, 1.66 \mathrm{~mL}, 1.66 \mathrm{mmol}, 0.4$ equiv.) was added slowly and the reaction was stirred overnight at $23^{\circ} \mathrm{C}$. The reaction mixture was filtered through cotton and concentrated in vacuo. The resulting residue was diluted with pentanes and filtered again through cotton and concentrated in vacuo to yield the title compound as a colorless liquid (610 mg, 3.30 $\mathrm{mmol}, 80 \%)^{1} \mathrm{H}$ NMR (400 MHz, $\left.\mathrm{CDCl}_{3}\right) \delta 6.89(\mathrm{~s}, 2 \mathrm{H}), 5.36(\mathrm{~s}, 2 \mathrm{H}), 2.53(\mathrm{~s}, 6 \mathrm{H}), 2.29$ (s, 3H). ${ }^{13} \mathrm{C}$ NMR $\left(100 \mathrm{MHz}, \mathrm{CDCl}_{3}\right) \delta 144.9,137.9,128.8,127.0,23.0,21.3$. All other spectral data matched reported. ${ }^{6}$ 


\section{Synthesis of SI-14:}<smiles>Oc1ccc2ccccc2c1-c1c(O)ccc2ccccc12</smiles>

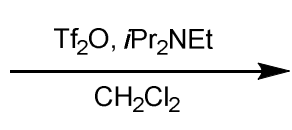<smiles>Oc1ccc2ccccc2c1-c1c(O)ccc2ccccc12</smiles>

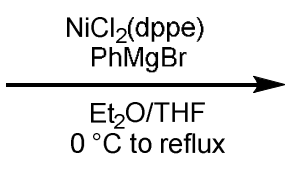

SI-13<smiles>Oc1ccc2ccccc2c1-c1c(-c2ccccc2)ccc2ccccc12</smiles>

SI-14<smiles>Oc1ccc2ccccc2c1-c1c(O)ccc2ccccc12</smiles>

2'-hydroxy-[1,1'-binaphthalen]-2-yl trifluoromethanesulfonate (SI-13) ${ }^{7}$ :To a flamedried round bottom flask was added $(R)$-BINOL $(42.95 \mathrm{~g}, 150 \mathrm{mmol}, 1.0$ equiv.) followed by $\mathrm{CH}_{2} \mathrm{Cl}_{2}(1500 \mathrm{~mL})$. The solution was cooled to $0{ }^{\circ} \mathrm{C}$ and $\operatorname{Pr}_{2} \mathrm{NEt}(31.4 \mathrm{~mL}$, $180 \mathrm{mmol}, 1.2$ equiv.) was added followed by the slow addition of $\mathrm{Tf}_{2} \mathrm{O}(30.2 \mathrm{~mL}, 180$ mmol, 1.2 equiv). The reaction was warmed to $23{ }^{\circ} \mathrm{C}$ and stirred overnight. The reaction was cooled to $0{ }^{\circ} \mathrm{C}$, quenched with $2 \mathrm{M} \mathrm{HCl}$ and extracted with $\mathrm{CH}_{2} \mathrm{Cl}_{2}(3 \mathrm{x})$. The combined organic layers were washed with $\mathrm{NaHCO}_{3}$, brine, dried with $\mathrm{Na}_{2} \mathrm{SO}_{4}$, and concentrated in vacuo. The resulting crude SI-13 was run through a large silica gel plug and used as is for the next step of the synthetic sequence.<smiles>Oc1ccc2ccccc2c1-c1c(-c2ccccc2)ccc2ccccc12</smiles>

2'-phenyl-[1,1'-binaphthalen]-2-ol (SI-14) ${ }^{7}$ : To a flame-dried round bottom flask was added slightly impure Sl-13 (49.51 g, $118 \mathrm{mmol}, 1.0$ equiv.), THF (250 mL), and $\mathrm{Ni}(\mathrm{dppe}) \mathrm{Cl}_{2}\left(2.40 \mathrm{~g}, 4.55 \mathrm{mmol}, 0.04\right.$ equiv). The mixture was cooled to $0{ }^{\circ} \mathrm{C}$ and freshly prepared $\mathrm{PhMgBr}$ solution ( $390 \mathrm{mmol}, 5.0$ equiv.) was added drop wise at $0{ }^{\circ} \mathrm{C}$. The flask was equipped with a water-cooled condenser and the reaction was heated to reflux overnight. The reaction was cooled to $0{ }^{\circ} \mathrm{C}$ and quenched with saturated $\mathrm{NH}_{4} \mathrm{Cl}$ (aq) The mixture was filtered through Celite and extracted with $\mathrm{Et}_{2} \mathrm{O}(3 \mathrm{x})$. The combined organic layers were washed with saturated $\mathrm{NaHCO}_{3}(\mathrm{aq})$, brine, dried with $\mathrm{Na}_{2} \mathrm{SO}_{4}$, and concentrated in vacuo. The resulting compound was purified via flash column chromatography on silica gel (5:95 EtOAc:hexanes) to afford the title compound as a yellow oil $(38.57 \mathrm{~g}, 111.3 \mathrm{mmol}, 74 \%$ over $2 \mathrm{steps}) .{ }^{1} \mathrm{H}$ $\operatorname{NMR}\left(400 \mathrm{MHz}, \mathrm{CDCl}_{3}\right) \delta 8.09(\mathrm{~d}, J=8.4,1 \mathrm{H}), 7.99(\mathrm{~d}, J=8.2 \mathrm{~Hz}, 1 \mathrm{H}), 7.77(\mathrm{~d}, J=8.7,2 \mathrm{H}), 7.72(\mathrm{~d}, J=$ $8.5 \mathrm{~Hz}, 1 \mathrm{H}), 7.50-7.54(\mathrm{~m}, 1 \mathrm{H}), 7.19-7.35(\mathrm{~m}, 5 \mathrm{H}), 7.03-7.15(\mathrm{~m}, 6 \mathrm{H}), 4.82(\mathrm{~s}, 1 \mathrm{H})$. All other spectral data matched reported. ${ }^{6}$

\section{Synthesis of SI-16:}<smiles>Oc1ccc2ccccc2c1-c1c(-c2ccccc2)ccc2ccccc12</smiles>

SI-14<smiles>CCCc1ccc2ccccc2c1-c1c(-c2ccccc2)ccc2ccccc12</smiles>

$\mathrm{SI}-15$

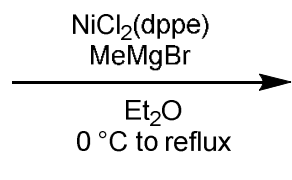

SI-16<smiles>CCCc1ccc2ccccc2c1-c1c(-c2ccccc2)ccc2ccccc12</smiles>

2'-phenyl-[1,1'-binaphthalen]-2-yl trifluoromethanesulfonate(SI-15) ${ }^{7}$ : To a flamedried round bottom flask was added SI-14 $(38.57 \mathrm{~g}, 111 \mathrm{mmol}, 1.0$ equiv.) followed by $\mathrm{CH}_{2} \mathrm{Cl}_{2}(500 \mathrm{~mL})$. The solution was cooled to $0{ }^{\circ} \mathrm{C}$ and pyridine $(12.54 \mathrm{~mL}, 155 \mathrm{mmol}$, 1.4 equiv.) was added followed by the slow addition of $\mathrm{Tf}_{2} \mathrm{O}(22.34 \mathrm{~mL}, 133 \mathrm{mmol}, 1.2$ equiv.). The reaction was warmed to r.t. and stirred overnight. The reaction was cooled 
to $0{ }^{\circ} \mathrm{C}$, quenched with $2 \mathrm{M} \mathrm{HCl}$ and extracted with $\mathrm{CH}_{2} \mathrm{Cl}_{2}(3 \mathrm{x})$. The combined organic layers were washed with $\mathrm{NaHCO}_{3}$, brine, dried with $\mathrm{Na}_{2} \mathrm{SO}_{4}$, and concentrated in vacuo. The resulting residue was purified via flash column chromatography on silica gel (2:98 EtOAc:hexanes) to afford the title compound as a white solid (38.6 g, $80.67 \mathrm{mmol}, 73 \%)$. ${ }^{1} \mathrm{H}$ NMR $\left(400 \mathrm{MHz}, \mathrm{CDCl}_{3}\right) \delta 8.08(\mathrm{~d}, J=8.3 \mathrm{~Hz}, 1 \mathrm{H}), 7,89$ $7.98(\mathrm{~m}, 3 \mathrm{H}), 7.66(\mathrm{~d}, J=8.5,1 \mathrm{H}), 7.40-7.57(\mathrm{~m}, 4 \mathrm{H}), 7.27-7.32(\mathrm{~m}, 2 \mathrm{H}), 7.16-7.18(\mathrm{~m}, 1 \mathrm{H}), 6.99-7.11(\mathrm{~m}$, $5 \mathrm{H})$. All other spectral data matched reported. ${ }^{6}$<smiles>Cc1ccc2ccccc2c1-c1c(-c2ccccc2)ccc2ccccc12</smiles>

2-methyl-2'-phenyl-1,1'-binaphthalene (SI-16) ${ }^{7}$ : To a flame-dried round bottom flask was added SI-15 (36.35 g, $76 \mathrm{mmol}, 1.0$ equiv.), THF (80 mL), and $\mathrm{Ni}(\mathrm{dppe}) \mathrm{Cl}_{2}(1.20$ $\mathrm{g}, 2.30 \mathrm{mmol}, 0.03$ equiv.). The mixture was cooled to $0{ }^{\circ} \mathrm{C}$ and $\mathrm{MeMgBr}$ solution (2.6 $\mathrm{M}$ in $\mathrm{Et}_{2} \mathrm{O}, 87.7 \mathrm{~mL}, 228 \mathrm{mmol}, 3.0$ equiv.) was added drop wise at $0{ }^{\circ} \mathrm{C}$. The flask was then equipped with a water-cooled condenser and the reaction was heated to reflux and stirred overnight. The reaction was cooled to $0{ }^{\circ} \mathrm{C}$ and quenched with saturated $\mathrm{NH}_{4} \mathrm{Cl}$ (aq). The mixture was filtered through Celite and extracted with $\mathrm{Et}_{2} \mathrm{O}(3 \mathrm{x})$. The combined organic layers were washed with saturated $\mathrm{NaHCO}_{3}$ (aq), brine, dried with $\mathrm{Na}_{2} \mathrm{SO}_{4}$, and concentrated in vacuo. The resulting compound was purified via flash column chromatography on silica gel (hexanes) to afford the title compound an off-white solid $(25.37 \mathrm{~g}, 73.7 \mathrm{mmol}, 97 \%)$. ${ }^{1} \mathrm{H}$ NMR (400 $\left.\mathrm{MHz}, \mathrm{CDCl}_{3}\right) \delta 8.03(\mathrm{~d}, J=8.4 \mathrm{~Hz}, 1 \mathrm{H}), 7.96(\mathrm{~d}, J=8.1 \mathrm{~Hz}, 1 \mathrm{H}), 7.82(\mathrm{~d}, J=8.2 \mathrm{~Hz}, 1 \mathrm{H}), 7.74(\mathrm{~d}, J=8.4$ $\mathrm{Hz}, 1 \mathrm{H}), 7.66(\mathrm{~d}, J=8.5 \mathrm{~Hz}, 1 \mathrm{H}), 7.44-7.48(\mathrm{~m}, 1 \mathrm{H}), 7.34-7.38(\mathrm{~m}, 1 \mathrm{H}), 7.22-7.28(\mathrm{~m}, 4 \mathrm{H}), 7.11-7.13(\mathrm{~m}$, $1 \mathrm{H}), 6.98-7.06(\mathrm{~m}, 5 \mathrm{H}), 1.92(\mathrm{~s}, 3 \mathrm{H})$. All other spectral data matched reported. ${ }^{6}$

\section{Synthesis of 2:}<smiles>Cc1ccc2ccccc2c1-c1c(-c2ccccc2)ccc2ccccc12</smiles>
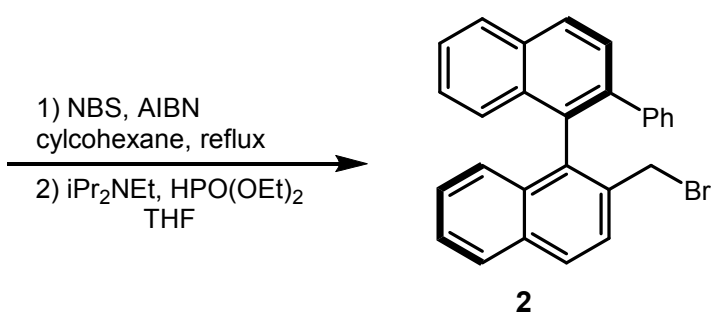<smiles>BrCc1ccc2ccccc2c1-c1c(-c2ccccc2)ccc2ccccc12</smiles>

2-(bromomethyl)-2'-phenyl-1,1'-binaphthalene $(2)^{7,8}$ : To a flame-dried round bottom flask was added SI-16 (6.28 g, $18.2 \mathrm{mmol}, 1.0$ equiv.), NBS (16.2 g, $91 \mathrm{mmol}$, 5.0 equiv.), AIBN (299 mg, $1.82 \mathrm{mmol}, 0.1$ equiv.) and cyclohexane (400 mL). The flask was then equipped with a water-cooled condenser and the reaction mixture was refluxed overnight. The reaction was then cooled to $23^{\circ} \mathrm{C}$ and filtered through Celite with $\mathrm{Et}_{2} \mathrm{O}$. The resulting solution was then diluted with $\mathrm{H}_{2} \mathrm{O}$ and extracted with $\mathrm{Et}_{2} \mathrm{O}$ (3x). The organic layers were combined and washed with saturated $\mathrm{NaHCO}_{3}(\mathrm{aq})$, brine, dried with $\mathrm{Na}_{2} \mathrm{SO}_{4}$, and concentrated in vacuo. The crude material (12.33 g) containing a mixture of mono-brominated and di-brominated products was added to a round bottom flask and dissolved in THF $(40 \mathrm{~mL})$. The resulting solution was cooled to $0{ }^{\circ} \mathrm{C}$ followed by the addition of $\operatorname{Pr}_{2} \mathrm{NEt}(31.70 \mathrm{~mL}, 182$ mmol, 10.0 equiv.) and diethyl phosphite $(23.44 \mathrm{~mL}, 182 \mathrm{mmol}, 10$ equiv.). The reaction mixture was then warmed to $23{ }^{\circ} \mathrm{C}$ and stirred overnight. The reaction was then cooled to $0{ }^{\circ} \mathrm{C}$ and quenched with $\mathrm{H}_{2} \mathrm{O}$, extracted with $\mathrm{Et}_{2} \mathrm{O}(3 \mathrm{x})$, washed with brine, dried with $\mathrm{Na}_{2} \mathrm{SO}_{4}$, and concentrated in vacuo. The resulting reside was filtered through a silica plug using $\mathrm{Et}_{2} \mathrm{O}$ as the eluent and concentrated. The crude material was then purified via recrystallization from cyclohexane to afford the title compound as an off-white solid (6.29 g, $14.86 \mathrm{mmol}, 82 \%$ over 2 steps). ${ }^{1} \mathrm{H}$ NMR $\left(400 \mathrm{MHz}, \mathrm{CDCl}_{3}\right) \delta 8.07$ (d, J = 8.4 Hz, $\left.1 \mathrm{H}\right), 7.97(\mathrm{~d}, J$ $=8.2 \mathrm{~Hz}, 1 \mathrm{H}), 7.84(\mathrm{~d}, J=8.5 \mathrm{~Hz}, 2 \mathrm{H}), 7.68(\mathrm{~d}, J=8.5,1 \mathrm{H}), 7.53(\mathrm{~d}, J=8.6 \mathrm{~Hz}, 1 \mathrm{H}), 7.42-7.51(\mathrm{~m}, 2 \mathrm{H})$, 7.24-7.30 (m, 5H), 7.11-13 (m, 1H), 6.98-7.08 $(\mathrm{m}, 5 \mathrm{H}), 4.18(\mathrm{~d}, J=10.3 \mathrm{~Hz}, 1 \mathrm{H}), 4.10(\mathrm{~d}, J=10.3 \mathrm{~Hz}$, $1 \mathrm{H})$. All other spectral data matched reported. ${ }^{6}$ 


\section{Synthesis of SI-17:}<smiles>BrCc1ccc2ccccc2c1-c1c(-c2ccccc2)ccc2ccccc12</smiles>

2

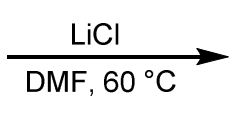

2-(chloromethyl)-2'-phenyl-1,1'-binaphthalene (SI-17): To a flame dried vial was added 2 (211 mg, $0.5 \mathrm{mmol}, 1.0$ equiv.), $\mathrm{LiCl}(85 \mathrm{mg}, 2.0 \mathrm{mmol}, 4.0$ equiv.) and DMF $(3 \mathrm{~mL})$. The reaction mixture was heated to $60{ }^{\circ} \mathrm{C}$ and stirred overnight. The reaction was then cooled to $23{ }^{\circ} \mathrm{C}$, diluted with $\mathrm{H}_{2} \mathrm{O}$, and extracted with $\mathrm{Et}_{2} \mathrm{O}(3 \mathrm{x})$. The combined organic layers were washed with $\mathrm{H}_{2} \mathrm{O}(3 \mathrm{x})$, brine, dried over $\mathrm{Na}_{2} \mathrm{SO}_{4}$, and concentrated in vacuo. The resulting solid was ran through a short silica plug using $\mathrm{CH}_{2} \mathrm{Cl}_{2}$ as the eluent and concentrated to afford the title compound as a white solid (175 mg, $0.462 \mathrm{mmol}, 92 \%)$. ${ }^{1} \mathrm{H}$ NMR $\left(400 \mathrm{MHz}, \mathrm{CDCl}_{3}\right) \delta 8.06(\mathrm{~d}, J=8.5 \mathrm{~Hz}, 1 \mathrm{H}), 7.97(\mathrm{~d}, \mathrm{~J}=8.2 \mathrm{~Hz}$, $1 \mathrm{H}), 7.85-7.88(\mathrm{~m}, 2 \mathrm{H}), 7.67(\mathrm{~d}, J=8.5 \mathrm{~Hz}, 1 \mathrm{H}), 7.58(\mathrm{~d}, J=8.6 \mathrm{~Hz}, 1 \mathrm{H}), 7.25-7.30(\mathrm{~m}, 3 \mathrm{H}), 7.12(\mathrm{~d}, J=$ $8.5 \mathrm{~Hz}, 1 \mathrm{H}), 6.98-7.13(\mathrm{~m}, 5 \mathrm{H}), 4.27(\mathrm{~d}, J=11.7 \mathrm{~Hz}, 1 \mathrm{H}), 4.17(\mathrm{~d}, J=11.7 \mathrm{~Hz}, 1 \mathrm{H}) .{ }^{13} \mathrm{C}$ NMR $(100 \mathrm{MHz}$, $\left.\mathrm{CDCl}_{3}\right) \delta 141.4$, 139.9, 135.6, 133.7, 133.5, 133.2, 132.9, 132.7, 128.9, 128.8, 128.7, 128.4, 128.2, 128.1, 127.7, 127.3, 127.1, 126.83, 126.81, 126.7, 126.3, 126.2, 44.7; mp 55-58 ㅇ; IR (neat) 3053, 2924, 2143, 1593, 1494, 1028, 912, 820, 747, $699 \mathrm{~cm}^{-1}$; HRMS (ESI): Mass calculated for $\mathrm{C}_{27} \mathrm{H}_{19} \mathrm{CINa}[\mathrm{M}+\mathrm{Na}]^{+}$, 401.1067. Found $[\mathrm{M}+\mathrm{Na}]^{+}, 401.1070 ;[\alpha]^{23} \mathrm{D}=124.2\left(\mathrm{c} 0.5, \mathrm{CHCl}_{3}\right)$.

\section{Synthesis of SI-18:}<smiles>BrCc1ccc2ccccc2c1-c1c(-c2ccccc2)ccc2ccccc12</smiles>

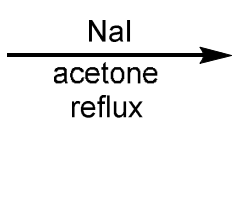<smiles>ICc1ccc2ccccc2c1-c1c(-c2ccccc2)ccc2ccccc12</smiles>

2-(iodomethyl)-2'-phenyl-1,1'-binaphthalene (SI-18): To a flame-dried round bottom flask was added 2 (211 mg, $0.5 \mathrm{mmol}, 1.0$ equiv.), Nal (225 mg, $1.5 \mathrm{mmol}, 3.0$ equiv.) and acetone $(3 \mathrm{~mL})$. The flask was then equipped with a water-cooled condenser and refluxed overnight. The reaction mixture was cooled to $23{ }^{\circ} \mathrm{C}$, diluted with $\mathrm{H}_{2} \mathrm{O}$ and extracted with Et2O (3x). The combined organic layers were washed with brine, dried over $\mathrm{Na}_{2} \mathrm{SO}_{4}$, and concentrated in vacuo. The resulting solid was

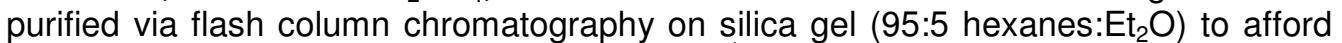
the title compound an off-white solid $(160 \mathrm{mg}, 0.340 \mathrm{mmol}, 68 \%) .{ }^{1} \mathrm{H}$ NMR $\left(400 \mathrm{MHz}, \mathrm{CDCl}_{3}\right) \delta 8.07(\mathrm{~d}, J$ $=8.5 \mathrm{~Hz}, 1 \mathrm{H}), 7.98(\mathrm{~d}, J=8.2 \mathrm{~Hz}, 1 \mathrm{H}), 7.79-7.84(\mathrm{~m}, 2 \mathrm{H}), 7.68(\mathrm{~d}, J=8.5 \mathrm{~Hz}, 1 \mathrm{H}), 7.42-7.51(\mathrm{~m}, 3 \mathrm{H})$, 7.25-7.30 (m, 3H), $7.12(\mathrm{~d}, J=8.5 \mathrm{~Hz}, 1 \mathrm{H}), 7.00-7.07(\mathrm{~m}, 5 \mathrm{H}), 4.11(\mathrm{~d}, J=9.5 \mathrm{~Hz}, 1 \mathrm{H}), 4.08(\mathrm{~d}, J=9.5$ $\mathrm{Hz}, 1 \mathrm{H}) .{ }^{13} \mathrm{C}$ NMR $\left(100 \mathrm{MHz}, \mathrm{CDCl}_{3}\right) \delta 141.4,139.6,135.1,134.7,134.1,133.1,132.9,132.6,132.5$, 129.0, 128.9, 128.8, 128.4, 128.3, 128.1, 127.8, 127.4, 127.2, 127.0, 126.9, 126.7, 126.3, 126.2, 5.5; mp 
61-65 우 IR (neat) 3053, 2922, 2147, 1589, 1264, 913, 735, $703 \mathrm{~cm}^{-1}$; HRMS (ESI): Mass calculated for $\mathrm{C}_{27} \mathrm{H}_{19} \mathrm{INa}[\mathrm{M}+\mathrm{Na}]^{+}, 493.0424$. Found $[\mathrm{M}+\mathrm{Na}]^{+}, 493.0412 ;[\alpha]^{23}=-31.5\left(\mathrm{c} 0.52, \mathrm{CHCl}_{3}\right)$.

\section{Synthesis of 1a via silyl lithium addition (Scheme 2c):}<smiles>BrCc1ccc2ccccc2c1-c1c(-c2ccccc2)ccc2ccccc12</smiles>

2

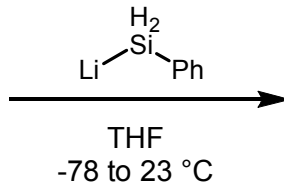

phenyl((2'-phenyl-[1,1'-binaphthalen]-2-yl)methyl)silane (1a):To a flame dried $8 \mathrm{~mL}$ vial was added Li metal (42 mg, $6.0 \mathrm{mmol}, 10$ equiv.) and THF $(0.75 \mathrm{~mL})$. The vial was cooled to $0{ }^{\circ} \mathrm{C}$ followed by the addition of phenylchlorosilane $(0.08$ $\mathrm{mL}, 0.6 \mathrm{mmol}, 1.0$ equiv,) and stirred vigorously at $23{ }^{\circ} \mathrm{C}$ for $3 \mathrm{~h}$ to generate (phenylsilyl)lithium. To a separate $8 \mathrm{~mL}$ vial was added $2(84.6 \mathrm{mg}, 0.2 \mathrm{mmol}, 1.0$ equiv.) and THF $(0.4 \mathrm{~mL})$. The reaction vial containing 2 was cooled to $-78{ }^{\circ} \mathrm{C}$ and the freshly prepared (phenylsilyl)lithium was added slowly. The reaction mixture was allowed to sir at $23{ }^{\circ} \mathrm{C}$ overnight. The reaction was then quenched with saturated $\mathrm{NH}_{4} \mathrm{Cl}_{(\mathrm{aq})}$ and extracted with $\mathrm{Et}_{2} \mathrm{O}(3 \mathrm{x})$. The combined organic layers were washed with brine, dried with $\mathrm{Na}_{2} \mathrm{SO}_{4}$, and concentrated in vacuo. The reaction yield was determined via ${ }^{1} \mathrm{H}-\mathrm{NMR}$ analysis of the crude material using 1,3,5-trimethoxy benzene as an internal standard, which was calculated to be $52 \%$. ${ }^{1} \mathrm{H}$ NMR $(400$ $\left.\mathrm{MHz}, \mathrm{CDCl}_{3}\right) \delta 8.03(\mathrm{~d}, J=8.4 \mathrm{~Hz}, 1 \mathrm{H}), 7.95(\mathrm{~d}, J=8.1 \mathrm{~Hz}, 1 \mathrm{H}), 7.82(\mathrm{~d}, J=8.2 \mathrm{~Hz}, 1 \mathrm{H}), 7.71(\mathrm{~d}, J=8.5$ $\mathrm{Hz}, 1 \mathrm{H}), 7.68(\mathrm{~d}, J=8.5 \mathrm{~Hz}, 1 \mathrm{H}), 7.43-7.47(\mathrm{~m}, 1 \mathrm{H}), 7.35-7.39(\mathrm{~m}, 1 \mathrm{H}), 7.28-7.32(\mathrm{~m}, 1 \mathrm{H})$, 7.16-7.25 $(\mathrm{m}$, $8 \mathrm{H}$ ), 6.98-7.13 (m, 6H), 3.96 (ddd, $J=6.8,4.7,3.4 \mathrm{~Hz}, 1 \mathrm{H}), 3.89-3.92(\mathrm{~m}, 1 \mathrm{H}), 2.12$ (ddd, $J=14.3,4.7$, $3.0 \mathrm{~Hz}, 1 \mathrm{H}), 2.04$ (ddd, $J=14.3,4.8,3.4 \mathrm{~Hz}, 1 \mathrm{H}) .{ }^{13} \mathrm{C} \mathrm{NMR}\left(100 \mathrm{MHz}, \mathrm{CDCl}_{3}\right) \delta 141.8,139.4,136.1$, 135.2, 134.8, 134.4, 133.7, 133.4, 133.0, 132.2, 131.3, 129.7, 129.1, 128.6, 128.4, 128.1, 128.0, 127.9, $127.8,127.6,127.5,126.7,126.6,126.4,126.3,126.0,124.7,18.2 ; \mathrm{mp} \mathrm{44-46}{ }^{\circ} \mathrm{C}$; IR (neat) 3053,2942 , 2839, 2152, 1592, 1502, 1264, 913, 735, $703 \mathrm{~cm}^{-1}$; HRMS (ESI): Mass calculated for $\mathrm{C}_{33} \mathrm{H}_{26} \mathrm{SiNa}$ $[\mathrm{M}+\mathrm{Na}]^{+}, 473.1696$ Found $[\mathrm{M}+\mathrm{Na}]^{+}, 473.1707 ;[\alpha]^{23}=-3.1\left(\mathrm{c} 0.48, \mathrm{CHCl}_{3}\right)$.

\section{General procedure for optimization of Barbier-type coupling (Table 1)}<smiles>[X]Cc1ccc2ccccc2c1-c1c(-c2ccccc2)ccc2ccccc12</smiles>

2<smiles>PSCc1ccc2ccccc2c1-c1c(P)cccc1-c1cccc2ccccc12</smiles>

$1 \mathrm{a}$<smiles>Pc1cccc(-c2ccccc2)c1-c1c(CSc2ccccc2)ccc2ccccc12</smiles>

phenyl((2'-phenyl-[1,1'-binaphthalen]-2-yl)methyl)silane (1a): To a flame dried $8 \mathrm{~mL}$ vial was added magnesium powder $(7.3 \mathrm{mg}, 0.3 \mathrm{mmol}, 3.0$ equiv.), sealed with a screw cap, and purged with argon followed by the addition of THF $(0.2 \mathrm{~mL})$. To a separate flame dried $8 \mathrm{~mL}$ vial was added 2 ( $0.1 \mathrm{mmol}, 1.0$ equiv.), THF (0.3 $\mathrm{mL})$ and phenylchlorosilane (3) $(20 \mu \mathrm{L}, 0.15 \mathrm{mmol}, 1.5$ equiv.). The reaction vial containing the magnesium power was placed in a sonicator water bath and 
subjected to sonication at $23^{\circ} \mathrm{C}$. Immediately after beginning sonication, 1,2-dibromoethane $(4.3 \mu \mathrm{L}, 0.05$ mmol, 0.5 equiv.) was added to the reaction vial followed by the addition of the solution containing $\mathbf{2}$, phenylchlorosilane (3) and THF. The reaction mixture was then sonicated for 30 mins at $23^{\circ} \mathrm{C}$. After 30 min, the reaction was quenched with saturated $\mathrm{NH}_{4} \mathrm{Cl}$ aq) $(1.0 \mathrm{~mL})$, extracted with $\mathrm{Et}_{2} \mathrm{O}(3 \mathrm{x})$, dried over $\mathrm{Na}_{2} \mathrm{SO}_{4}$ and concentrated in vacuo. Reaction yields for table 1, entries 1 and 2 were determined via ${ }^{1} \mathrm{H}$ NMR analysis of the crude material using 1,3,5-trimethoxy benzene as an internal standard. Products for table 1, entries 3-5 were purified via flash column chromatography on silica gel (hexanes to 95:5 hexanes: $\left.\mathrm{Et}_{2} \mathrm{O}\right)$ to afford a white solid. Table 1,entry $3=(42.3 \mathrm{mg}, 0.094 \mathrm{mmol}, 94 \%)$, table 1 , entry $4=$ (36.3 mg, $0.081 \mathrm{mmol}, 81 \%)$, table 1, entry $5=(40.6 \mathrm{mg}, 0.090 \mathrm{mmol}, 90 \%) .{ }^{1} \mathrm{H} \mathrm{NMR}(400 \mathrm{MHz} \mathrm{CDCl})_{3}$ $\delta 8.03(\mathrm{~d}, J=8.4 \mathrm{~Hz}, 1 \mathrm{H}), 7.95(\mathrm{~d}, J=8.1 \mathrm{~Hz}, 1 \mathrm{H}), 7.82(\mathrm{~d}, J=8.2 \mathrm{~Hz}, 1 \mathrm{H}), 7.71(\mathrm{~d}, J=8.5 \mathrm{~Hz}, 1 \mathrm{H}), 7.68$ $(\mathrm{d}, J=8.5 \mathrm{~Hz}, 1 \mathrm{H}), 7.43-7.47(\mathrm{~m}, 1 \mathrm{H}), 7.35-7.39(\mathrm{~m}, 1 \mathrm{H}), 7.28-7.32(\mathrm{~m}, 1 \mathrm{H}), 7.16-7.25(\mathrm{~m}, 8 \mathrm{H}), 6.98-7.13$ $(\mathrm{m}, 6 \mathrm{H}), 3.96$ (ddd, $J=6.8,4.7,3.4 \mathrm{~Hz}, 1 \mathrm{H}), 3.89-3.92(\mathrm{~m}, 1 \mathrm{H}), 2.12$ (ddd, $J=14.3,4.7,3.0 \mathrm{~Hz}, 1 \mathrm{H}), 2.04$ (ddd, $J=14.3,4.8,3.4 \mathrm{~Hz}, 1 \mathrm{H}) .{ }^{13} \mathrm{C} \operatorname{NMR}\left(100 \mathrm{MHz}, \mathrm{CDCl}_{3}\right) \delta 141.8,139.4,136.1,135.2,134.8,134.4$, 133.7, 133.4, 133.0, 132.2, 131.3, 129.7, 129.1, 128.6, 128.4, 128.1, 128.0, 127.9, 127.8, 127.6, 127.5, 126.7, 126.6, 126.4, 126.3, 126.0, 124.7, 18.2; mp 44-46 ํ; IR (neat) 3053, 2942, 2839, 2152, 1592, 1502, 1264, 913, 735, $703 \mathrm{~cm}^{-1}$; HRMS (ESI): Mass calculated for $\mathrm{C}_{33} \mathrm{H}_{26} \mathrm{SiNa}[\mathrm{M}+\mathrm{Na}]^{+}$, $473.1696 \mathrm{Found}$ $[\mathrm{M}+\mathrm{Na}]^{+}, 473.1707 ;[\alpha]^{23}=-3.1\left(\mathrm{c} 0.48, \mathrm{CHCl}_{3}\right)$.

\section{General procedure for preparation of BINOL-based silanes (Table 2)}<smiles>BrCc1ccc2ccccc2c1-c1c(-c2ccccc2)ccc2ccccc12</smiles>

2

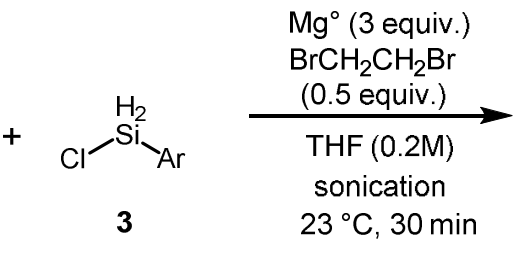

$23^{\circ} \mathrm{C}, 30 \mathrm{~min}$

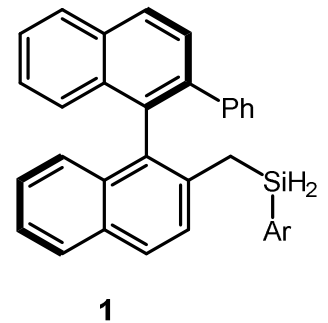

1

To a flame dried $8 \mathrm{~mL}$ vial was added magnesium powder (14.6 mg, $0.6 \mathrm{mmol}, 3.0$ equiv.), sealed with a screw cap, and purged with argon followed by the addition of THF $(0.4 \mathrm{~mL})$. To a separate flame dried 8 $\mathrm{mL}$ vial was added 2 (84.7 mg, $0.2 \mathrm{mmol}, 1.0$ equiv.), THF $(0.6 \mathrm{~mL})$ and arylchlorosilane $(0.3 \mathrm{mmol}, 1.5$ equiv.). The reaction vial containing the magnesium power was placed in a sonicator water bath and subjected to sonication at $23{ }^{\circ} \mathrm{C}$. Immediately after beginning sonication, 1,2-dibromoethane $(8.6 \mu \mathrm{L}, 0.1$ mmol, 0.5 equiv.) was added to the reaction vial followed by the addition of the solution containing 2 , arylchlorosilane and THF. The reaction mixture was then sonicated for $30 \mathrm{mins}$ at $23^{\circ} \mathrm{C}$. After $30 \mathrm{~min}$, the reaction was quenched with saturated $\mathrm{NH}_{4} \mathrm{Cl}_{(\mathrm{aq})}(2.5 \mathrm{~mL})$, extracted with $\mathrm{Et}_{2} \mathrm{O}(3 \mathrm{x})$, dried over $\mathrm{Na}_{2} \mathrm{SO}_{4}$ and concentrated in vacuo. Products were purified via flash column chromatography on silica gel using the conditions stated below.<smiles>Pc1cccc(-c2c(CSc3ccccc3)ccc3ccccc23)c1-c1ccccc1</smiles>

phenyl((2'-phenyl-[1,1'-binaphthalen]-2-yl)methyl)silane (1a): Purified via flash column chromatography on silica gel (hexanes to $95: 5$ hexanes: $\mathrm{Et}_{2} \mathrm{O}$ ) to afford the title compound as a white solid $\left(84.7 \mathrm{mg}, 0.188 \mathrm{mmol}, 94 \%\right.$ yield). ${ }^{1} \mathrm{H}$ NMR (400 $\left.\mathrm{MHz}, \mathrm{CDCl}_{3}\right) \delta 8.03(\mathrm{~d}, J=8.4 \mathrm{~Hz}, 1 \mathrm{H}), 7.95(\mathrm{~d}, J=8.1 \mathrm{~Hz}, 1 \mathrm{H}), 7.82(\mathrm{~d}, J=8.2$ $\mathrm{Hz}, 1 \mathrm{H}), 7.71(\mathrm{~d}, J=8.5 \mathrm{~Hz}, 1 \mathrm{H}), 7.68(\mathrm{~d}, J=8.5 \mathrm{~Hz}, 1 \mathrm{H}), 7.43-7.47(\mathrm{~m}, 1 \mathrm{H}), 7.35-$ $7.39(\mathrm{~m}, 1 \mathrm{H}), 7.28-7.32(\mathrm{~m}, 1 \mathrm{H}), 7.16-7.25(\mathrm{~m}, 8 \mathrm{H}), 6.98-7.13(\mathrm{~m}, 6 \mathrm{H}), 3.96$ (ddd, $J$ $=6.8,4.7,3.4 \mathrm{~Hz}, 1 \mathrm{H}), 3.89-3.92(\mathrm{~m}, 1 \mathrm{H}), 2.12(\mathrm{ddd}, J=14.3,4.7,3.0 \mathrm{~Hz}, 1 \mathrm{H})$, 2.04 (ddd, $J=14.3,4.8,3.4 \mathrm{~Hz}, 1 \mathrm{H}) .{ }^{13} \mathrm{C}$ NMR $\left(100 \mathrm{MHz}, \mathrm{CDCl}_{3}\right) \delta 141.8,139.4,136.1,135.2,134.8$, 134.4, 133.7, 133.4, 133.0, 132.2, 131.3, 129.7, 129.1, 128.6, 128.4, 128.1, 128.0, 127.9, 127.8, 127.6, 127.5, 126.7, 126.6, 126.4, 126.3, 126.0, 124.7, 18.2; mp 44-46 우; IR (neat) 3053, 2942, 2839, 2152, 1592, 1502, 1264, 913, 735, $703 \mathrm{~cm}^{-1}$; HRMS (ESI): Mass calculated for $\mathrm{C}_{33} \mathrm{H}_{26} \mathrm{SiNa}[\mathrm{M}+\mathrm{Na}]^{+}, 473.1696$ Found $[\mathrm{M}+\mathrm{Na}]^{+}, 473.1707 ;[\alpha]^{23}=-3.1\left(\mathrm{c} 0.48, \mathrm{CHCl}_{3}\right)$. 
<smiles>COc1ccc([SiH2]Cc2ccc3ccccc3c2-c2c(-c3ccccc3)ccc3ccccc23)cc1</smiles>
hexanes: $\left.\mathrm{Et}_{2} \mathrm{O}\right)$ to afford the title compound as a white solid $(84.6 \mathrm{mg}, 0.179 \mathrm{mmol}$, $88 \%$ yield). ${ }^{1} \mathrm{H}$ NMR (400 MHz, $\left.\mathrm{CDCl}_{3}\right) \delta 8.03(\mathrm{~d}, J=8.3 \mathrm{~Hz}, 1 \mathrm{H}), 7.94$ (d, J= 8.2 $\mathrm{Hz}, 1 \mathrm{H}), 7.81(\mathrm{~d}, J=8.1 \mathrm{~Hz}, 1 \mathrm{H}), 7.71(\mathrm{~d}, J=8.5 \mathrm{~Hz}, 1 \mathrm{H}), 7.67(\mathrm{~d}, J=8.5 \mathrm{~Hz}, 1 \mathrm{H})$, 7.43-7.47 (m, 1H), 7.34-7.38 (m, 1H), 7.16-7.24 (m, 4H), 6.98-7.10 (m, 8H), 6.73$6.75(\mathrm{~m}, 2 \mathrm{H}), 3.94(\mathrm{ddd}, J=6.8,4.5,3.4 \mathrm{~Hz}, 1 \mathrm{H}), 3.90(\mathrm{ddd}, J=6.7,4.6,3.1 \mathrm{~Hz}$, 1H), 3.77 (s, 3H), 2.08 (ddd, $J=14.2,4.5,3.1 \mathrm{~Hz}, 1 \mathrm{H}$ ), 2.00 (ddd, $J=14.2,4,7,3.5$ $\mathrm{Hz}, 1 \mathrm{H}) .{ }^{13} \mathrm{C}$ NMR $\left(100 \mathrm{MHz} \mathrm{CDCl}_{3}\right) \delta 160.9,141.8,139.4,136.7,136.3,134.8$, 126.8, 126.6, 134.5, 133.7, 133.4, 133.0, 131.3, 129.1, 128.6, 128.3, 128.1, 127.9, 127.8, 127.6, 126.8, 126.6, 126.3, 125.9, 124.6, 122.8, 113.8, 55.1, 18.6; mp 54-56 ㅇ; IR (neat) 3052, 2954, 2137, 1593, 1501, 1280, 1247, 850, 747, $700 \mathrm{~cm}^{-1}$; HRMS (ESI): Mass calculated for $\mathrm{C}_{34} \mathrm{H}_{28} \mathrm{OSiNa}[\mathrm{M}+\mathrm{Na}]^{+}$, 503.1802 Found $[\mathrm{M}+\mathrm{Na}]^{+}, 503.1803 ;[\alpha]^{23}=-23.9\left(\mathrm{c} 0.56, \mathrm{CHCl}_{3}\right)$.

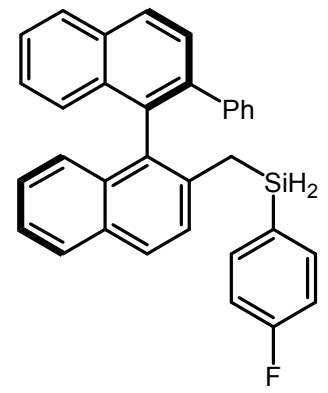

(4-fluorophenyl)((2'-phenyl-[1,1'-binaphthalen]-2-yl)methyl)silane (1c): Purified via flash column chromatography on silica gel (hexanes to 90:10 hexanes: $\mathrm{Et}_{2} \mathrm{O}$ ) to afford the title compound as a white solid (84.2 mg, $0.179 \mathrm{mmol}, 90 \%$ yield). ${ }^{1} \mathrm{H}$ $\operatorname{NMR}\left(400 \mathrm{MHz}, \mathrm{CDCl}_{3}\right) \delta 8.04(\mathrm{~d}, J=8.3 \mathrm{~Hz}, 1 \mathrm{H}), 7.95(\mathrm{~d}, J=8.1 \mathrm{~Hz}, 1 \mathrm{H}), 7.83$ (d, $J=8.1 \mathrm{~Hz}, 1 \mathrm{H}), 7.72(\mathrm{~d}, J=8.5 \mathrm{~Hz}, 1 \mathrm{H}), 7.69(\mathrm{~d}, J=8.5 \mathrm{~Hz}, 1 \mathrm{H}), 7.43-7.47(\mathrm{~m}$, $1 \mathrm{H}), 7.36-7.40(\mathrm{~m}, 1 \mathrm{H}), 7.16-7.27(\mathrm{~m}, 4 \mathrm{H}), 6.99-7.13(\mathrm{~m}, 8 \mathrm{H}), 6.85-6.90(\mathrm{~m}, 2 \mathrm{H})$, 3.91-3.98 (m, 2H), $2.10(\mathrm{ddd}, J=14.4,4.2,3.4 \mathrm{~Hz}, 1 \mathrm{H}), 2.01(\mathrm{~m}, 1 \mathrm{H}) .{ }^{13} \mathrm{C} \mathrm{NMR}$ $\left(100 \mathrm{MHz} \mathrm{CDCl}_{3}\right) \delta 164.1\left(\mathrm{~d}, J_{\mathrm{CF}}=248.6 \mathrm{~Hz}\right), 141.7,139.4,137.1\left(\mathrm{~d}, J_{\mathrm{CF}}=7.8\right.$ $\mathrm{Hz})$, 135.8, 134.8, 134.4, 133.8, 133.4, 133.0, 131.3, 129.1, 128.6, 128.4, 128.1, $127.9\left(\mathrm{~d}, J_{\mathrm{CF}}=2.8 \mathrm{~Hz}\right), 127.8,127.6,127.5,126.8,126.7,126.4,126.3,126.0$, 124.7, $115.2\left(d, J_{C F}=20.0 \mathrm{~Hz}\right.$ ), 18.3; mp 47-48 ํㅜ; IR (neat) 3055, 2921, 2148, 1588, 1495, 1162, 905, 867, 742, 728, $650 \mathrm{~cm}^{-1}$; HRMS (ESI): Mass calculated for $\mathrm{C}_{33} \mathrm{H}_{25} \mathrm{FSiNa}[\mathrm{M}+\mathrm{Na}]^{+}, 491.1602 \mathrm{Found}$ $[\mathrm{M}+\mathrm{Na}]^{+}, 491.1597 ;[\alpha]^{23}=5.6\left(\mathrm{c} 0.40, \mathrm{CHCl}_{3}\right)$.

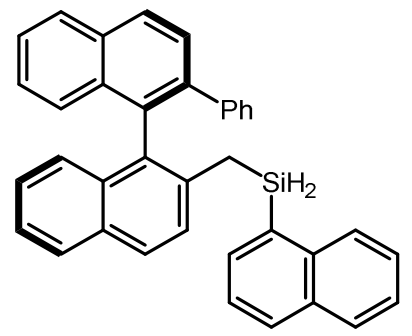

naphthalen-1-yl((2'-phenyl-[1,1'-binaphthalen]-2-yl)methyl)silane $\quad$ (1d): Purified via flash column chromatography on silica gel (hexanes to 95:5 hexanes: $\left.\mathrm{Et}_{2} \mathrm{O}\right)$ to afford the title compound as a white solid (95.5 mg, 0.191 mmol, $95 \%$ yield). ${ }^{1} \mathrm{H}$ NMR $\left(400 \mathrm{MHz}, \mathrm{CDCl}_{3}\right) \delta 8.07(\mathrm{~d}, J=8.5 \mathrm{~Hz}, 1 \mathrm{H}), 7.98$ $(\mathrm{d}, J=8.2 \mathrm{~Hz}, 1 \mathrm{H}), 7.67-7.84(\mathrm{~m}, 5 \mathrm{H}), 7.36-7.49(\mathrm{~m}, 4 \mathrm{H}), 7.19-7.32(\mathrm{~m}, 8 \mathrm{H})$, 6.95-7.05 $(\mathrm{m}, 5 \mathrm{H}), 4.30-4.34(\mathrm{~m}, 1 \mathrm{H}), 4.18-4.21(\mathrm{~m}, 1 \mathrm{H}), 2.24-2.29(\mathrm{~m}, 1 \mathrm{H})$, 2.11 (ddd, $J=14.2,5.8,3.2 \mathrm{~Hz}, 1 \mathrm{H}) .{ }^{13} \mathrm{C}$ NMR $\left(100 \mathrm{MHz}, \mathrm{CDCl}_{3}\right) \delta 141.8$, $139.4,136.9,136.3,135.9,134.8,134.5,133.6,133.5,133.1,133.0,131.4$, $130.9,130.7,129.1,128.8,128.7,128.4,128.1,128.0,127.8,127.7,127.6$, $127.5,126.8,126.6,126.4,126.3,126.2,126.1,125.8,125.2,124.7,18.7$; mp 65-68 ㅇ; IR (neat) 3054, 2946, 2144, 1587, 1497, 1229, 1161, 912, 743, $700 \mathrm{~cm}^{-1}$; HRMS (ESI): Mass calculated for $\mathrm{C}_{37} \mathrm{H}_{28} \mathrm{SiNa}$ $[\mathrm{M}+\mathrm{Na}]^{+}, 523.1852$ Found $[\mathrm{M}+\mathrm{Na}]^{+}, 523.1850 ;[\mathrm{\alpha}]_{\mathrm{D}}^{23}=18.6\left(\mathrm{c} 0.50, \mathrm{CHCl}_{3}\right)$.<smiles>Cc1cc(C)c([SiH2]Cc2ccc3ccccc3c2-c2c(-c3ccccc3)ccc3ccccc23)c(C)c1</smiles>

mesityl((2'-phenyl-[1,1'-binaphthalen]-2-yl)methyl)silane (1e): Purified via flash column chromatography on silica gel (hexanes to 95:5 hexanes: $\left.\mathrm{Et}_{2} \mathrm{O}\right)$ to afford the title compound as a white solid $(91.9 \mathrm{mg}$, $0.187 \mathrm{mmol}, 93 \%$ yield). ${ }^{1} \mathrm{H}$ NMR $\left(400 \mathrm{MHz}, \mathrm{CDCl}_{3}\right) \delta 8.01$ (d, $J=8.5 \mathrm{~Hz}$, $1 \mathrm{H}), 7.93(\mathrm{~d}, J=8.2 \mathrm{~Hz}, 1 \mathrm{H}), 7.83(\mathrm{~d}, J=8.1 \mathrm{~Hz}, 1 \mathrm{H}), 7.73(\mathrm{~d}, J=8.4 \mathrm{~Hz}$, $1 \mathrm{H}), 7.65(\mathrm{~d}, J=8.5 \mathrm{~Hz}, 1 \mathrm{H}), 7.42-7.46(\mathrm{~m}, 1 \mathrm{H}), 7.35-7.39(\mathrm{~m}, 1 \mathrm{H}), 7.16-$ $7.25(\mathrm{~m}, 4 \mathrm{H}), 6.96-7.06(\mathrm{~m}, 6 \mathrm{H}), 6.66(\mathrm{~s}, 2 \mathrm{H}), 4.23-4.27(\mathrm{~m}, 1 \mathrm{H}), 3.88-3.91(\mathrm{~m}, 1 \mathrm{H}), 2.19(\mathrm{~s}, 3 \mathrm{H}), 1.94-$ $2.06(\mathrm{~m}, 2 \mathrm{H}), 1.90(\mathrm{~s}, 6 \mathrm{H}) .{ }^{13} \mathrm{C} \mathrm{NMR}\left(100 \mathrm{MHz}, \mathrm{CDCl}_{3}\right) \delta 144.7,141.8,139.7,139.4,136.6,134.8,134.6$, $133.5,133.0,131.3,129.1,128.9,128.6,128.2$, 128.1, 127.84, 127.82, 127.80, 127.7, 127.5, 126.9, 
126.8, 126.6, 126.3, 126.2, 125.9, 124.6, 23.1, 21.2, 18.4; mp 63-65 우; IR (neat) 3054, 2923, 2252, 2153, 1603, 964, 905, 728, $650 \mathrm{~cm}^{-1}$; HRMS (ESI): Mass calculated for $\mathrm{C}_{36} \mathrm{H}_{32} \mathrm{SiNa}[\mathrm{M}+\mathrm{Na}]^{+}, 515.2165$ Found $[\mathrm{M}+\mathrm{Na}]^{+}, 515.2167 ;[\alpha]^{23}=12.9\left(\mathrm{c} \mathrm{0.43}, \mathrm{CHCl}_{3}\right)$.

\section{General procedure for preparation of benzylic silanes (Table 2)}
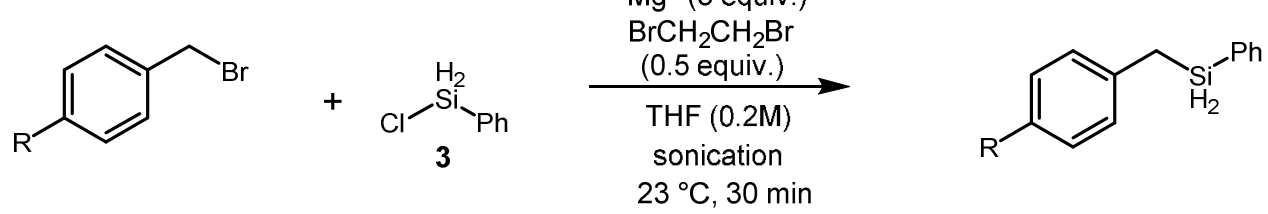

To a flame dried $8 \mathrm{~mL}$ vial was added magnesium powder $(29.0 \mathrm{mg}, 1.2 \mathrm{mmol}, 3.0$ equiv.), sealed with a screw cap, and purged with argon followed by the addition of THF $(0.8 \mathrm{~mL})$. To a separate flame dried 8 $\mathrm{mL}$ vial was added the benzyl bromide $(0.4 \mathrm{mmol}, 1.0$ equiv.), THF $(1.2 \mathrm{~mL})$ and phenylchlorosilane $(80$ $\mu \mathrm{L}, 0.6 \mathrm{mmol}, 1,5$ equiv.). The reaction vial containing the magnesium power was placed in a sonicator water bath and subjected to sonication at $23{ }^{\circ} \mathrm{C}$. Immediately after beginning sonication, 1,2dibromoethane $(17.0 \mu \mathrm{L}, 0.2 \mathrm{mmol}, 0.5$ equiv.) was added to the reaction vial followed by the addition of the solution containing the benzyl bromide, phenylchlorosilane and THF. The reaction mixture was then sonicated for 30 mins at $23{ }^{\circ} \mathrm{C}$. After $30 \mathrm{~min}$, the reaction was quenched with saturated $\mathrm{NH}_{4} \mathrm{Cl}($ aq) $(4.0$ $\mathrm{mL}$ ), extracted with $\mathrm{Et}_{2} \mathrm{O}(3 \mathrm{x})$, dried over $\mathrm{Na}_{2} \mathrm{SO}_{4}$ and concentrated in vacuo. Products were purified via flash column chromatography on silica gel using the conditions stated below.<smiles>c1ccc(C[SH+]c2ccccc2)cc1</smiles>

benzyl(phenyl)silane (1f): Purified via short silica gel plug (hexanes) to afford the title compound as a colorless oil (53.2 $\mathrm{mg}, 0.268 \mathrm{mmol}, 67 \%) .{ }^{1} \mathrm{H}$ NMR $\left(400 \mathrm{MHz}, \mathrm{CDCl}_{3}\right) \delta$ 7.48-7.51 (m, 2H), 7.32-7.42 (m, 3H), 7.21-7.24 (m, 2H), 7.07-7.13 (m, 3H), 4.41 $(\mathrm{t}, J=$ $3.9 \mathrm{~Hz}, 2 \mathrm{H}), 2.47(\mathrm{t}, \mathrm{J}=3.9 \mathrm{~Hz}, 2 \mathrm{H}) .{ }^{13} \mathrm{C}$ NMR $\left(100 \mathrm{MHz}, \mathrm{CDCl}_{3}\right) \delta 139.1,135.4,131.9,129.9,128.6$, $128.5,128.1,124.9,20.2$. All spectral data matched previously reported. ${ }^{9}$<smiles>Fc1ccc(C[HgH2]c2ccccc2)cc1</smiles>

(4-fluorobenzyl)(phenyl)silane (1g): Purified via short silica gel plug (pentanes) to afford the title compound as a colorless oil $(50.4 \mathrm{mg}, 0.233 \mathrm{mmol}, 58 \%){ }^{1} \mathrm{H}$ NMR $\left(400 \mathrm{MHz}, \mathrm{CDCl}_{3}\right) \delta$ 7.46-7.49 (m, 2H), 7.32-7.43 (m, 3H), 6.98-7.03 (m, 2H), 6.88$6.94(\mathrm{~m}, 2 \mathrm{H}), 4.39(\mathrm{t}, J=3.8 \mathrm{~Hz}, 2 \mathrm{H}), 2.43(\mathrm{t}, J=3.8 \mathrm{~Hz}, 2 \mathrm{H}) .{ }^{13} \mathrm{C} \mathrm{NMR}(100 \mathrm{MHz}$, $\left.\mathrm{CDCl}_{3}\right) \delta 160.8\left(\mathrm{~d}, \mathrm{~J}_{\mathrm{CF}}=242.3 \mathrm{~Hz}\right), 135.4,134.6\left(\mathrm{~d}, \mathrm{~J}_{\mathrm{CF}}=3.4 \mathrm{~Hz}\right), 131.6,130.0,129.7\left(\mathrm{~d}, \mathrm{~J}_{\mathrm{CF}}=2.8 \mathrm{~Hz}\right)$, 128.2, 115.4 (d, $J_{\mathrm{CF}}=21.3 \mathrm{~Hz}$ ), 19.3; IR (neat) 3053, 2942, 2841, 2142, 1591, 1506, 1223, 1076, 906, 870, $730 \mathrm{~cm}^{-1}$; HRMS (ESI): Mass calculated for $\mathrm{C}_{13} \mathrm{H}_{13} \mathrm{FSiNa}[\mathrm{M}+\mathrm{Na}]^{+}, 239.0663$ Found [M+Na] $]^{+}$ 239.0653<smiles>COc1ccc(C[HgH2]c2ccccc2)cc1</smiles>

(4-methoxybenzyl)(phenyl)silane (1h): Purified via short silica gel column (97:3 pentanes: $\left.\mathrm{Et}_{2} \mathrm{O}\right)$ to afford the title compound as a colorless oil $(61.2 \mathrm{mg}, 0.268$ $\mathrm{mmol}, 67 \%){ }^{1} \mathrm{H}$ NMR $\left(400 \mathrm{MHz}, \mathrm{CDCl}_{3}\right) \delta$ 7.48-7.50 (m, 2H), 7.31-7.42 (m, 3H), 6.99-7.01 (m, 2H), 6.78-6.80 (m, 2H), $4.40(\mathrm{t}, J=3.9 \mathrm{~Hz}, 2 \mathrm{H}), 3.77(\mathrm{~s}, 3 \mathrm{H}), 2.40$ (t, $J=3.9 \mathrm{~Hz}, 2 \mathrm{H}) .{ }^{13} \mathrm{C}$ NMR $\left(100 \mathrm{MHz}, \mathrm{CDCl}_{3}\right) \delta 157.2,135.4,132.1,130.9,129.9,129.4,128.1,114.1$, 55.4, 18.9; IR (neat) 3053, 2941, 2838, 2138, 1591, 1508, 1244, 906, 869, 730, $702 \mathrm{~cm}^{-1}$; HRMS (ESI): Mass calculated for $\mathrm{C}_{14} \mathrm{H}_{16} \mathrm{OSiNa}[\mathrm{M}+\mathrm{Na}]^{+}, 251.0863$ Found $[\mathrm{M}+\mathrm{Na}]^{+}, 251.0865$<smiles>CC([Hg]c1ccccc1)c1ccccc1</smiles>

phenyl(1-phenylethyl)silane (1i): Purified via short silica gel plug (99:1 hexanes: $\left.\mathrm{Et}_{2} \mathrm{O}\right)$ to afford the title compound as a colorless oil $(66.2 \mathrm{mg}, 0.312 \mathrm{mmol}, 78 \%){ }^{1} \mathrm{H}$ NMR $\left(400 \mathrm{MHz}, \mathrm{CDCl}_{3}\right) \delta$ 7.37-7.43 (m, 3H), 7.24-7.34 (m, 4H), 7.09-7.15 (m, 3H). $4.34(\mathrm{~d}, J$ $=3.2,2 \mathrm{H}), 2.59-2.67(\mathrm{~m}, 1 \mathrm{H}), 1.47(\mathrm{~d}, J=7.5,3 \mathrm{H}) \cdot{ }^{13} \mathrm{C} \mathrm{NMR}\left(100 \mathrm{MHz}, \mathrm{CDCl}_{3}\right) \delta$ $144.7,135.8,131.5,129.9,128.5,128.0,127.3,125.2,25.5,16.5$. All spectral data matched previously reported. ${ }^{10}$ 


\section{Synthesis of 5 (Scheme 3, eq 2):}
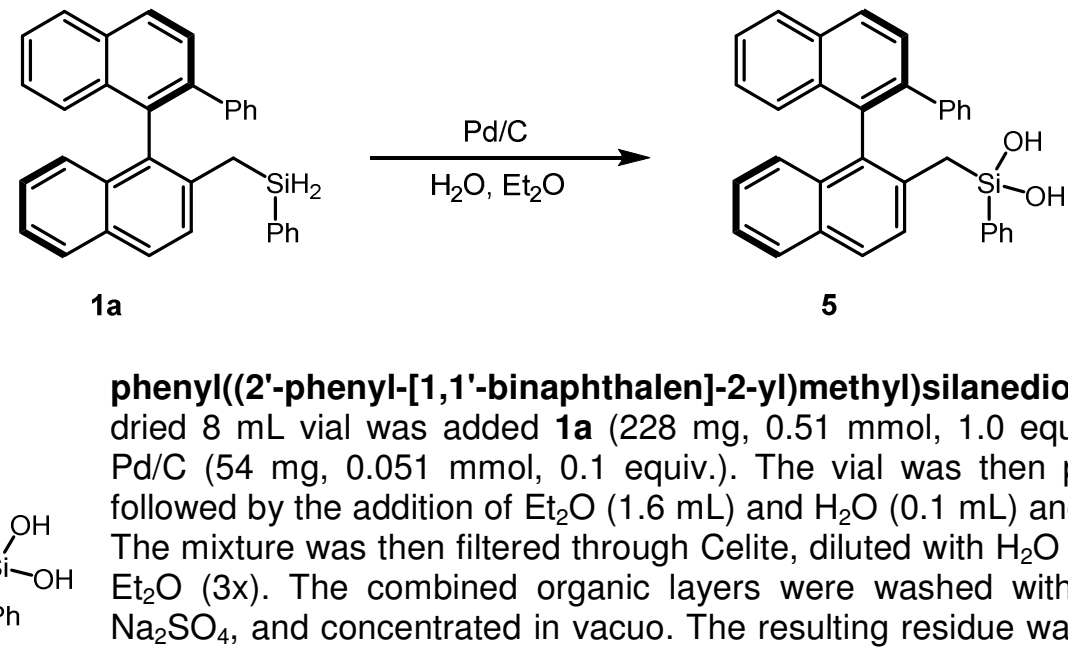

$1 \mathrm{a}$<smiles>O[Si](O)(Cc1ccc2ccccc2c1-c1c(-c2ccccc2)ccc2ccccc12)c1ccccc1</smiles>

phenyl((2'-phenyl-[1,1'-binaphthalen]-2-yl)methyl)silanediol (5) : To a flame dried $8 \mathrm{~mL}$ vial was added $1 \mathrm{a}(228 \mathrm{mg}, 0.51 \mathrm{mmol}, 1.0$ equiv.) and $10 \mathrm{wt}$ \% $\mathrm{Pd} / \mathrm{C}$ (54 mg, $0.051 \mathrm{mmol}, 0.1$ equiv.). The vial was then purged with argon followed by the addition of $\mathrm{Et}_{2} \mathrm{O}(1.6 \mathrm{~mL})$ and $\mathrm{H}_{2} \mathrm{O}(0.1 \mathrm{~mL})$ and stirred overnight. The mixture was then filtered through Celite, diluted with $\mathrm{H}_{2} \mathrm{O}$ and extracted with $\mathrm{Et}_{2} \mathrm{O}(3 \mathrm{x})$. The combined organic layers were washed with brine, dried with $\mathrm{Na}_{2} \mathrm{SO}_{4}$, and concentrated in vacuo. The resulting residue was purified via flash column chromatography on silica gel (hexanes to 50:50 hexanes: $\mathrm{t}_{2} \mathrm{O}$ ) to afford the title compound as a white solid (147 mg, $0.305 \mathrm{mmol}, 60 \%)$. The silanediol exists as a 9:1 complex with $\mathrm{Et}_{2} \mathrm{O}$. ${ }^{1} \mathrm{H} \mathrm{NMR}(400$ $\left.\mathrm{MHz} \mathrm{CDCl}_{3}\right) \delta 8.05(\mathrm{~d}, J=8.5 \mathrm{~Hz}, 1 \mathrm{H}), 7.98(\mathrm{~d}, J=8.2 \mathrm{~Hz}, 1 \mathrm{H}), 7.84(\mathrm{~d}, J=8.1 \mathrm{~Hz}, 1 \mathrm{H}), 7.69-7.72(\mathrm{~m}$, 2H), 7.46-7.50 (m, 1H), 7.34-7.41 (m, 4H), 7.21-7.29 (m, 6H), 7.02-7.13 (m, 6H), $2.10(\mathrm{~d}, \mathrm{~J}=14.7 \mathrm{~Hz}$,

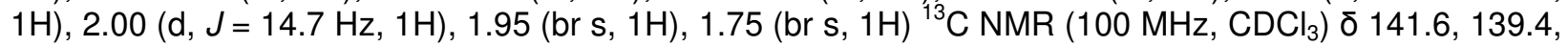
$135.1,135.0,134.53,134.50,133.9,133.7,133.3,133.1,131.3,130.4,129.2,128.9,128.6,128.54$, 128.56, 128.4, 128.2, 127.92, 127.90, 127.8, 127.0, 126.8, 126.7, 126.5, 126.1, 124.8, 22.7; mp 87-88 을 IR (neat) 3345, 3053, 2974, 2862, 1382, 1116, 822, 763, $700 \mathrm{~cm}^{-1}$; HRMS (ESI): Mass calculated for $\mathrm{C}_{33} \mathrm{H}_{26} \mathrm{O}_{2} \mathrm{SiNa}[\mathrm{M}+\mathrm{Na}]^{+}, 505.1594$ Found $[\mathrm{M}+\mathrm{Na}]^{+}, 505.1586 ;[\alpha]^{23}=5.6$ (c 0.43, $\mathrm{CHCl}_{3}$ ).

\section{Synthesis of 6 (Scheme 3, eq 3):}<smiles>CC([SiH2]c1ccccc1)c1ccccc1</smiles>

$1 \mathbf{i}$

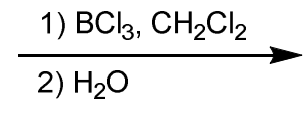

phenyl(1-phenylethyl)silanol (6): To a flame dried $8 \mathrm{~mL}$ vial was added $1 \mathbf{i}(63.7 \mathrm{mg}$, $0.3 \mathrm{mmol}, 1.0$ equiv.) and $\mathrm{CH}_{2} \mathrm{Cl}_{2}(0.9 \mathrm{~mL})$ under argon atmosphere. $\mathrm{BCl}_{3}(1.0 \mathrm{M}$ in $\mathrm{CH}_{2} \mathrm{Cl}_{2}, 0.3 \mathrm{~mL}, 0.3 \mathrm{mmol}, 1.0$ equiv.) was added dropwise to the reaction vial and stirred at $23{ }^{\circ} \mathrm{C}$ for $6 \mathrm{~h} . \mathrm{H}_{2} \mathrm{O}(0.5 \mathrm{~mL})$ was then added to the reaction mixture and stirred overnight. The reaction was then diluted with $\mathrm{H}_{2} \mathrm{O}$ and extracted with $\mathrm{Et}_{2} \mathrm{O}(3 \mathrm{x})$. The combined organic layers were washed with brine, dried with $\mathrm{Na}_{2} \mathrm{SO}_{4}$, and concentrated in vacuo. The resulting residue was purified via flash column chromatography on silica gel (hexanes to 70:30 hexanes: $\mathrm{Et}_{2} \mathrm{O}$ ) to afford the title compound as a colorless oil as a 1:1 mixture of diastereomers (43.3 mg, $0.183 \mathrm{mmol}, 60 \%)$. The silanol product exists as a 9:1 complex with $\mathrm{Et}_{2} \mathrm{O} .{ }^{1} \mathrm{H} \mathrm{NMR}\left(400 \mathrm{MHz}^{\mathrm{CDCl}} \mathrm{CDC}_{3}\right.$ 7.50-7.52 (m, 1H), 7.23-7.45 (m, 6H), 7.07-7.16 (m, 3H), $4.96(\mathrm{~d}, J=1.6 \mathrm{~Hz}, 0.5 \mathrm{H}), 4.93(\mathrm{~d}, \mathrm{~J}=2.6 \mathrm{~Hz}$, $0.5 \mathrm{H}), 2.52-2.58(\mathrm{~m}, 1 \mathrm{H}), 1.94(\mathrm{br} \mathrm{s}, 0.5 \mathrm{H}), 1.88(\mathrm{br} \mathrm{s}, 0.5 \mathrm{H}), 1.44$ (d, J = 7.6 Hz, $1.5 \mathrm{H}), 1.40(\mathrm{~d}, J=7.6$ $\mathrm{Hz}, 1.5 \mathrm{H}){ }^{13} \mathrm{C}$ NMR $\left(100 \mathrm{MHz}, \mathrm{CDCl}_{3}\right) \delta$ 143.3, 143.2, 134.23, 134.20, 134.1, 130.5, 130.4, 128.6, 128.5, 128.0, 127.9, 127.6, 127.5, 125.3, 125.2, 29.2, 29.1, 14.3, 14.0; IR (neat) 3293, 3052, 2956, 2870, 2126, 1598, 1264, 1117, 822, 735, $699 \mathrm{~cm}^{-1}$; HRMS (ESI): Mass calculated for $\mathrm{C}_{14} \mathrm{H}_{16} \mathrm{OSiNa}[\mathrm{M}+\mathrm{Na}]^{+}, 251.0863$ Found $[\mathrm{M}+\mathrm{Na}]^{+}, 251.0859$; 
Supporting Information

Page S14

\section{References:}

1. Manoso, A. S.; Ahn, C.; Soheili, A.; Handy, C. J.; Correia, R.; Seganish, W. M.; DeShang, P.; J. Org. Chem. 2004, 69, 8305-8314

2. Ruediger, C.; Beruda, H.; Schmidbaur, H. Chem. Ber. 1992, 125, 1401-1403

3. Bauer, J.O.; Strohmann, C. Chem. Commun. 2012, 48, 7212-7214

4. Boudin, A.; Cerveau, G.; Chuit, C.; Corriu, R.J.P.; Reye, C. Angew. Chem. 1986, 98, 472-473

5. Minge, O.; Nugai, S.; Schmidbaur, H.; Z. Naturforsch., B: Chem. Sci., 2004, 59, 153-160

6. Soeldner, M.; Sandor, M.; Schier, A.; Schmidbaur, H.; Chem. Ber./Recueil. 1997, 130, 1671-1676

7. Han, Y.-Y.; Wu, Z.-J.; Chen, W.-B.; Du, X.-L.; Zhang, X.-M.; Yuan, W.-C. Org. Lett. 2011, 13, 5064-5067

8. Liu, P.; Chen, Y.; Deng, J.; Tu, Y. Synthesis, 2001, 14, 2078-2080

9. Hirone, N.; Sanjiki, H.; Tanaka, R.; Hata, T.; Urabe, H. Angew. Chem. Int. Ed. 2010, 49, $7762-$ 7764

10. Fu, P.-F.; Brard, L.; Li, Y.; Marks, T.J. J. Am. Chem. Soc. 1995, 117, 7157-7168 

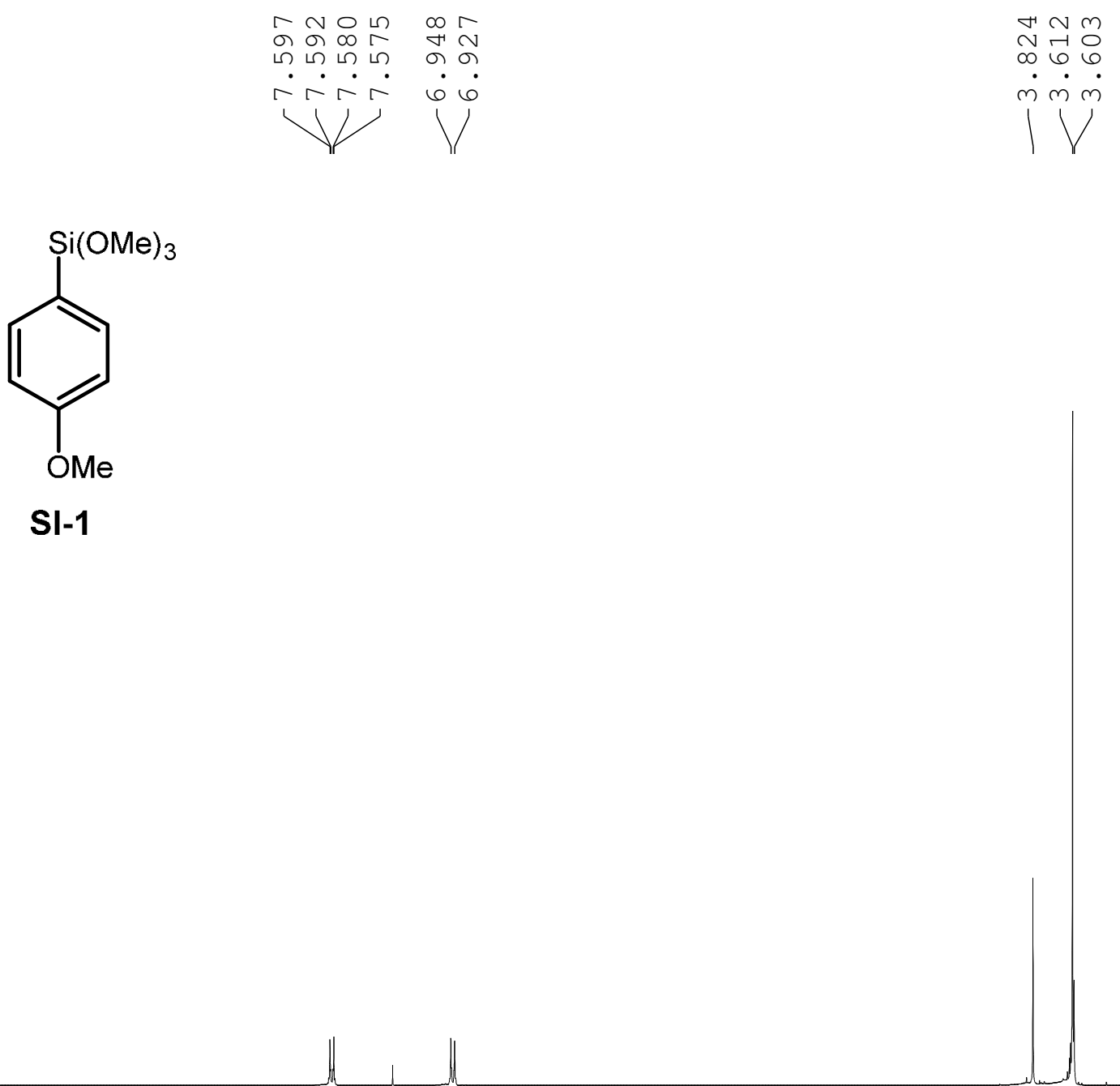

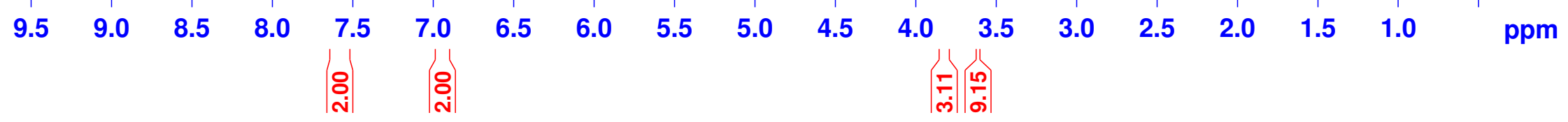




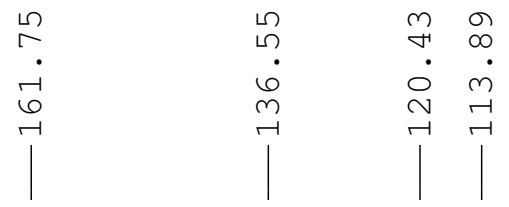

ำ

เก

|<smiles>COc1ccc([Si]OC(C)=O)cc1</smiles> 

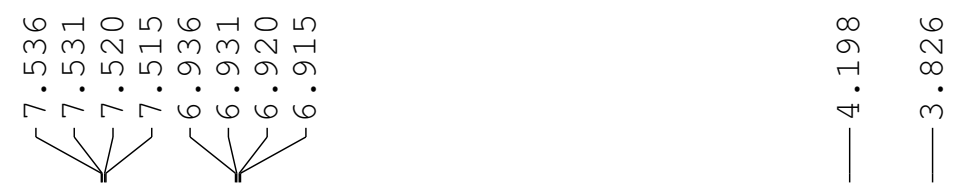<smiles>COc1ccc([SiH3])cc1</smiles>

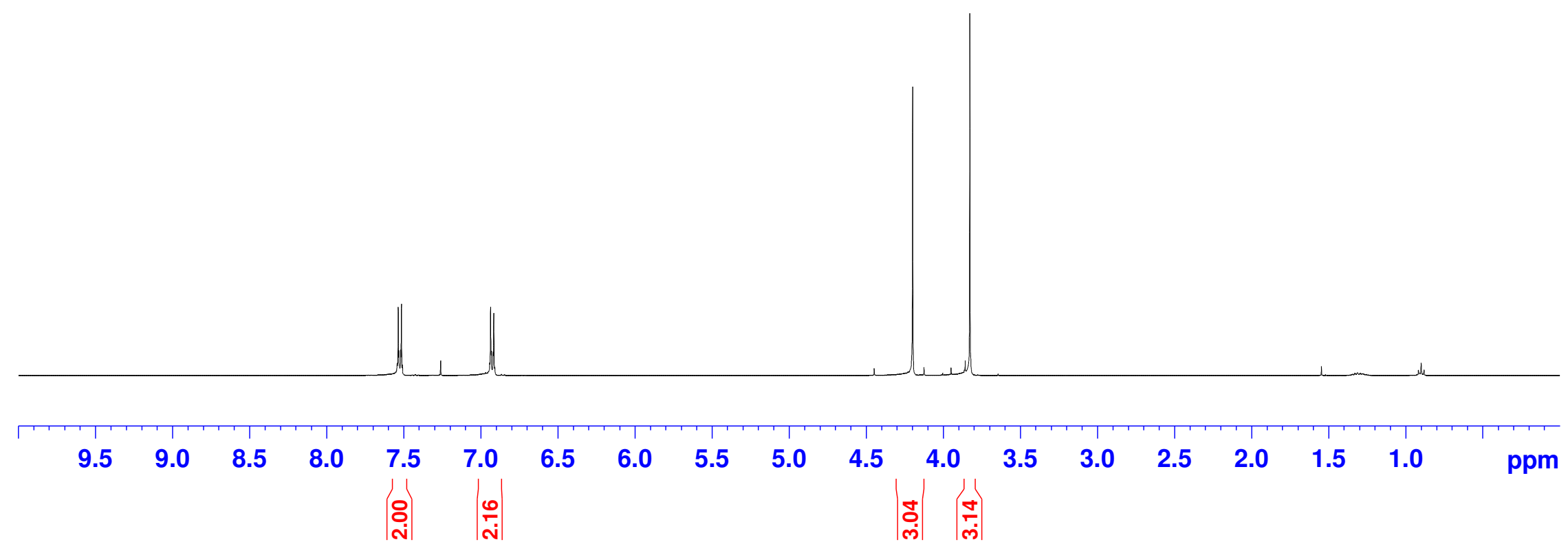




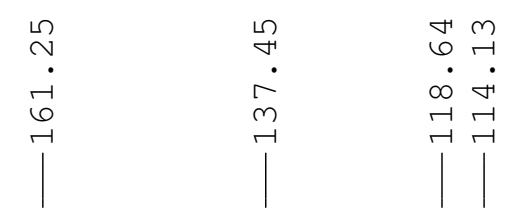

$$
\begin{aligned}
& 5 \\
& 0 \\
& 10 \\
& 1 \\
& 1
\end{aligned}
$$<smiles>COc1ccc(S)cc1</smiles>

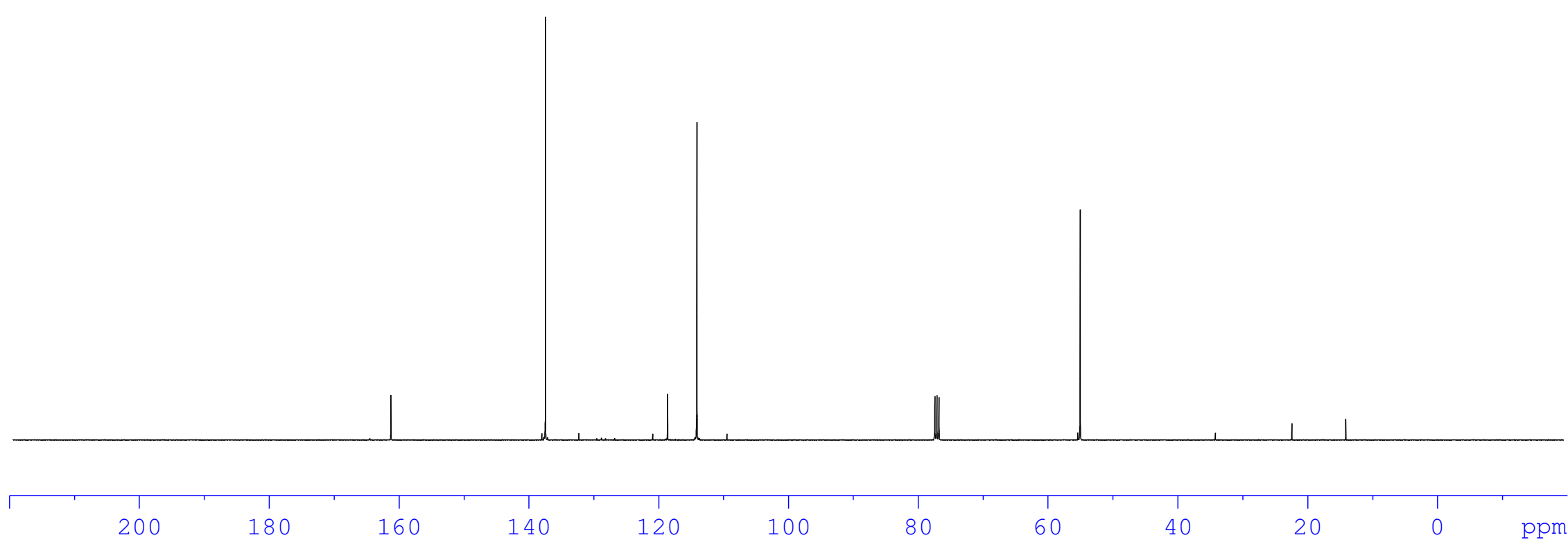




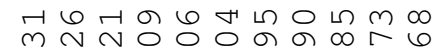

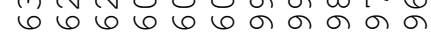

$\therefore \dot{\sim} \therefore \dot{\sim} \dot{\sim} \dot{\theta} \dot{0}$

$\longrightarrow$
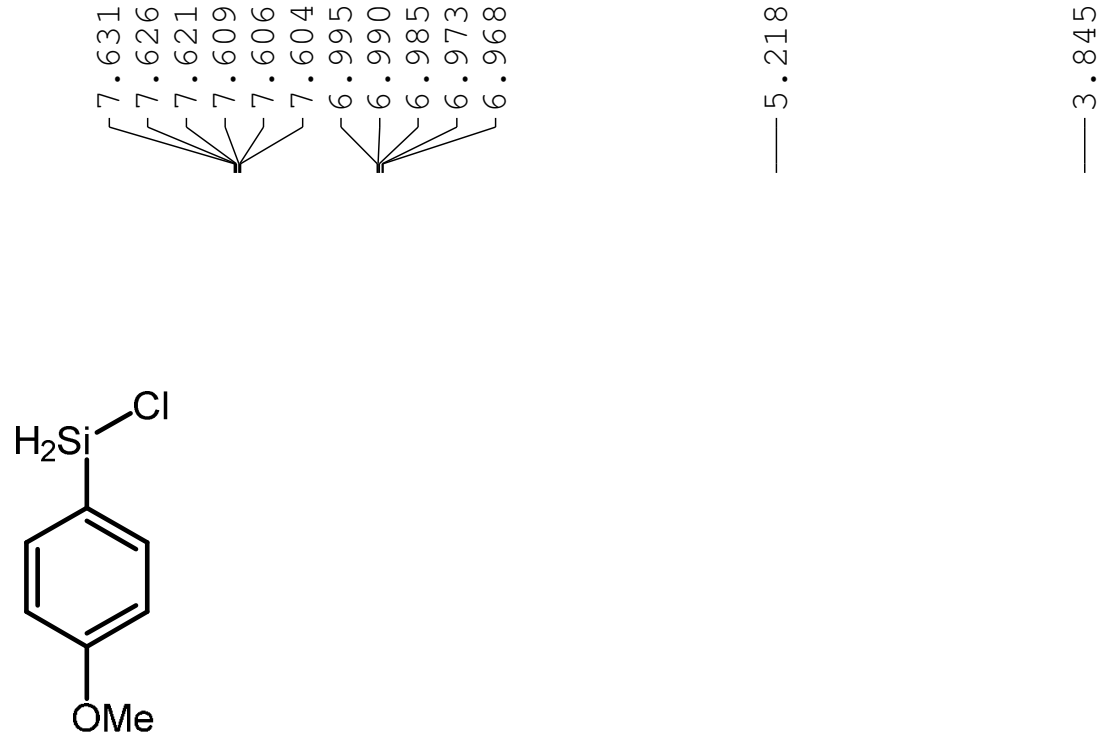

SI-3
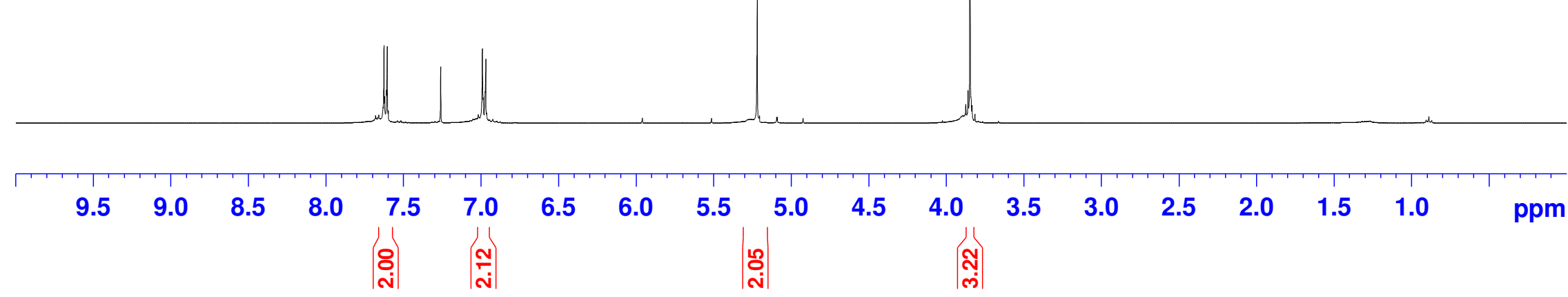


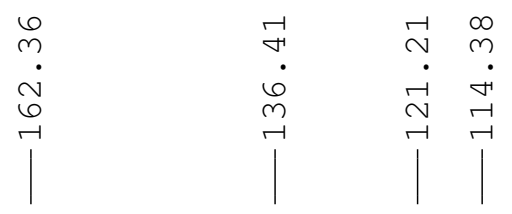

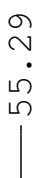
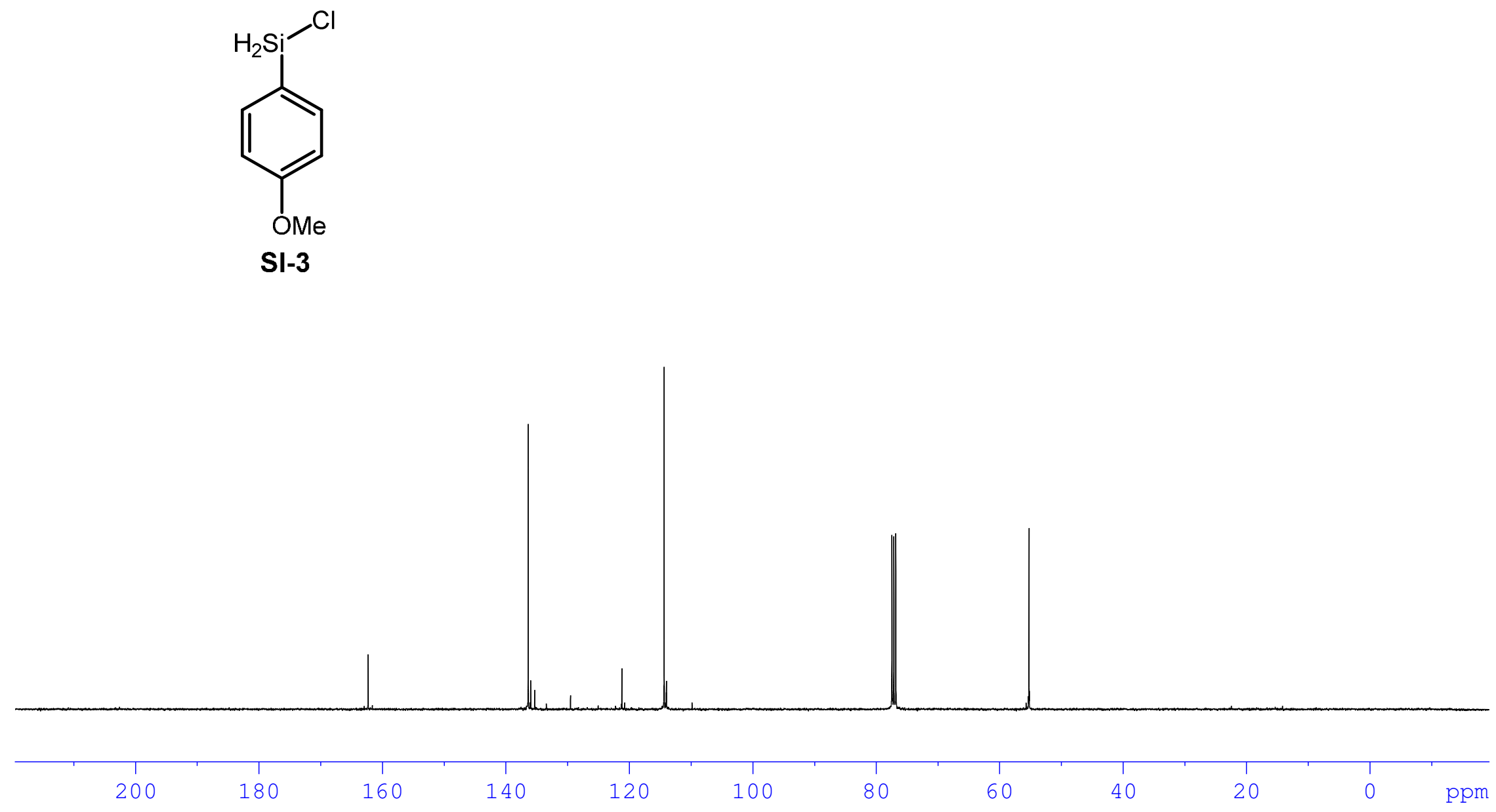

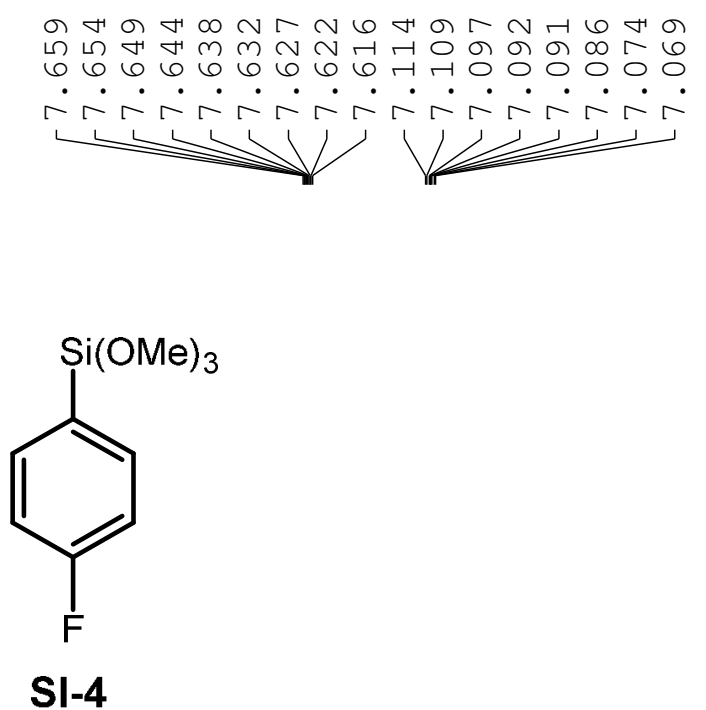

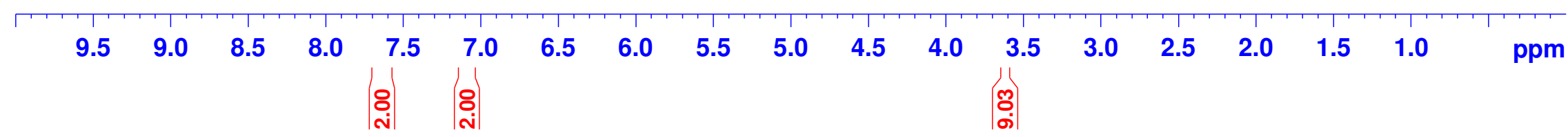



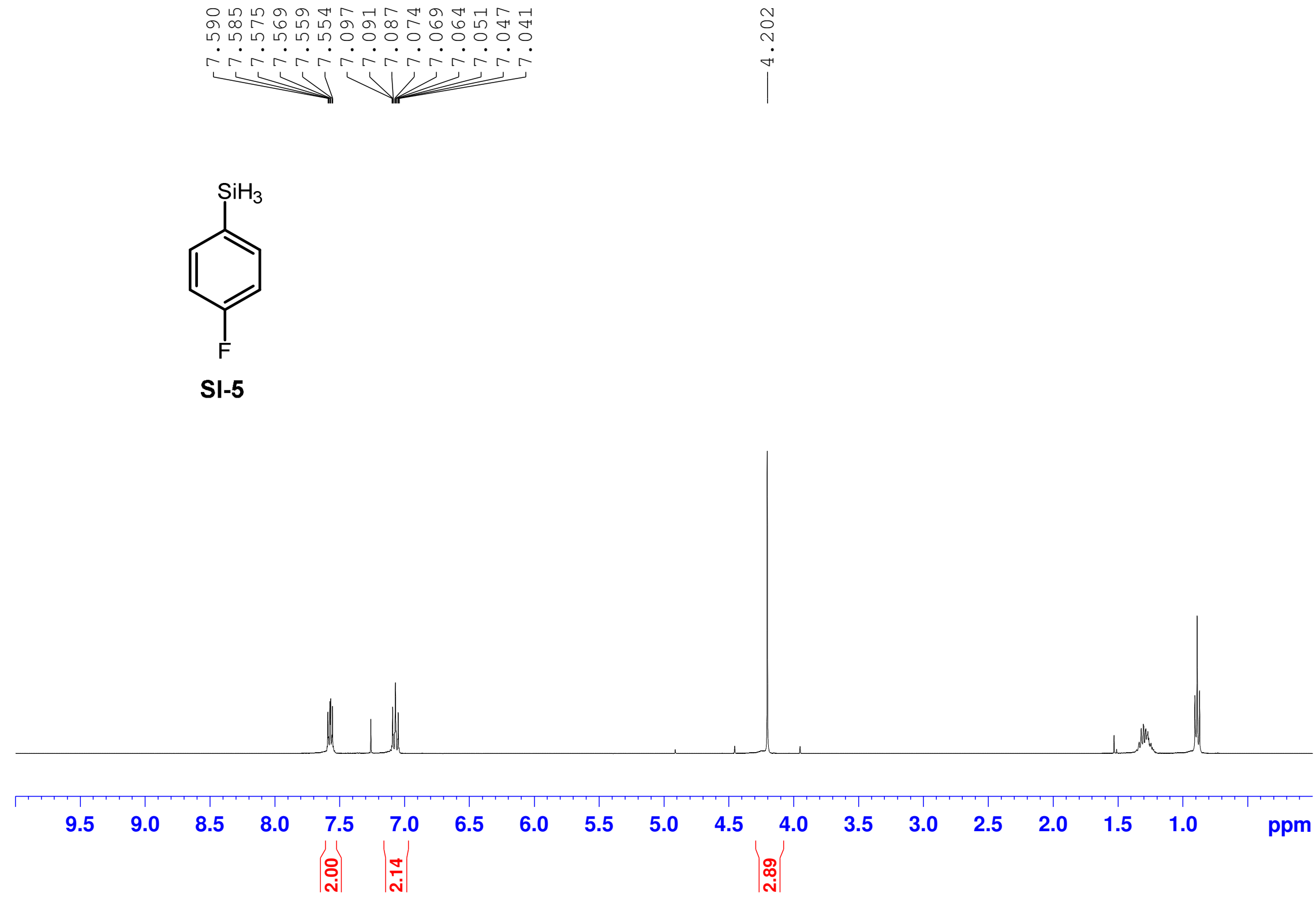
の

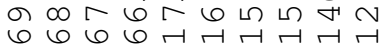

$r$
0
0
0

$\longrightarrow$

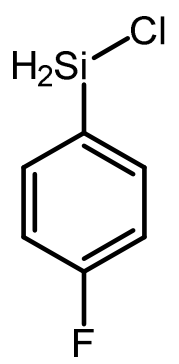

SI-6

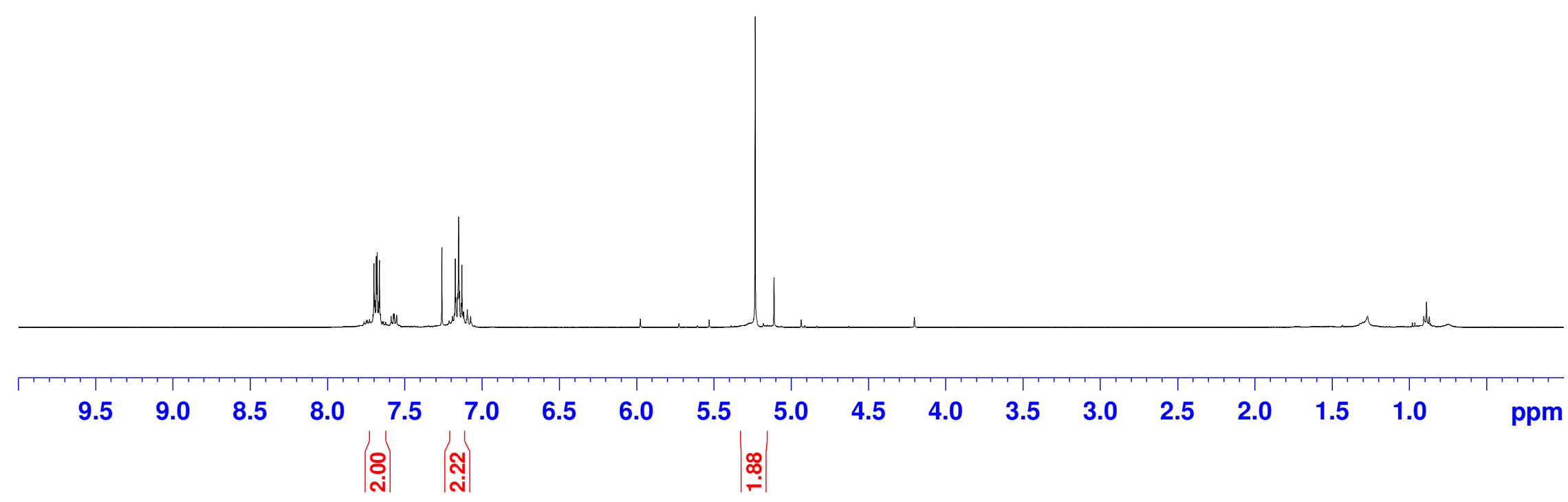



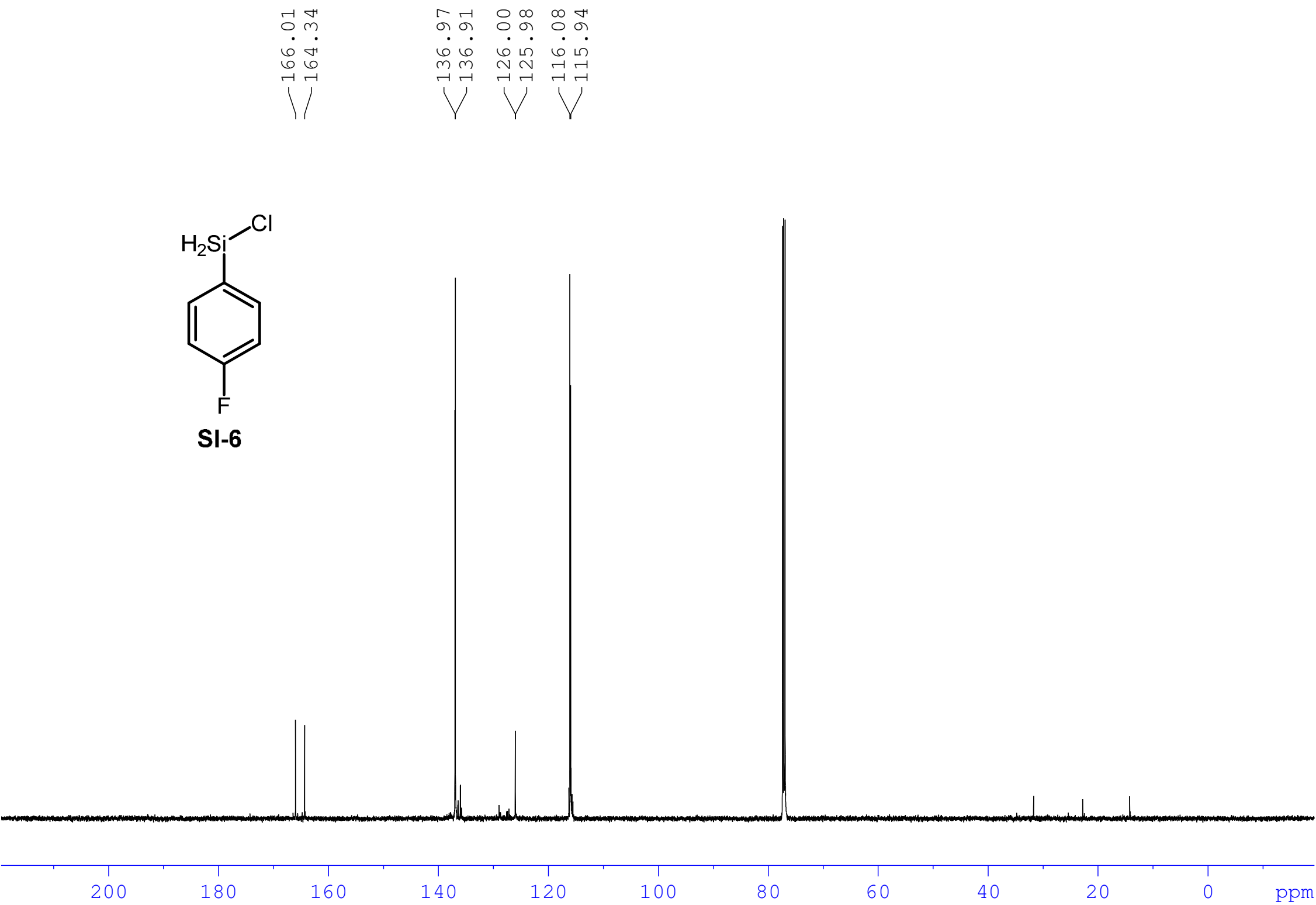


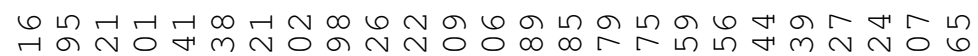
구의

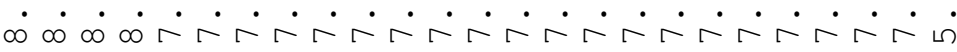
r<smiles></smiles>

\section{5} 8.58 8.07

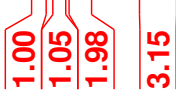
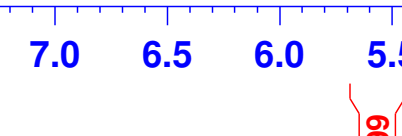

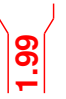




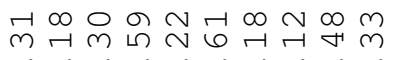

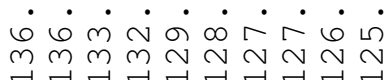

$\underbrace{2}$

$\rightarrow 1$
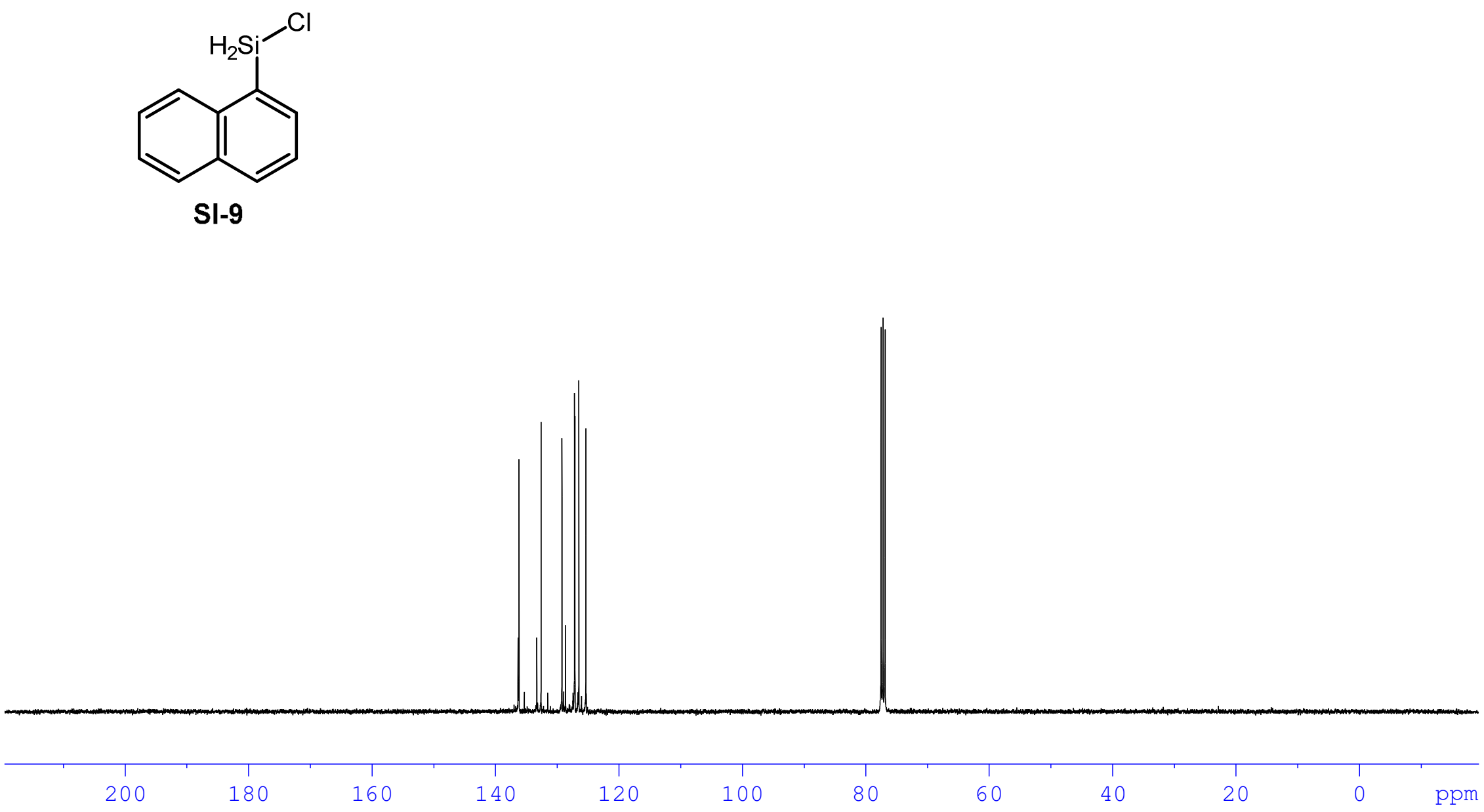


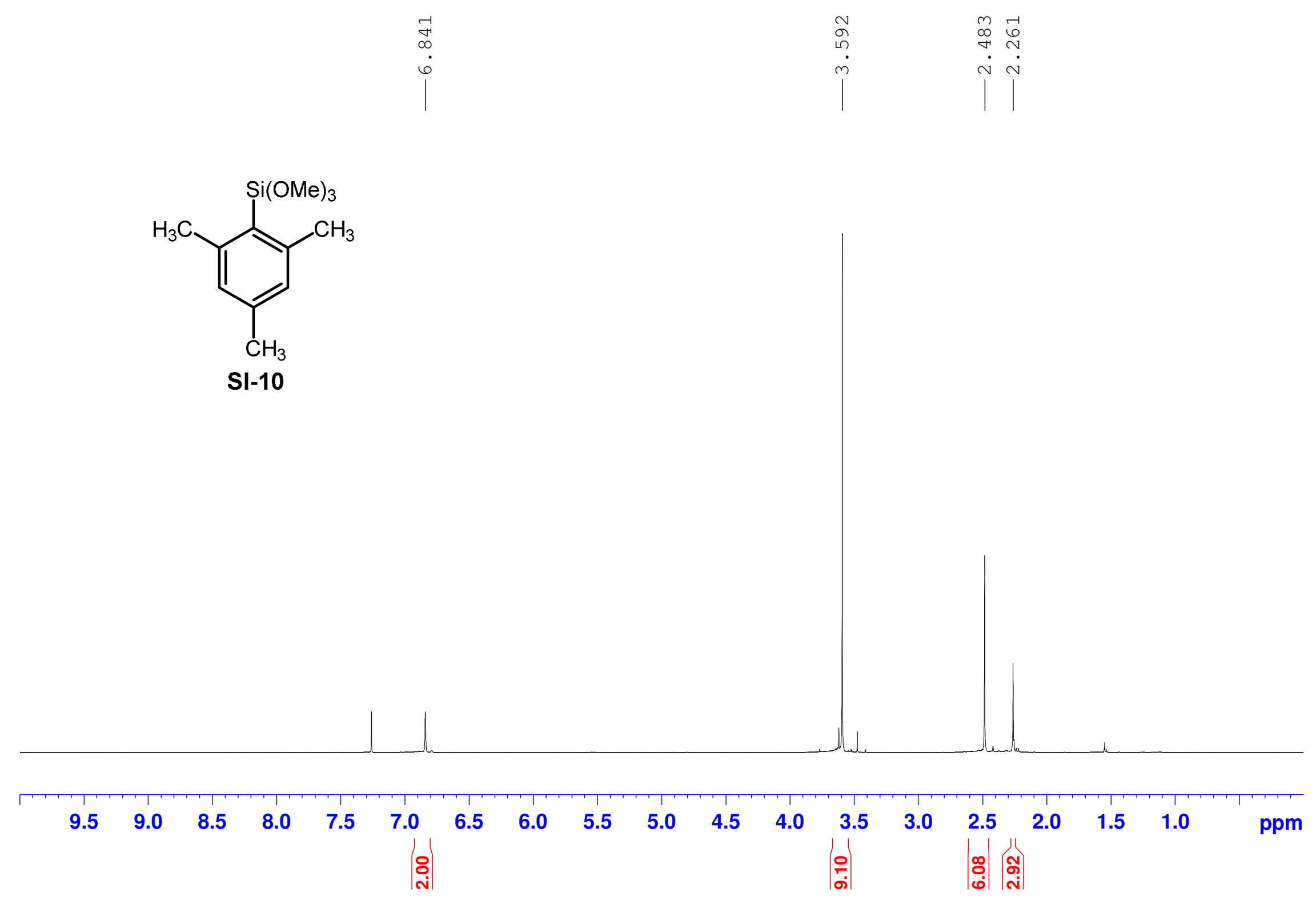



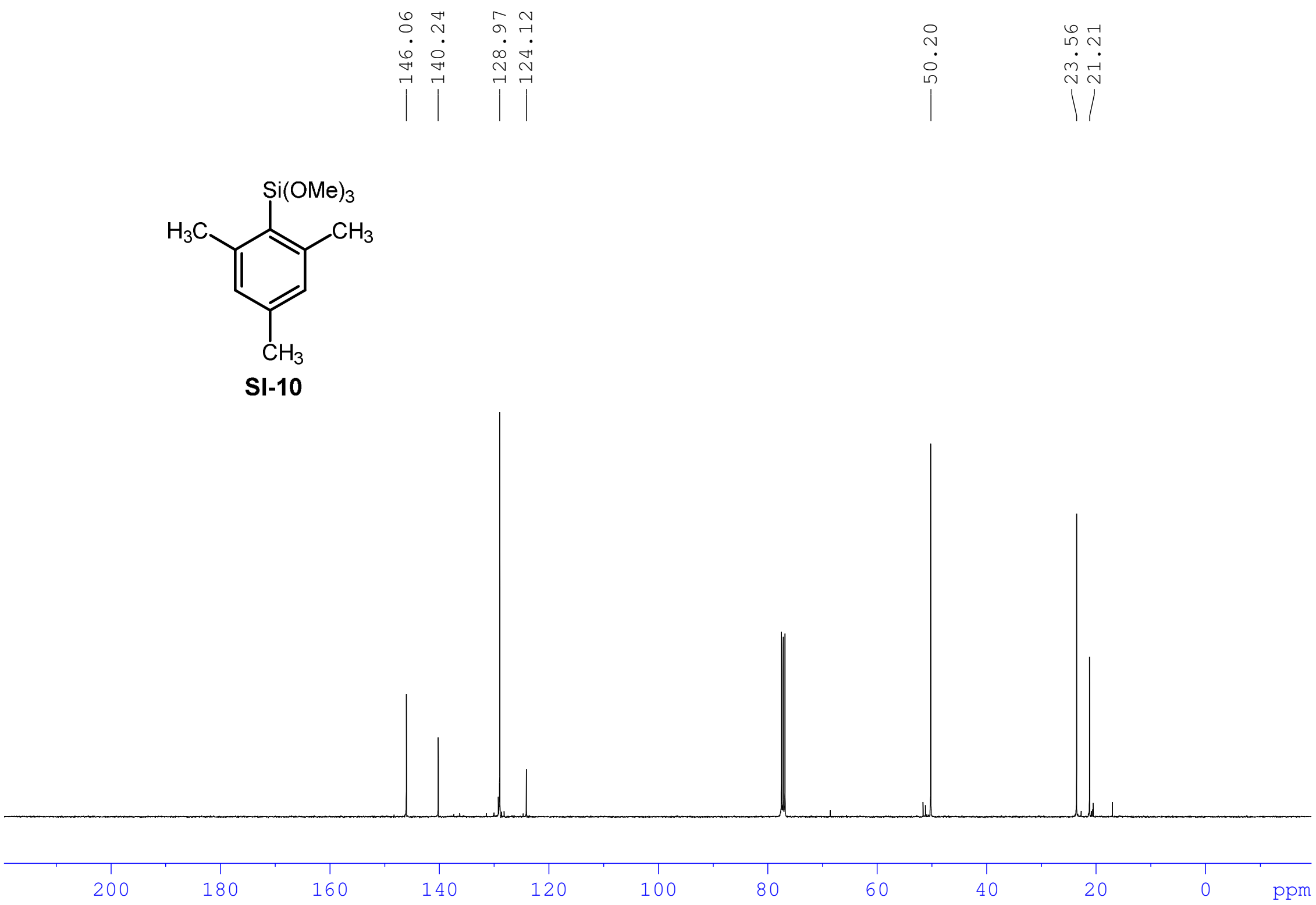


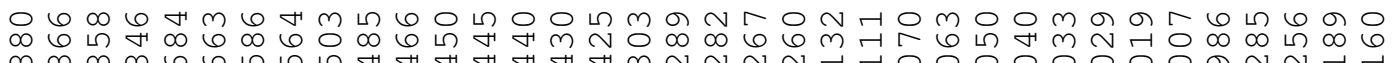

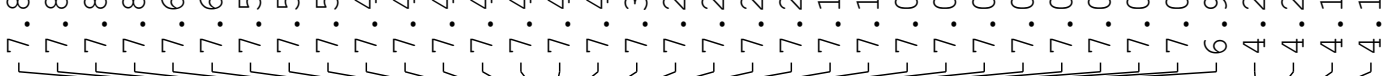

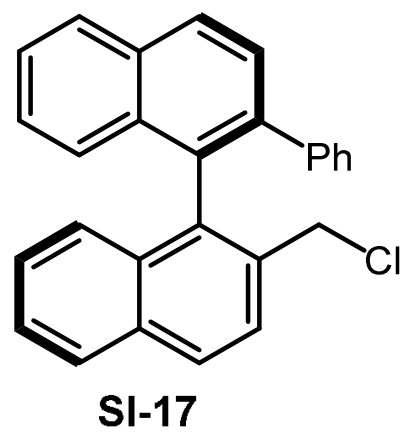

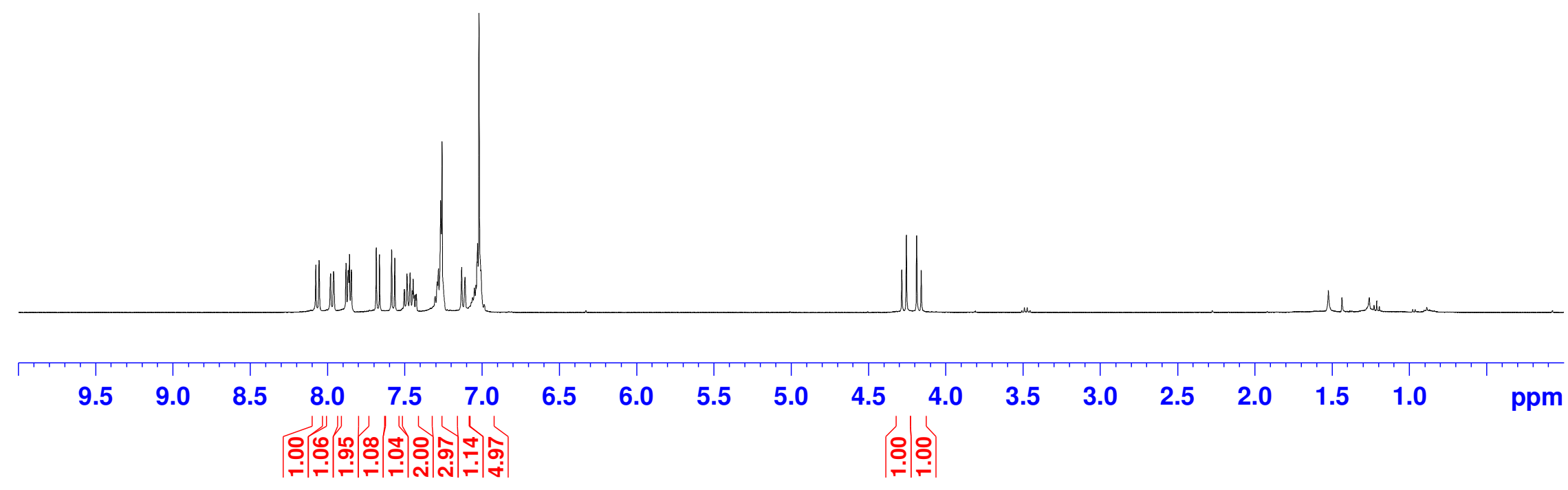




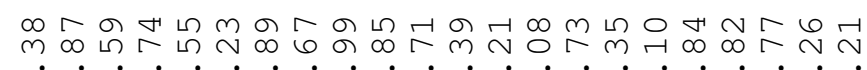

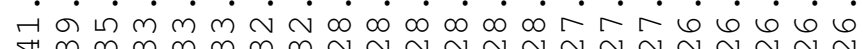

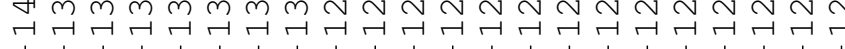
$\longrightarrow$
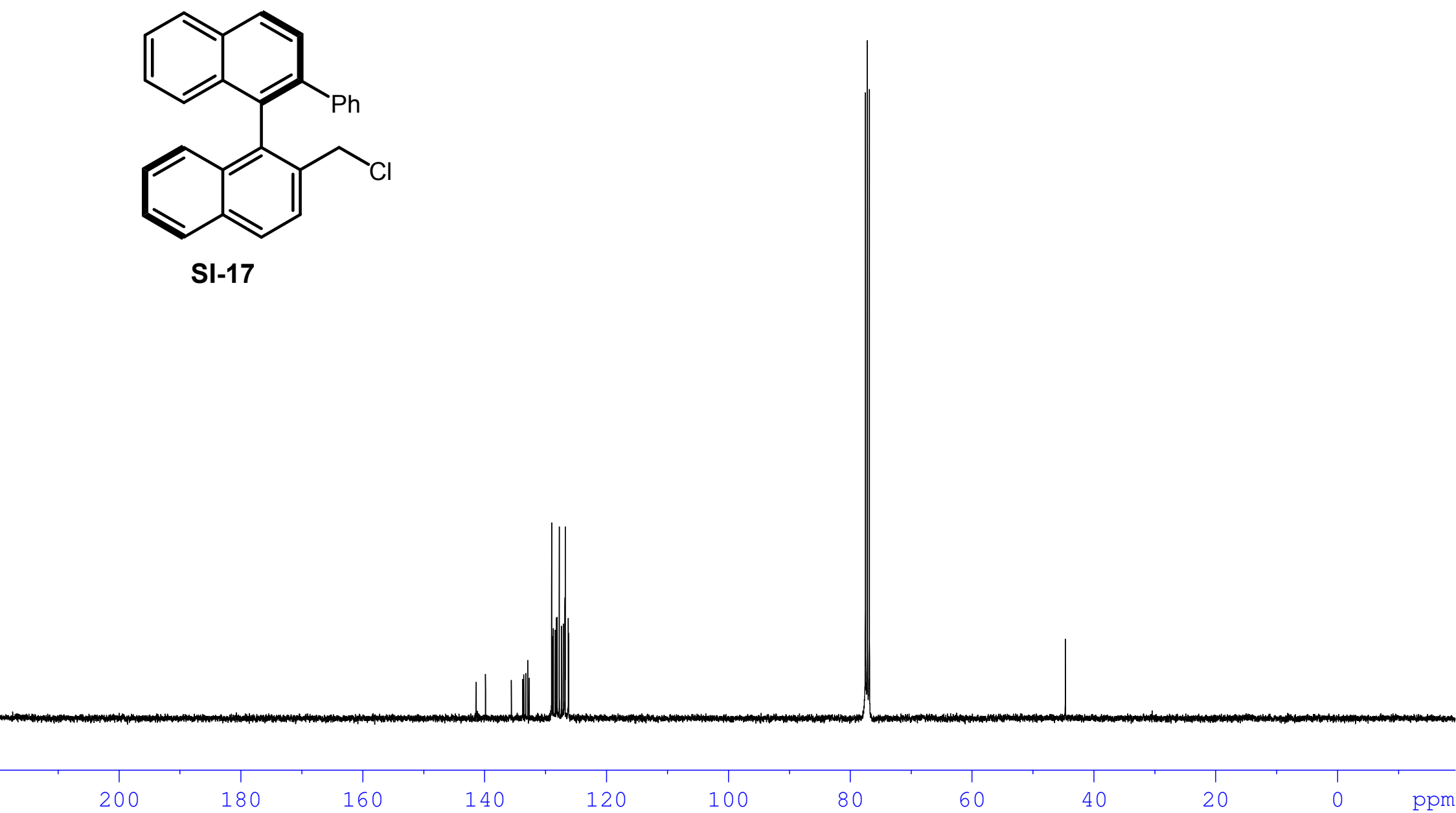
எ 虫

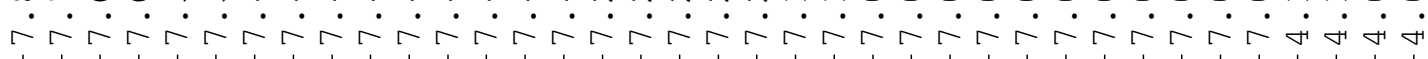
$\longrightarrow$<smiles></smiles>

SI-18
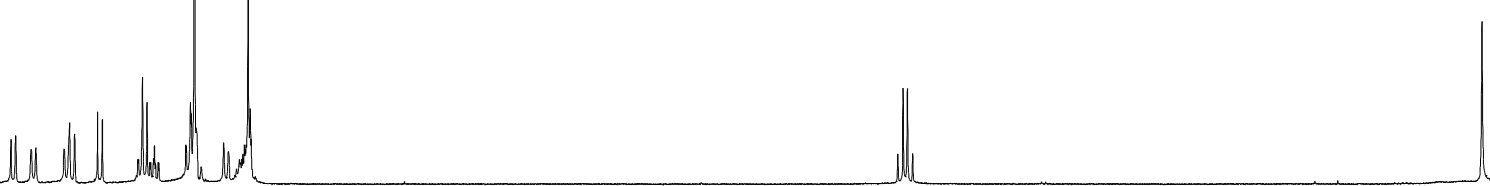

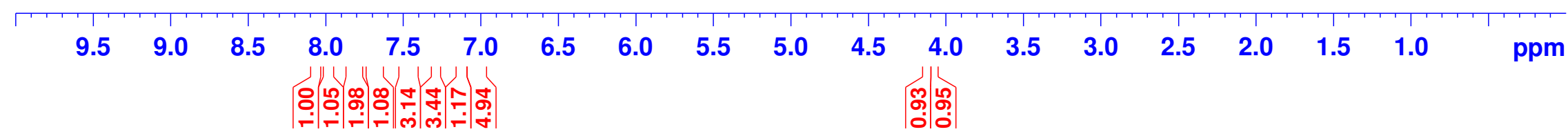




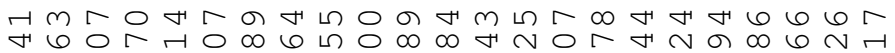

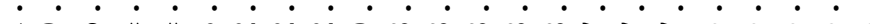
H

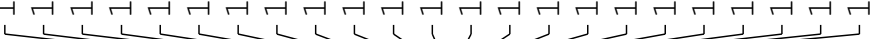<smiles>ICc1ccc2ccccc2c1-c1c(-c2ccccc2)ccc2ccccc12</smiles>

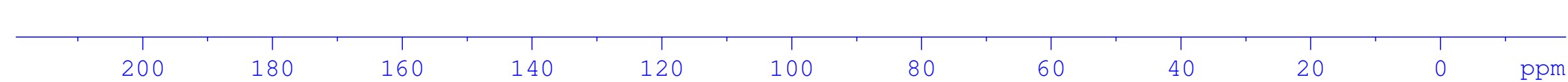




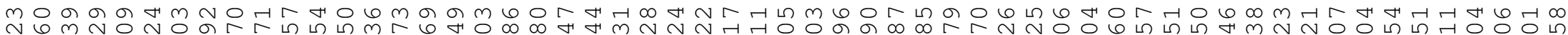

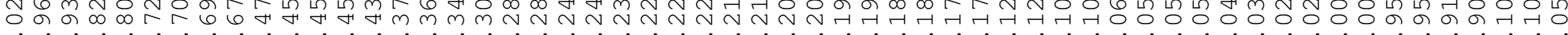

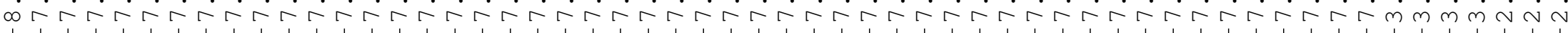<smiles>c1ccc([SiH2]Cc2ccc3ccccc3c2-c2c(-c3ccccc3)ccc3ccccc23)cc1</smiles> 


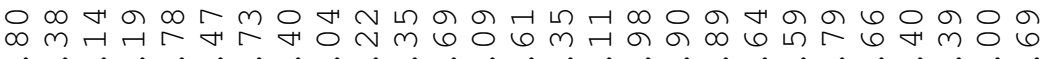

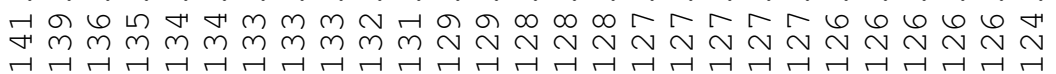

r L +
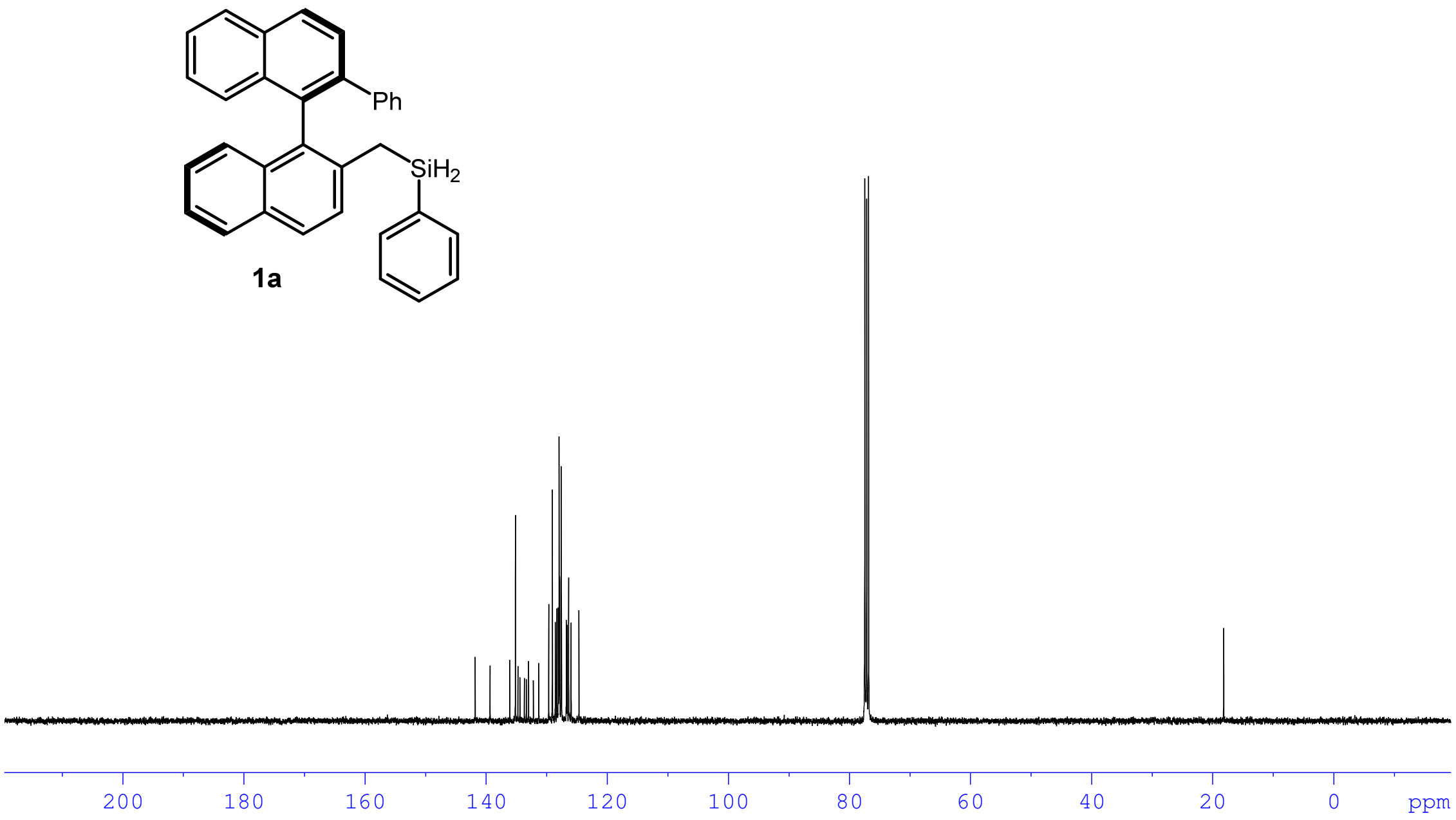


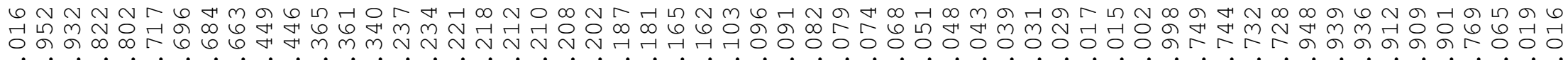

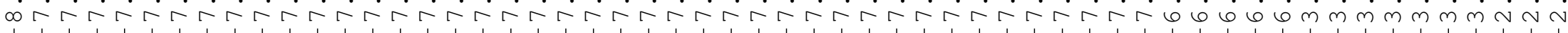

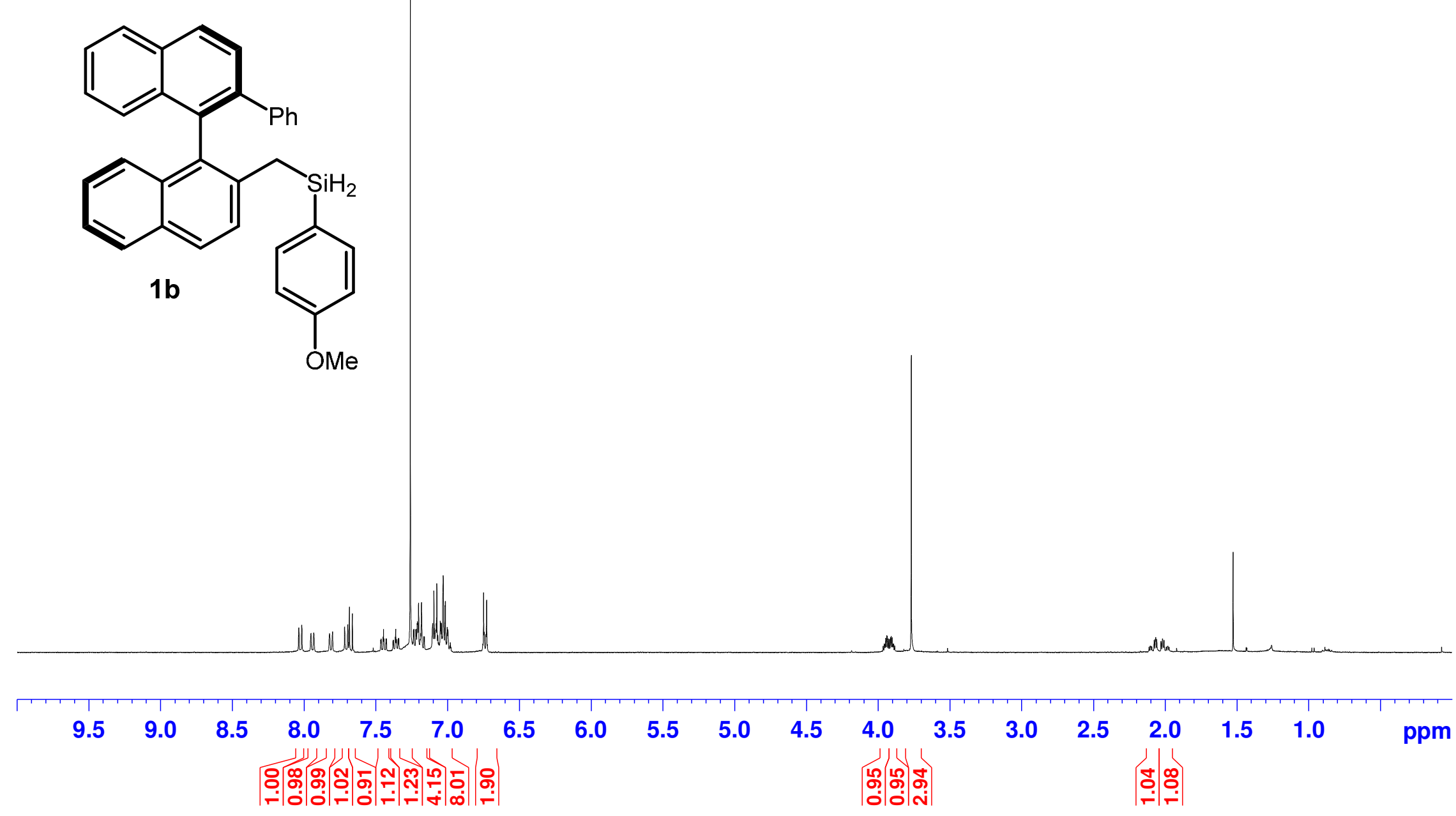




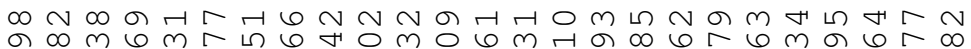

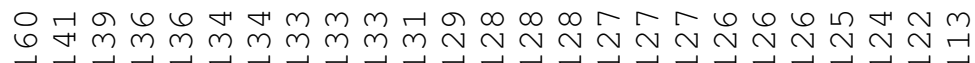

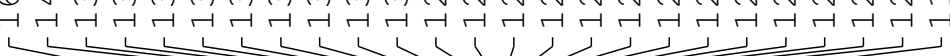

( )
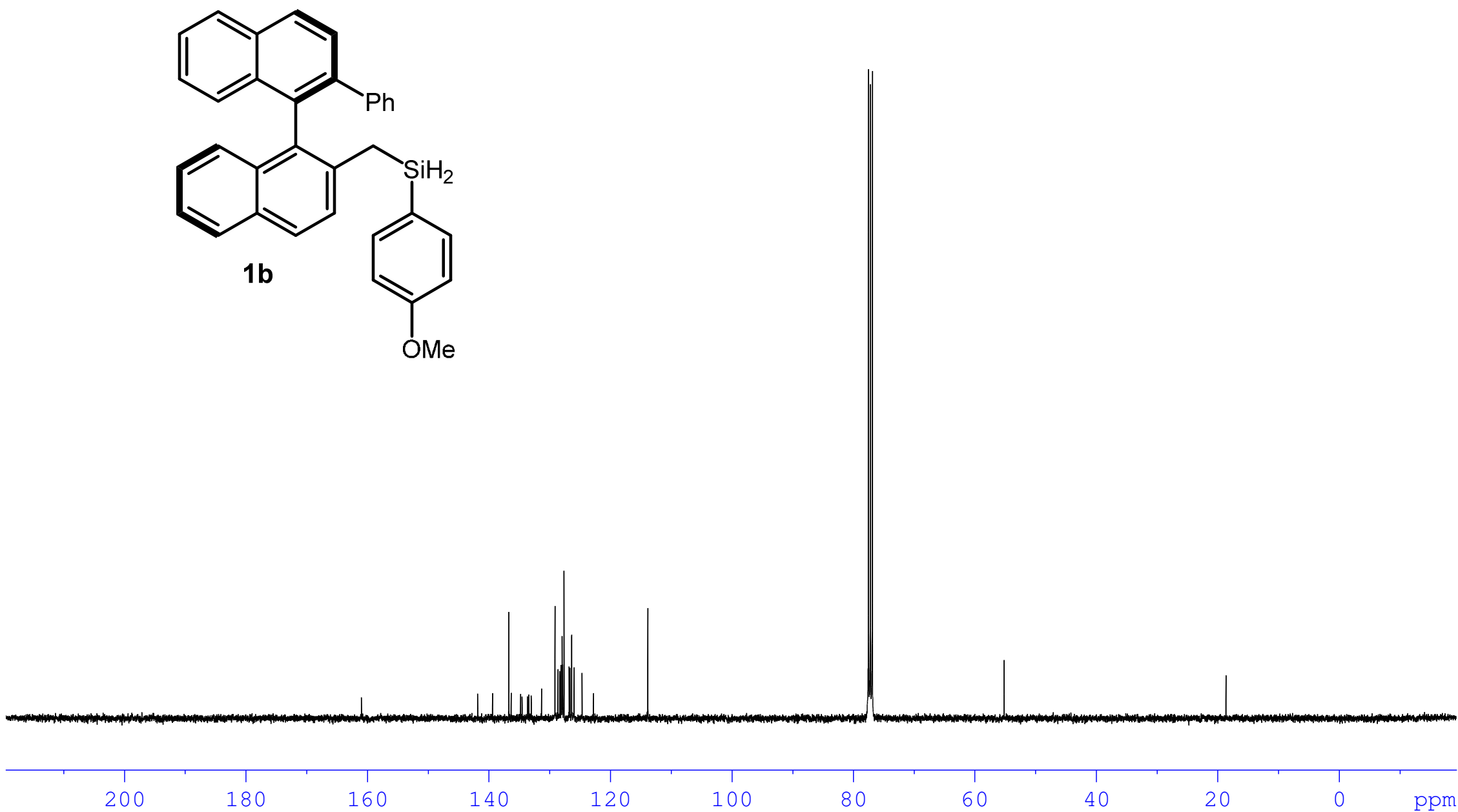
e) の

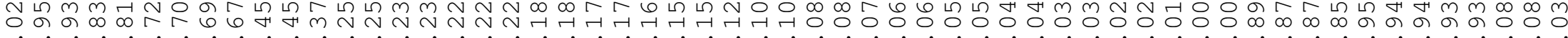

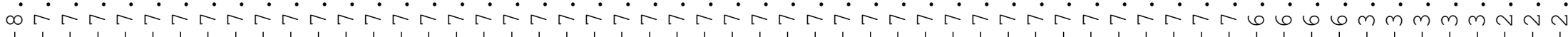

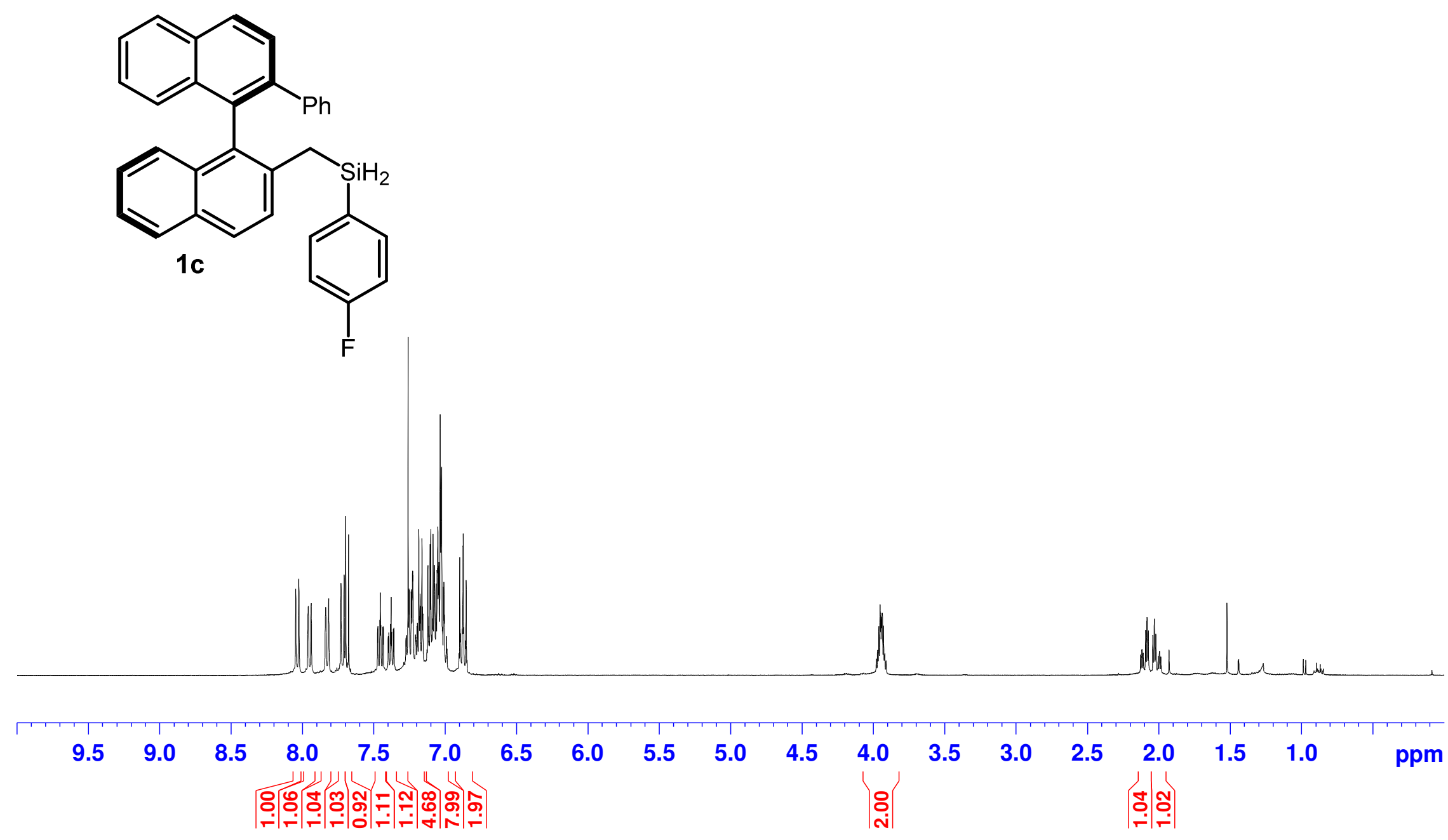


மூ

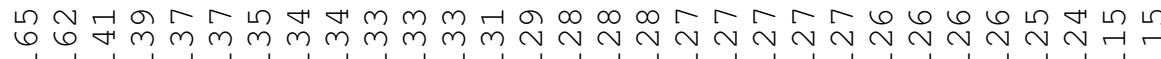

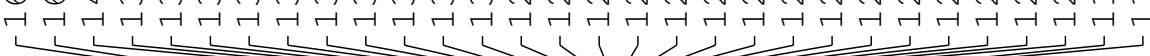

$\longrightarrow$<smiles>Fc1ccc([SiH2]Cc2ccc3ccccc3c2-c2c(-c3ccccc3)ccc3ccccc23)cc1</smiles>

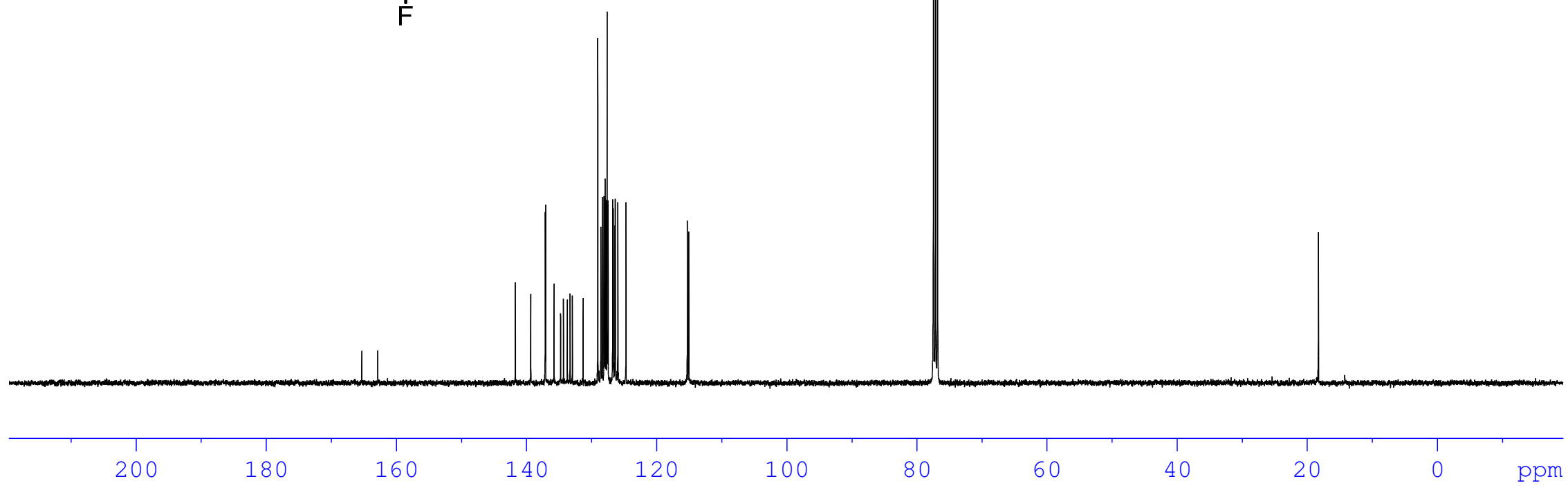




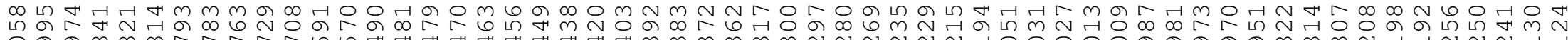

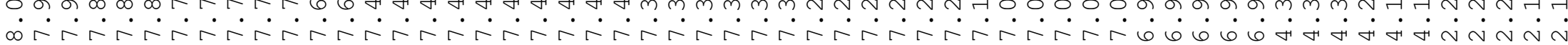

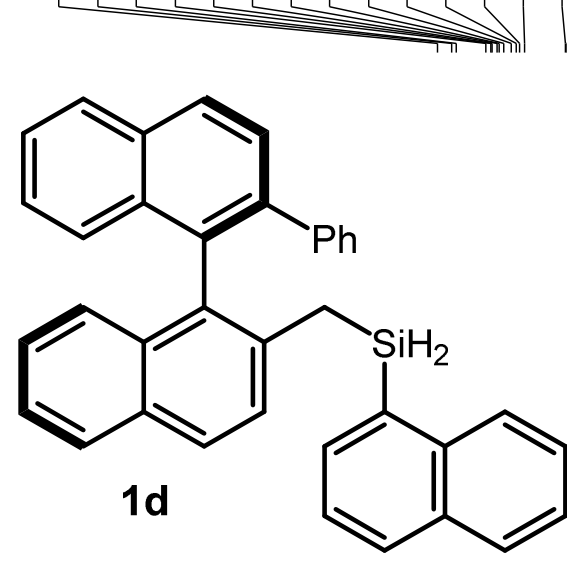

hIIIIIIII IIII

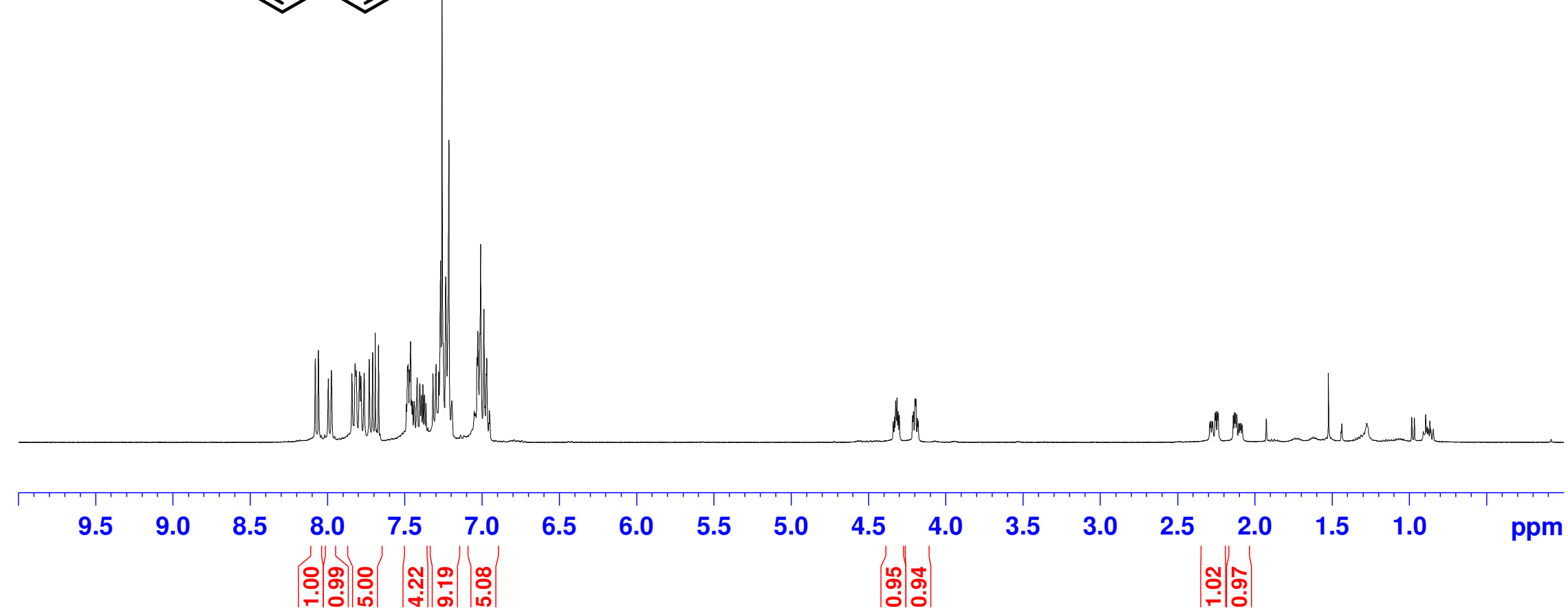




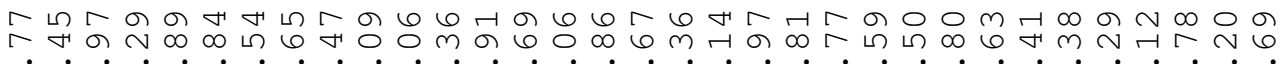

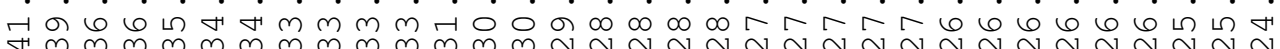

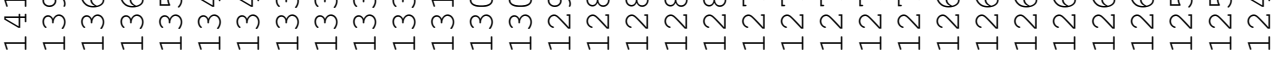

$\longrightarrow$
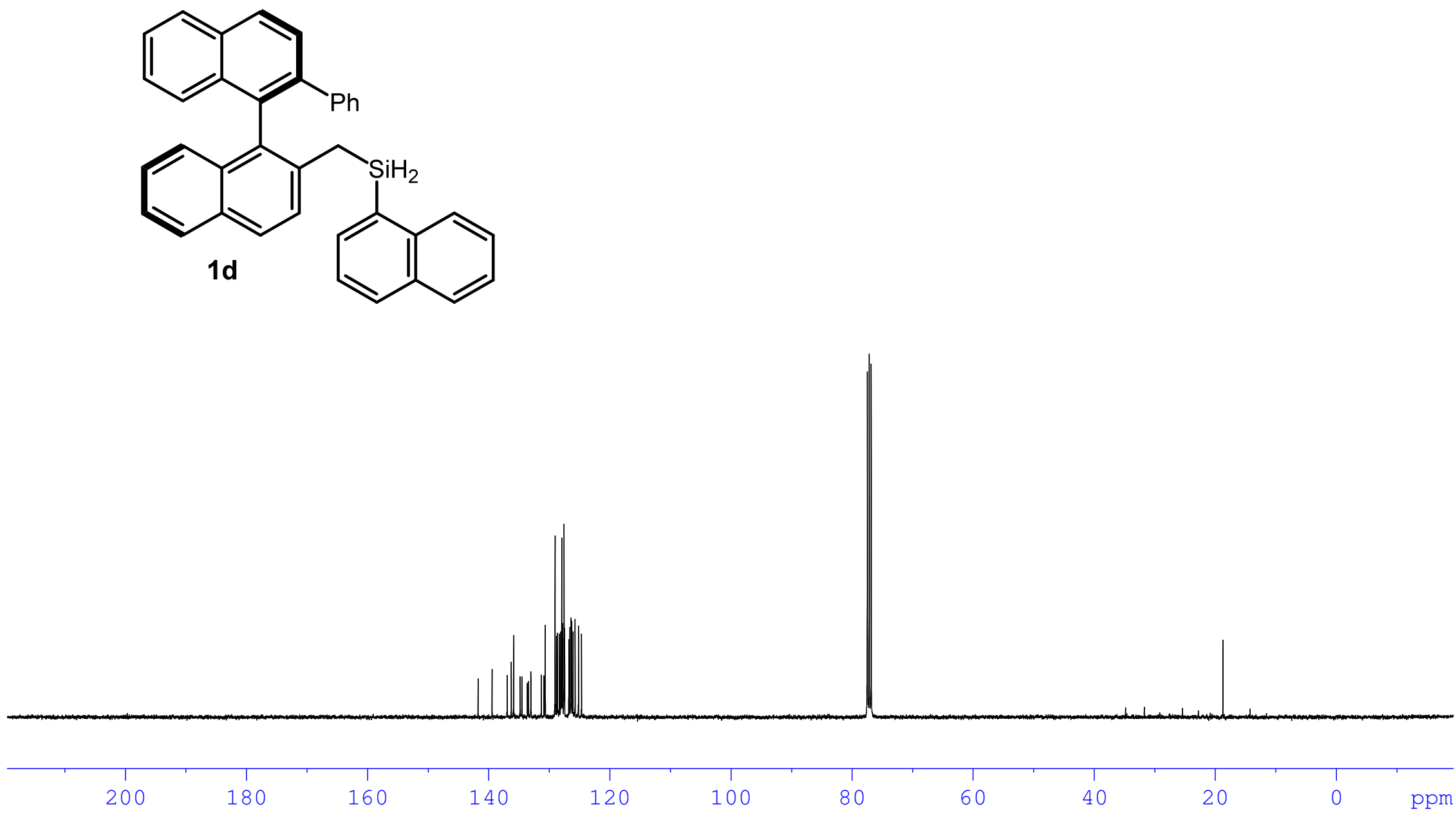


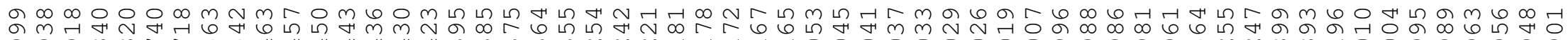

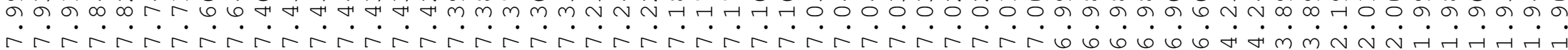
(II)

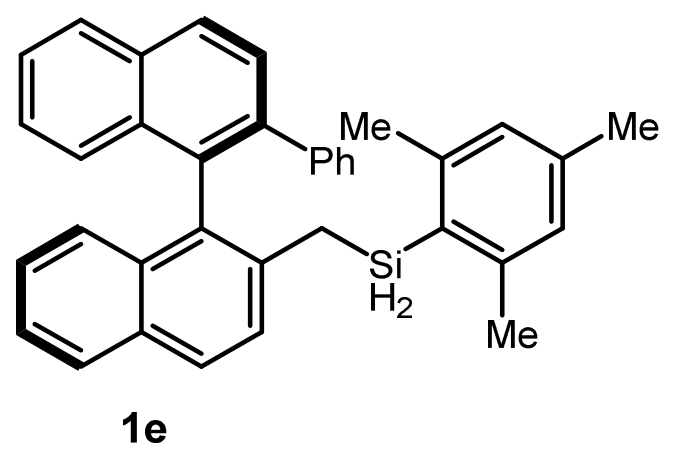

$1 e$
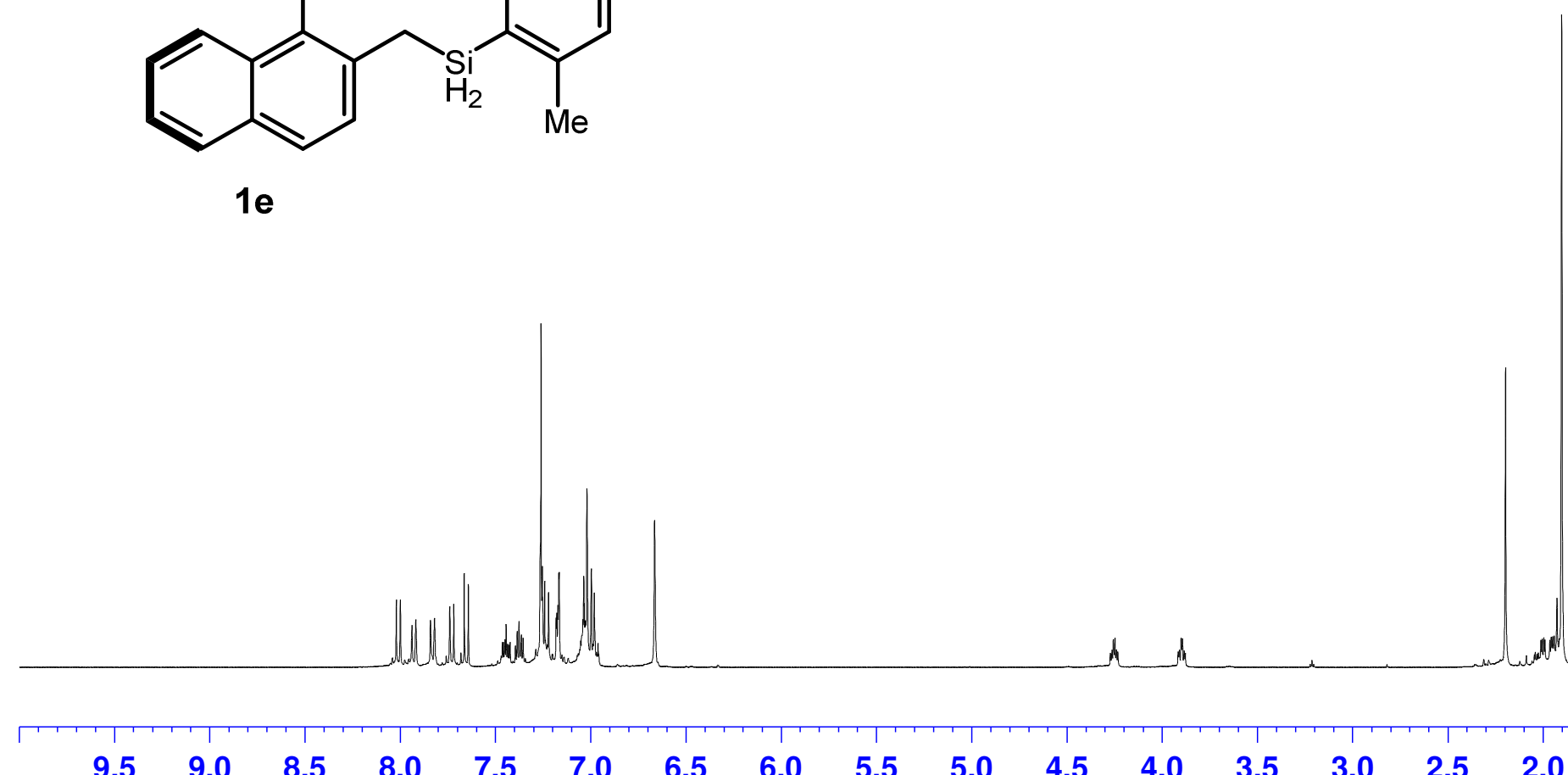

9.59
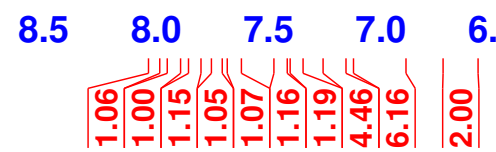

6.56

$5.5 \quad 5$

5.04

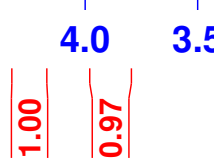

30

52

2.0

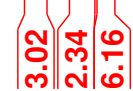




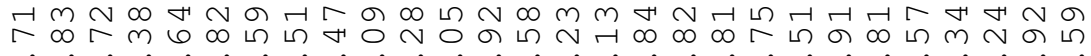

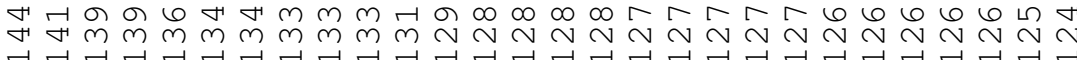

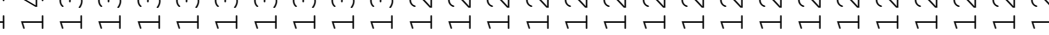

r

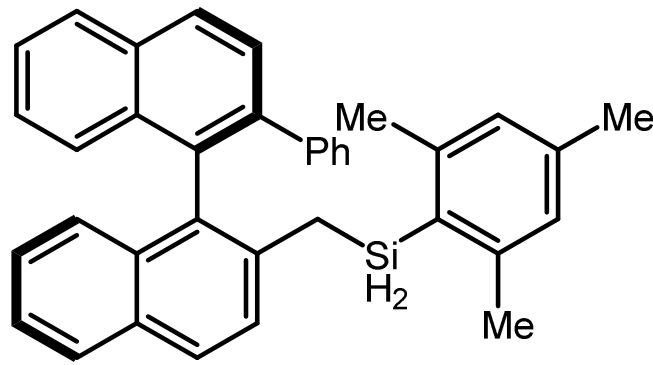

$1 e$

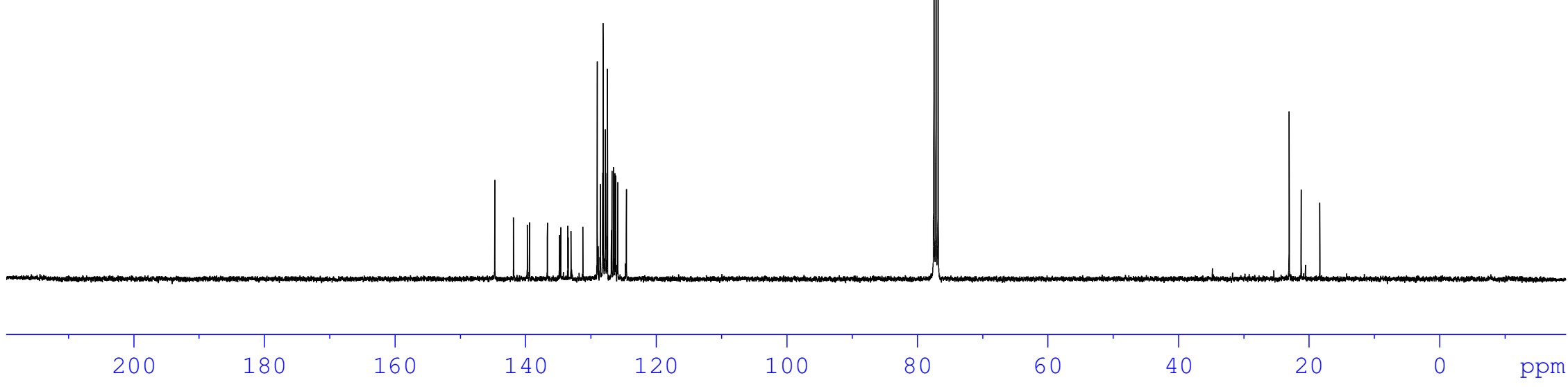


<smiles>c1ccc(C[SiH2]c2ccccc2)cc1</smiles>

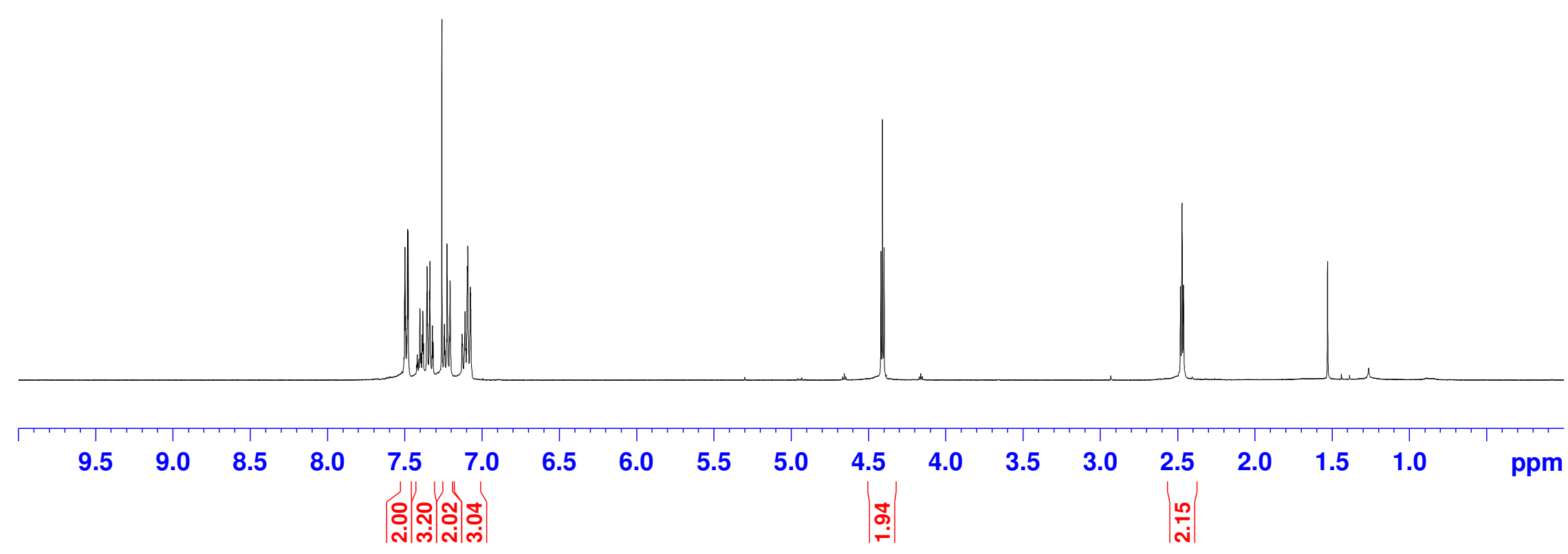



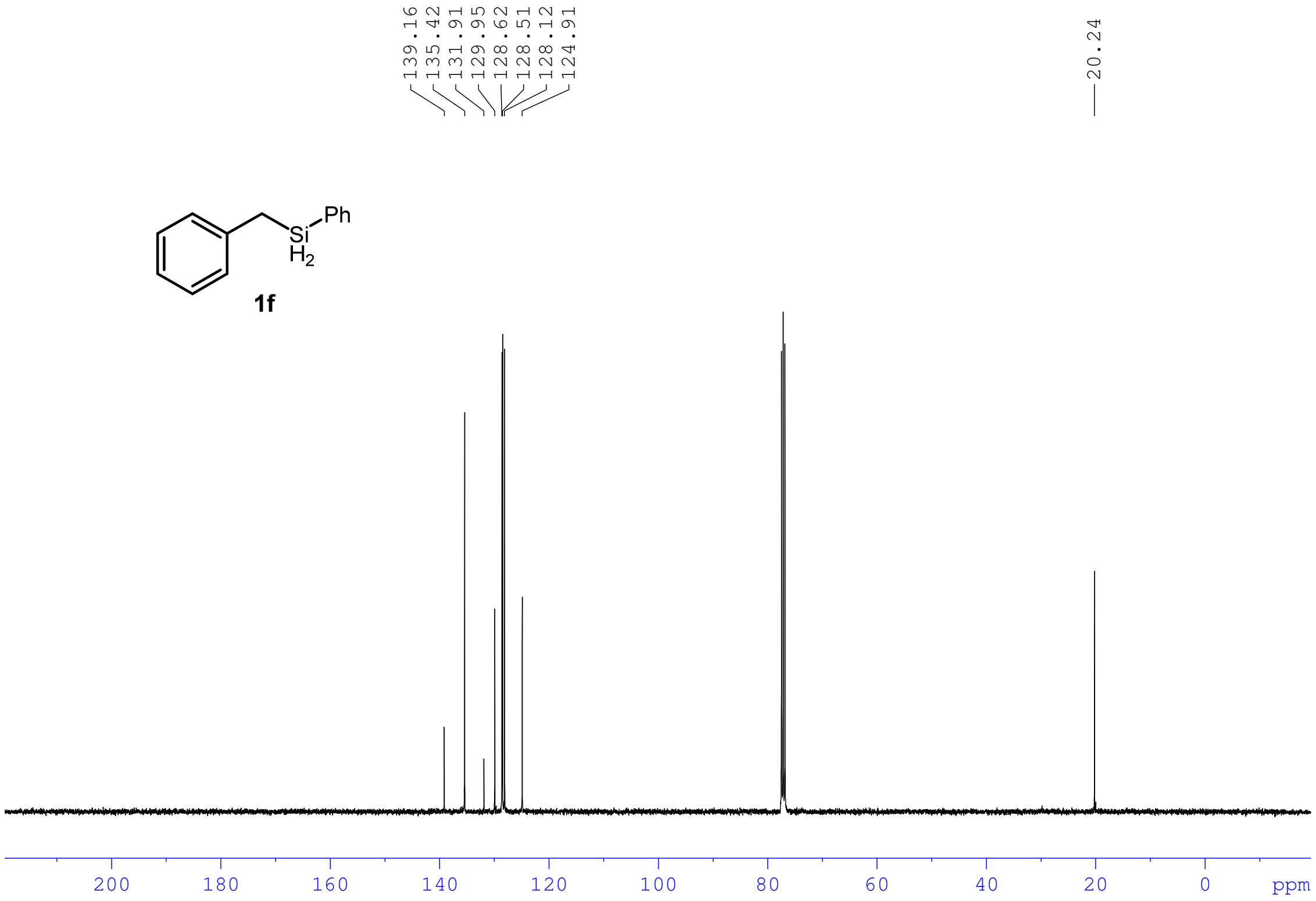
다의 ○००ठन न न ने ब न

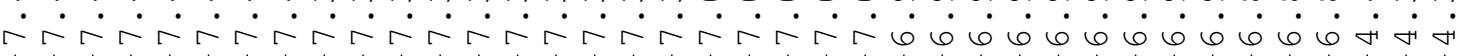
표 $N$ $\dot{\sim} \dot{\sim} \dot{\sim}$ mint

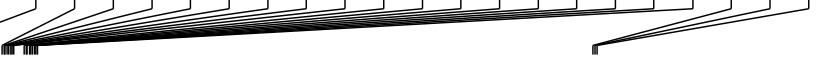<smiles>Fc1ccc(C[SiH2]c2ccccc2)cc1</smiles>

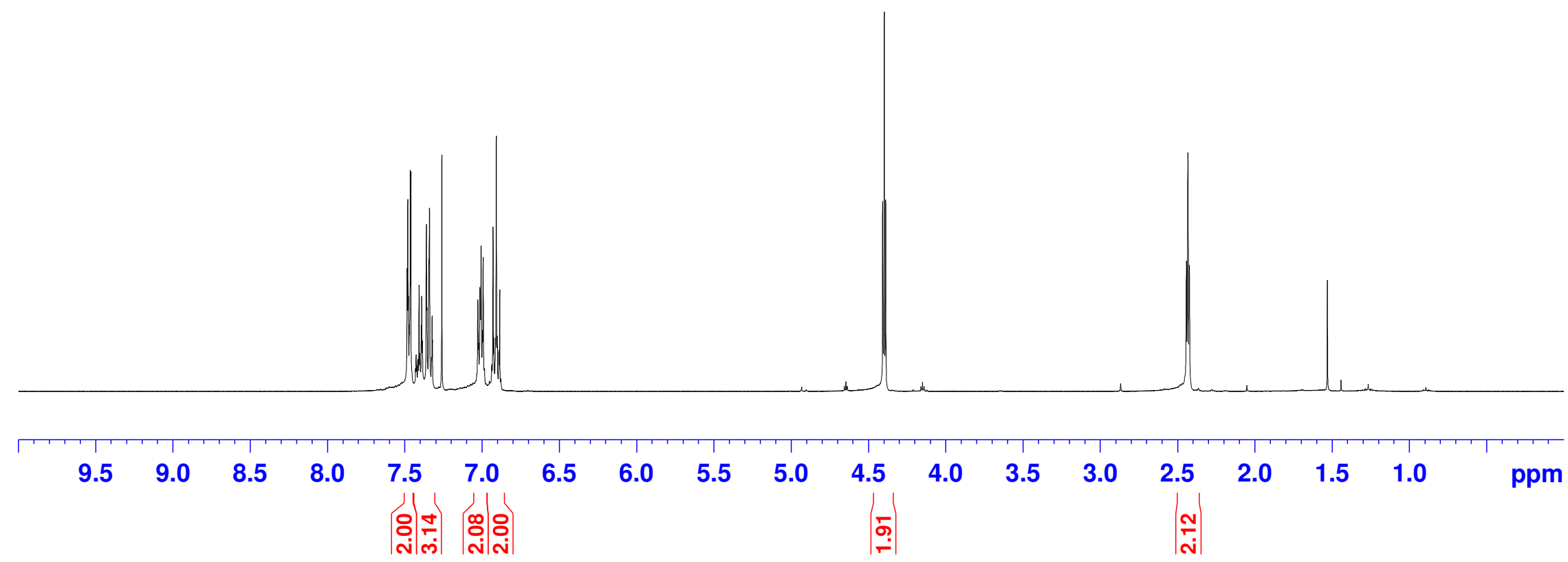




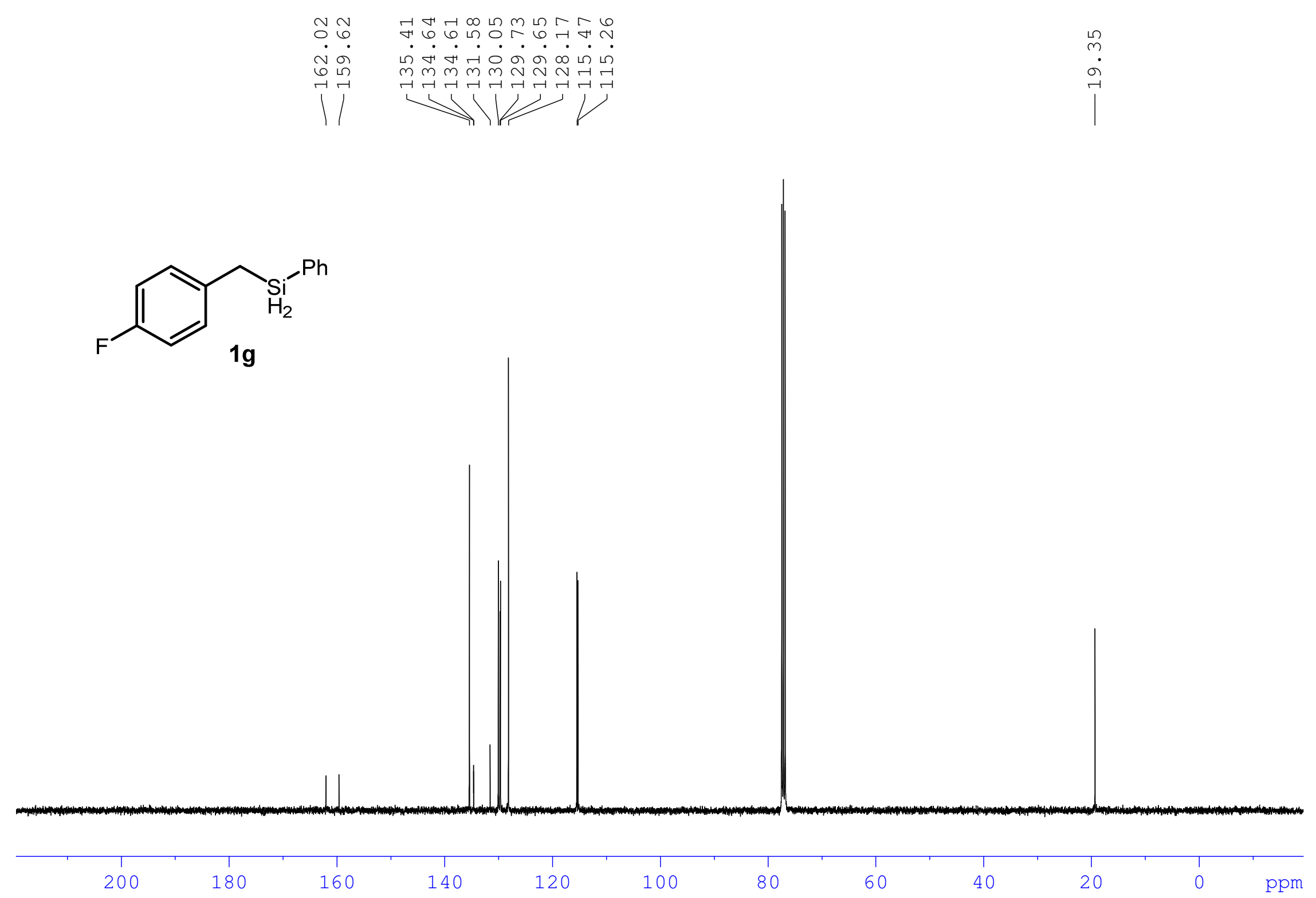




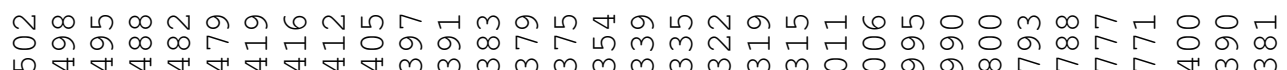

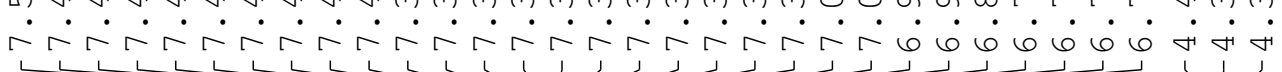

맘요

अंत

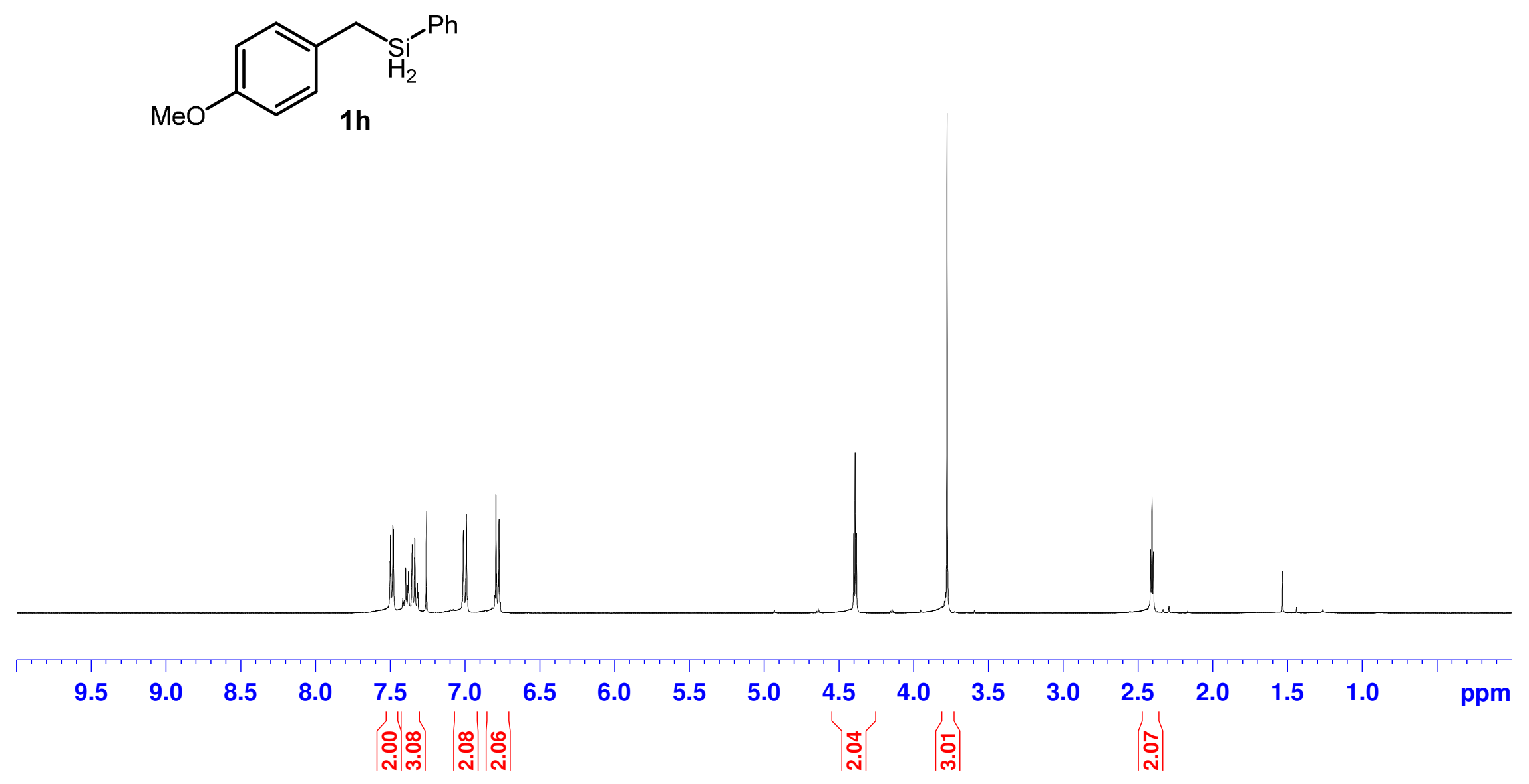



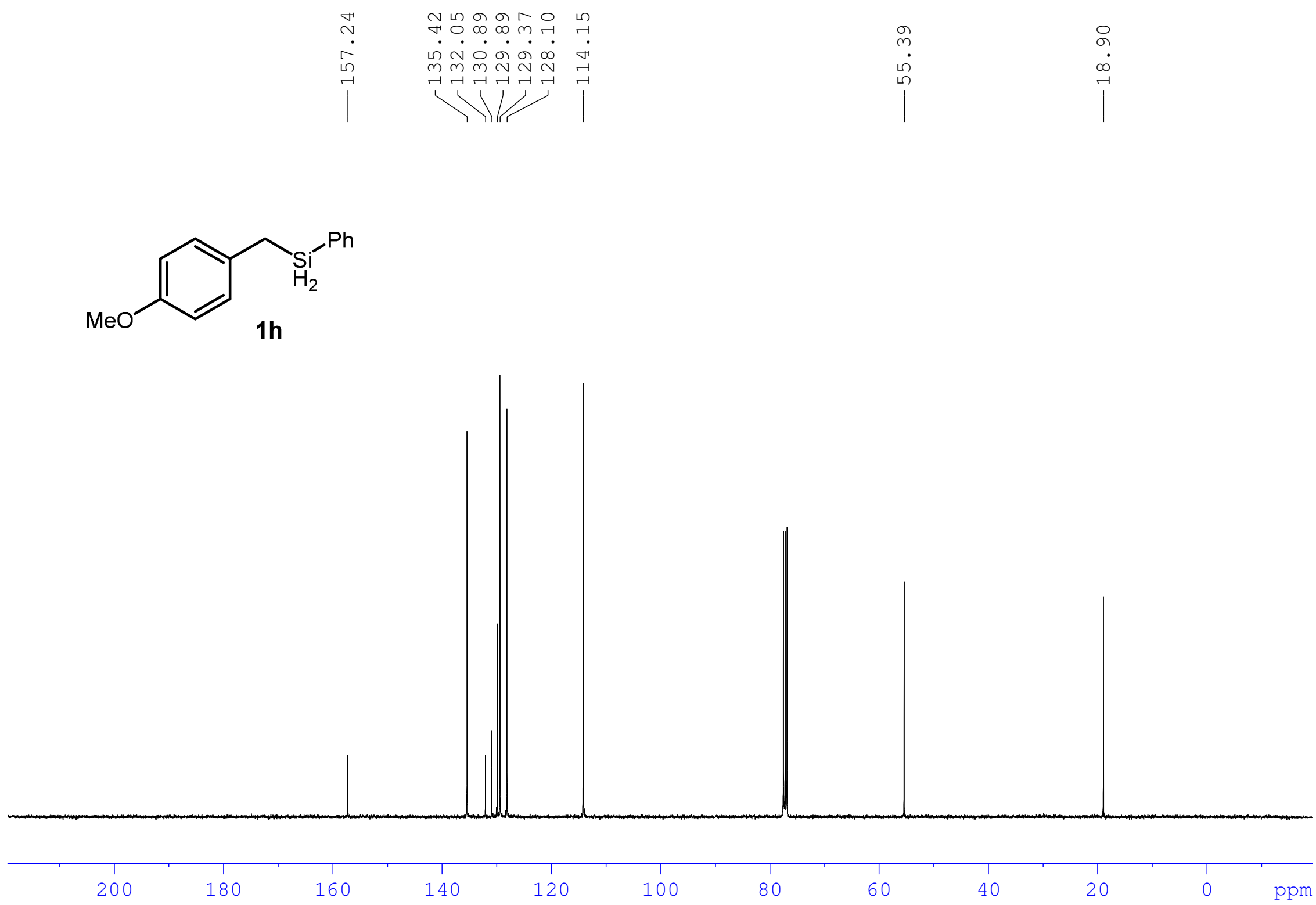


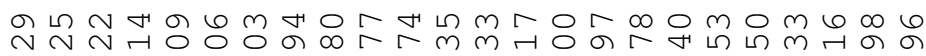

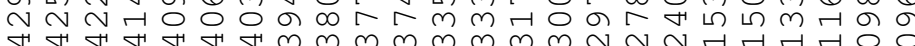

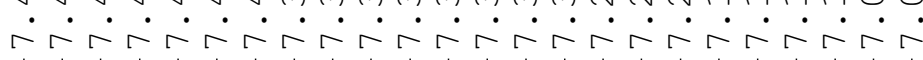

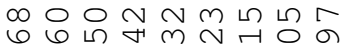
66666666 เ $\dot{\sim} \dot{\sim} \dot{\sim} \dot{\sim} \dot{\sim} \dot{\sim} \dot{\sim}$ $+1$

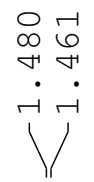<smiles>CC([HgH2]c1ccccc1)c1ccccc1</smiles>

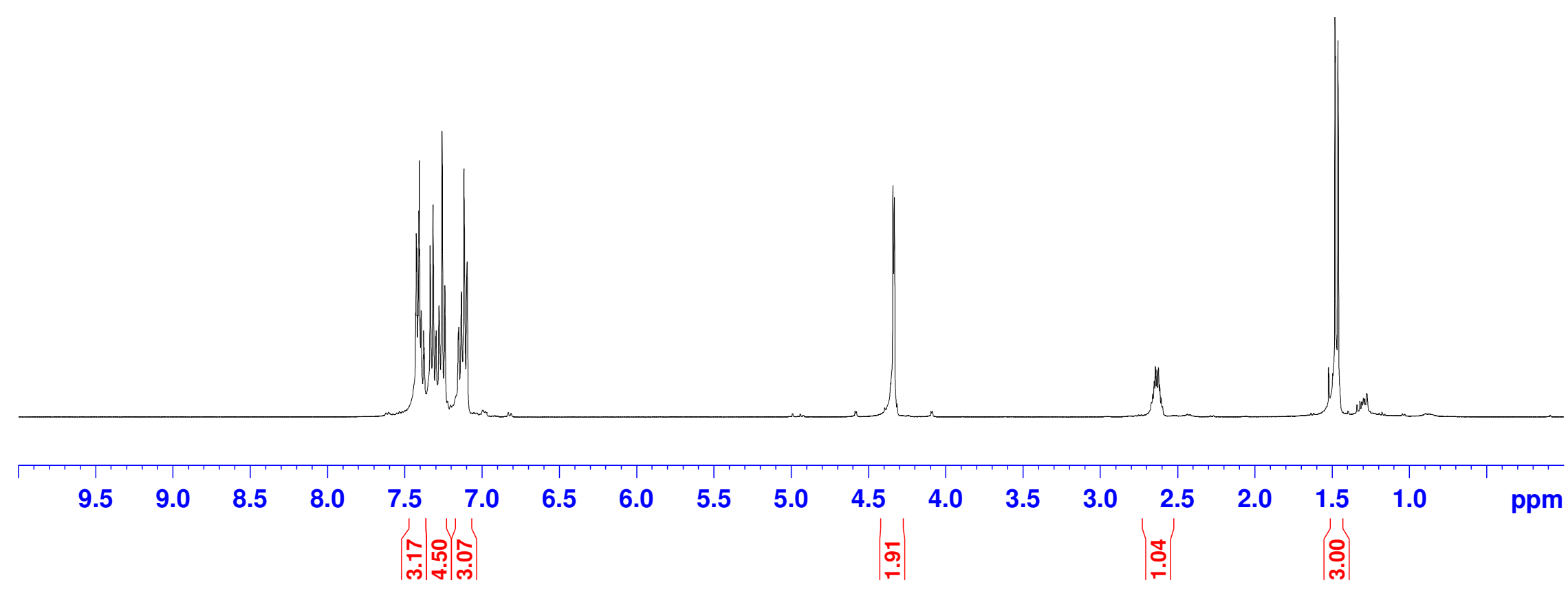



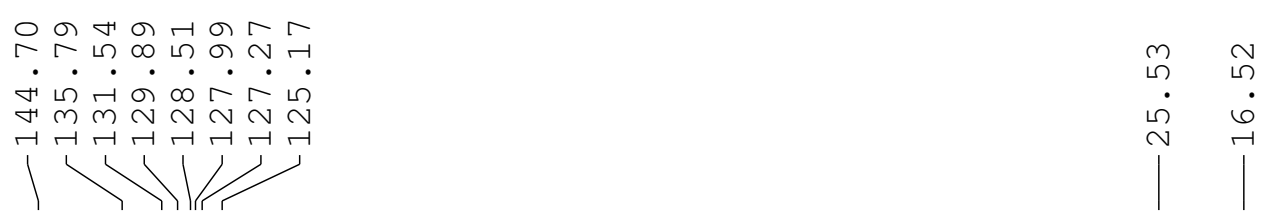<smiles>CC([SiH2]c1ccccc1)c1ccccc1</smiles>

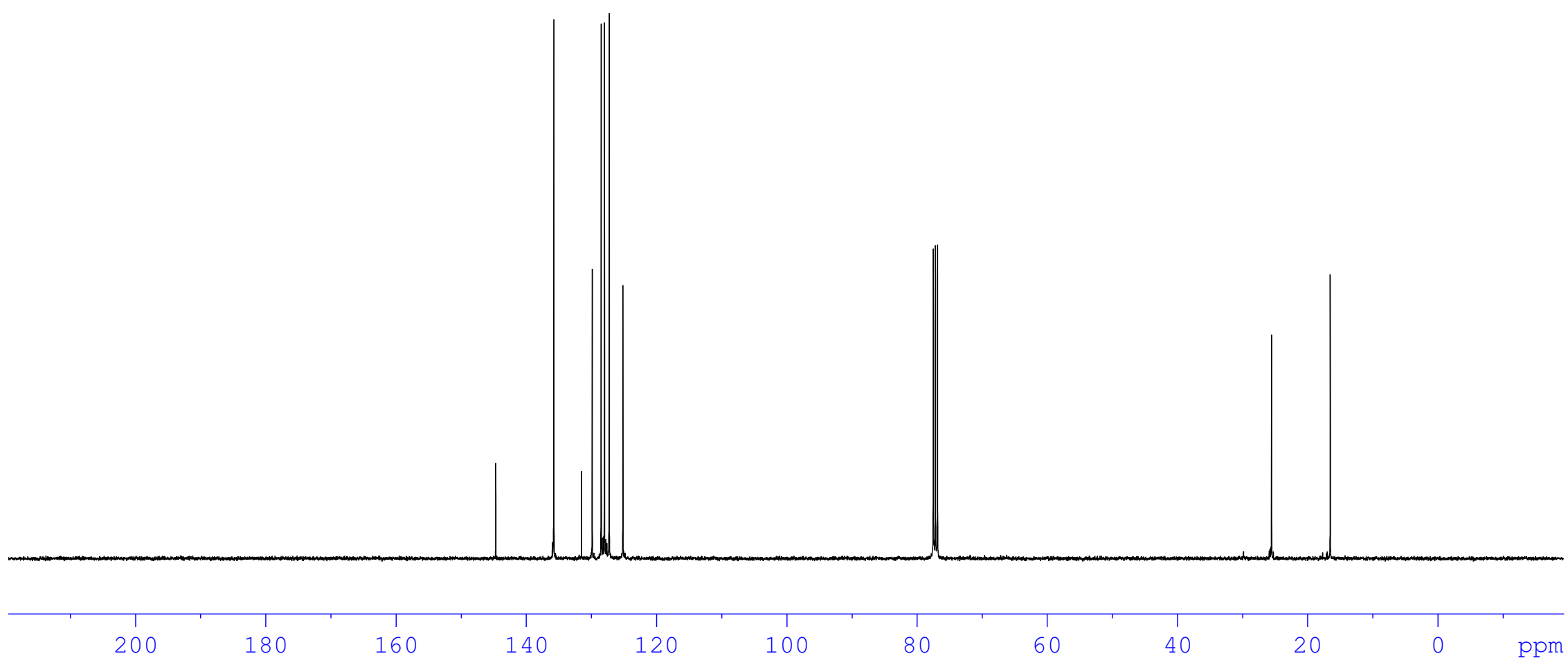




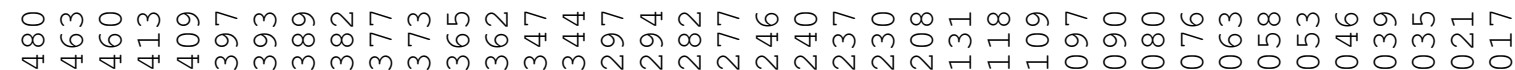

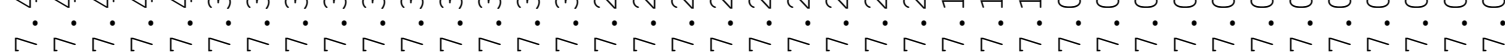

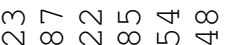

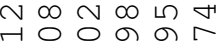
$\dot{\sim} \dot{\sim} \dot{\dot{H}} \dot{\vec{r}}$ 1/

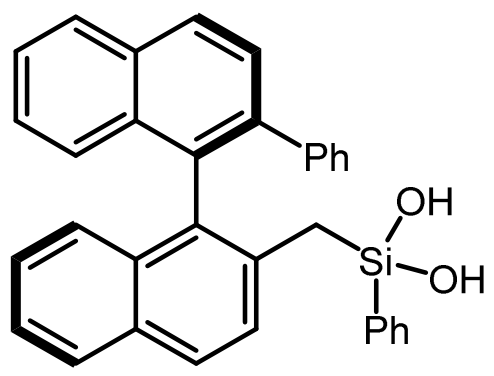

5

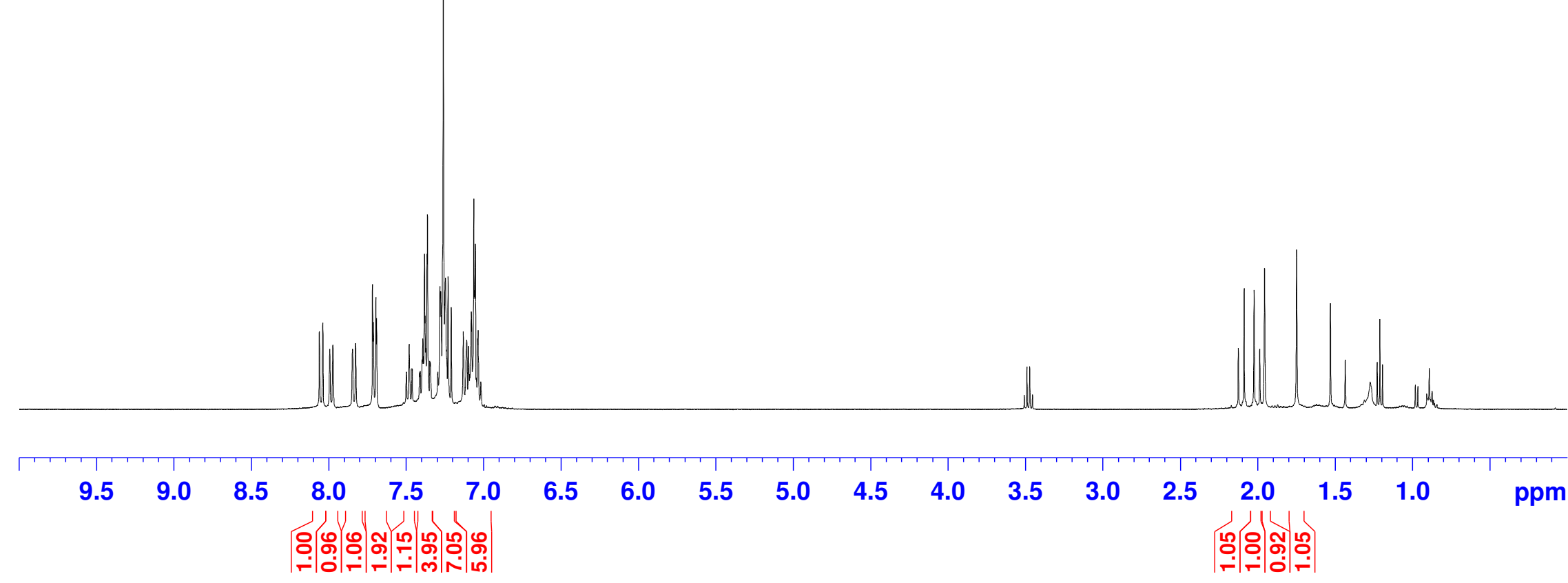


œ0

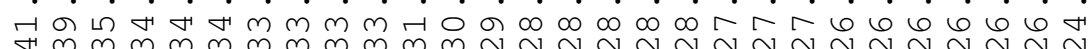

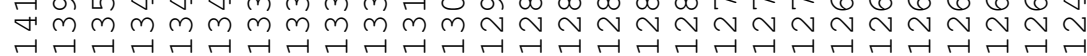

(1)

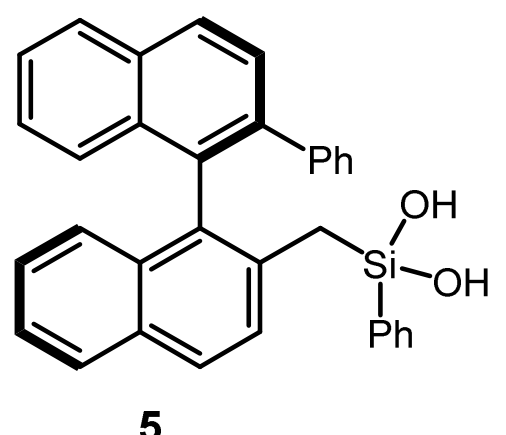

5

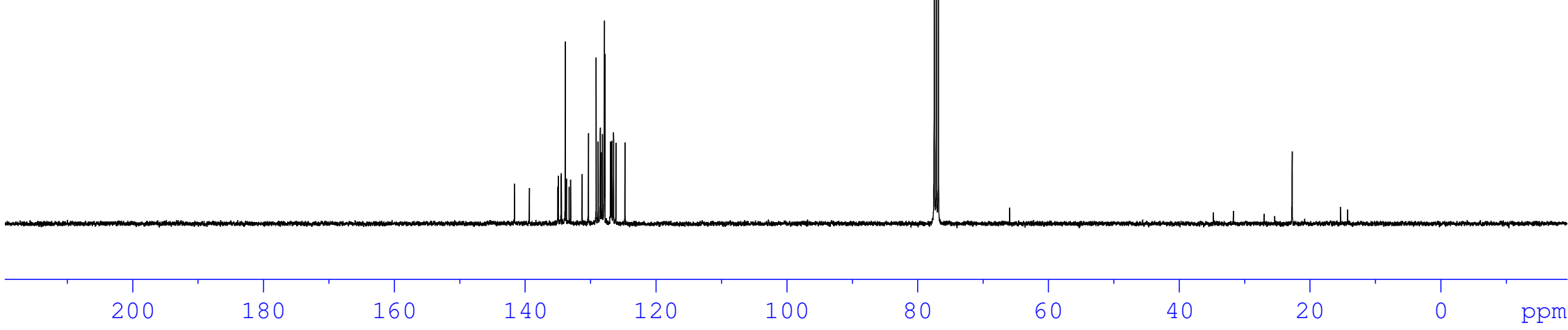




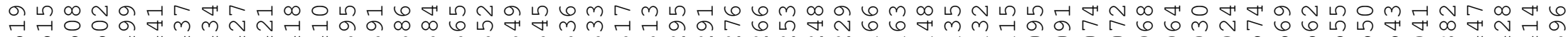

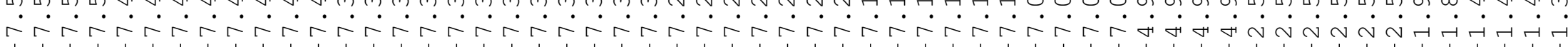

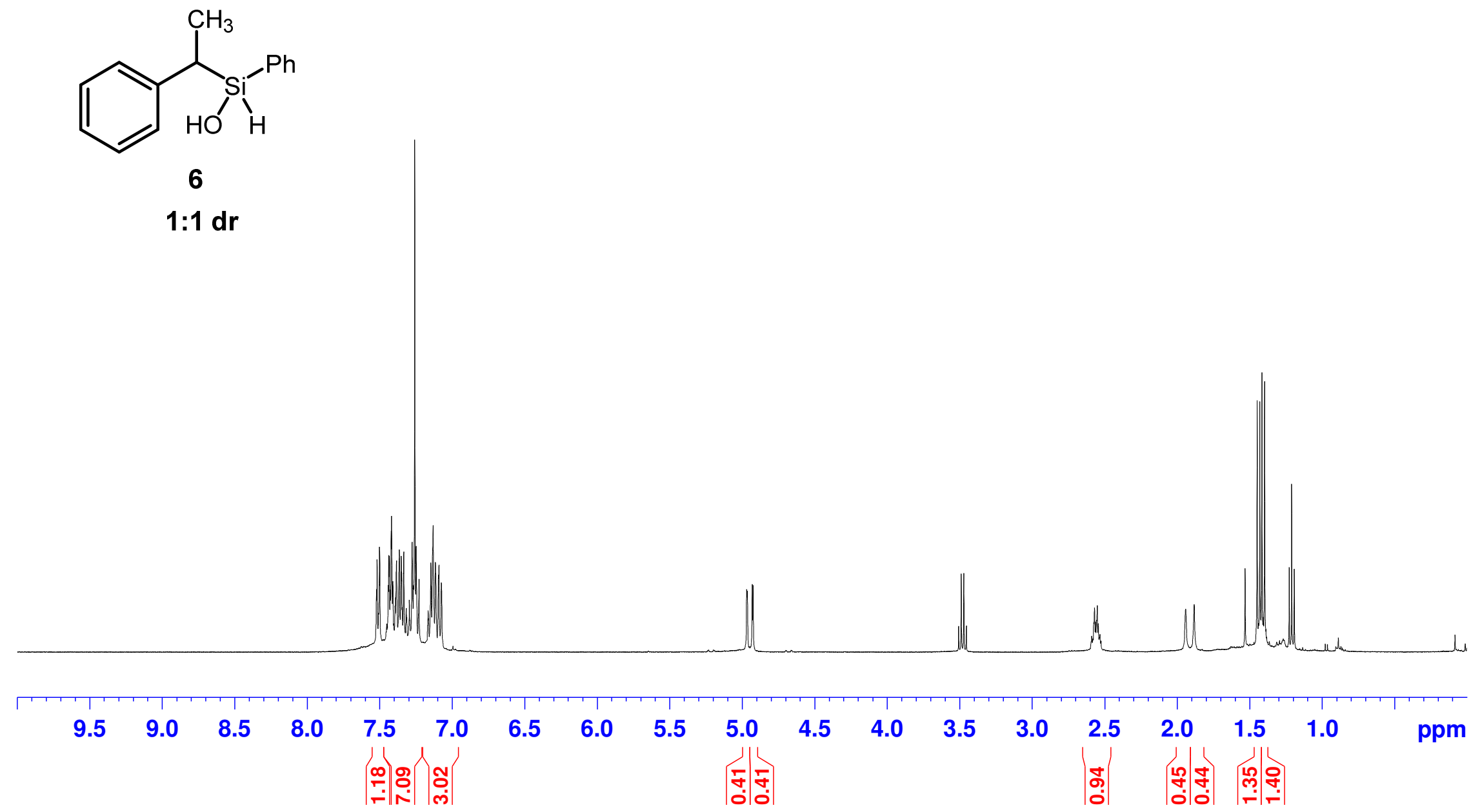



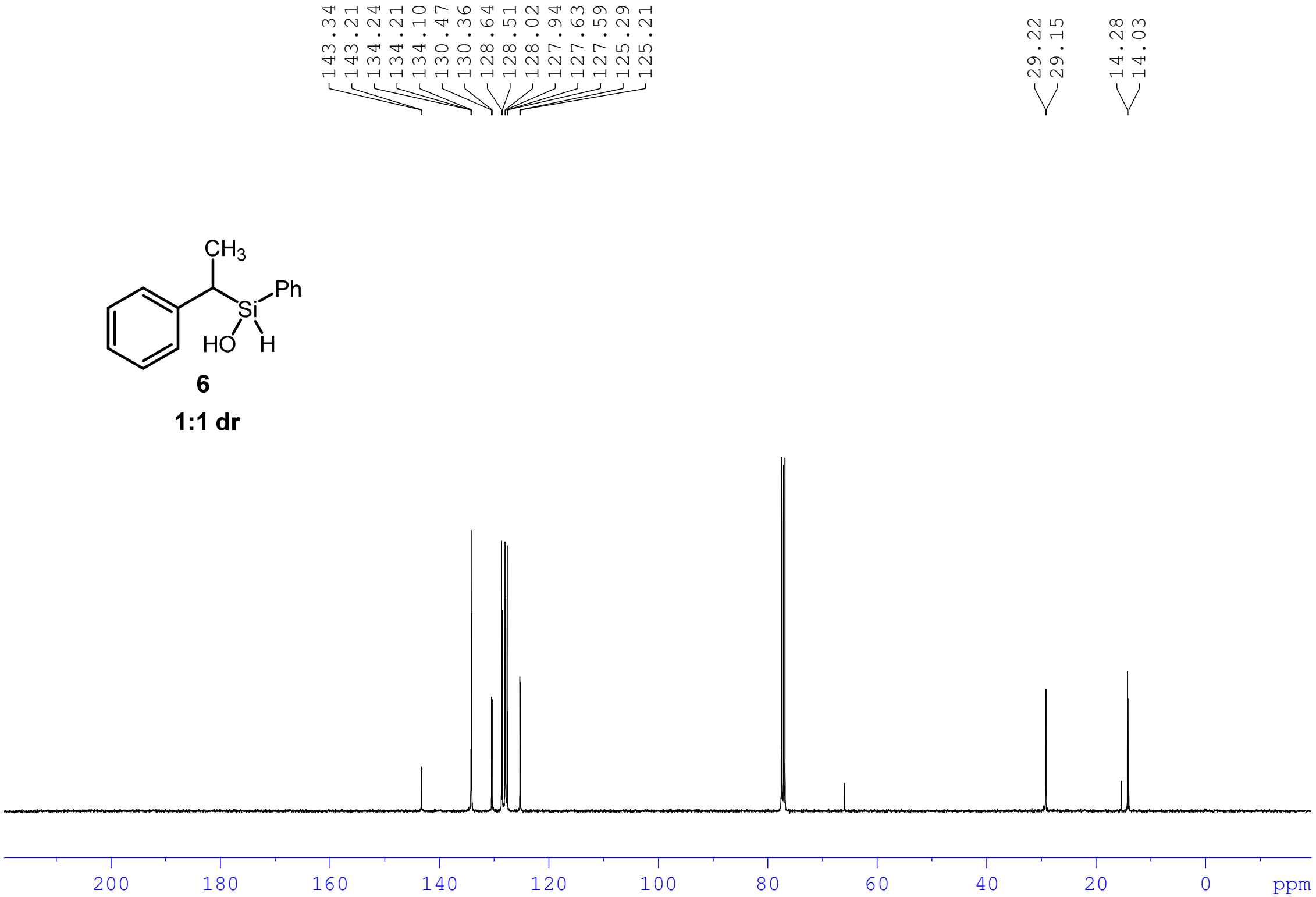